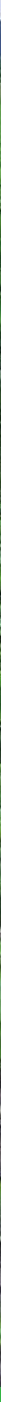

\title{
Effecten van sorghum en mais op bodem en gewas op een verdichte zandgrond
}

Jan van den Akker, Joachim Deru, Joost Sleiderink, Maaike van Agtmaal, Gert-Jan Noij, Marius Heinen 



\title{
Effecten van sorghum en mais op bodem en gewas op een verdichte zandgrond
}

Jan van den Akker $^{1}$, Joachim Deru ${ }^{2 *}$, Joost Sleiderink ${ }^{2}$, Maaike van Agtmaal ${ }^{2}$, Gert-Jan Noij ${ }^{3}$, Marius Heinen ${ }^{1 *}$

\author{
1 Wageningen Environmental Research \\ 2 Louis Bolk Instituut \\ 3 Wageningen Plant Research \\ * Corresponderend auteur
}

Dit onderzoek is uitgevoerd door Wageningen Environmental Research, het Louis Bolk Instituut en Wageningen Plant Research in het kader van onderzoeksprogramma Lumbricus en mede gesubsidieerd door de provincie Noord-Brabant, TKI Deltatechnologie en Brabant Water.

Wageningen Environmental Research

Wageningen, mei 2021

Gereviewd door:

M.J.D. Hack-ten Broeke, teamleider van team Bodem, Water en Landgebruik

Akkoord voor publicatie:

M.J.D. Hack-ten Broeke, teamleider van team Bodem, Water en Landgebruik

Rapport 3081

ISSN 1566-7197 
Van den Akker, J.J.H., J.G.C. Deru, J.W.M. Sleiderink, M. van Agtmaal, I.G.A.M. Noij, M. Heinen, 2021. Effecten van sorghum en mais op bodem en gewas op een verdichte zandgrond. Wageningen, Wageningen Environmental Research, Rapport 3081. 56 blz.; 22 fig.; 26 tab.; 23 ref.

Volgens buitenlands onderzoek is gebleken dat sorghum beter dan mais in staat is om dieper te wortelen in droge, verdichte zandgronden. Omdat sorghum voor Nederland nog een vrij nieuw gewas is, is een proef uitgevoerd in Brabant om na te gaan of sorghum ook hier dieper wortelt dan mais op een verdichte zandgrond. Gegevens zijn verzameld over bodem- en gewasparameters en ook over nitraatresidu aan het eind van het seizoen.

Trefwoorden: beworteling, droge bulkdichtheid, droogte, indringingsweerstand, mais, N-mineraal, Nresidu, sorghum, vochtspanning, voederwaarde

Dit rapport is gratis te downloaden van https://doi.org/10.18174/545414 of op www.wur.nl/environmental-research (ga naar 'Wageningen Environmental Research' in de grijze balk onderaan). Wageningen Environmental Research verstrekt geen gedrukte exemplaren van rapporten.

C. 2021 Wageningen Environmental Research (instituut binnen de rechtspersoon Stichting Wageningen Research), Postbus 47, 6700 AA Wageningen, T 03174807 00, www.wur.nl/environmental-research. Wageningen Environmental Research is onderdeel van Wageningen University \& Research.

- Overname, verveelvoudiging of openbaarmaking van deze uitgave is toegestaan mits met duidelijke bronvermelding.

- Overname, verveelvoudiging of openbaarmaking is niet toegestaan voor commerciële doeleinden en/of geldelijk gewin.

- Overname, verveelvoudiging of openbaarmaking is niet toegestaan voor die gedeelten van deze uitgave waarvan duidelijk is dat de auteursrechten liggen bij derden en/of zijn voorbehouden.

Wageningen Environmental Research aanvaardt geen aansprakelijkheid voor eventuele schade voortvloeiend uit het gebruik van de resultaten van dit onderzoek of de toepassing van de adviezen.

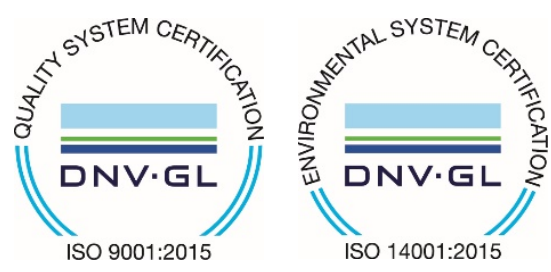

Wageningen Environmental Research werkt sinds 2003 met een ISO 9001 gecertificeerd kwaliteitsmanagementsysteem. In 2006 heeft Wageningen Environmental Research een milieuzorgsysteem geïmplementeerd, gecertificeerd volgens de norm ISO 14001.

Wageningen Environmental Research geeft via ISO 26000 invulling aan haar maatschappelijke verantwoordelijkheid.

Wageningen Environmental Research Rapport 3081 | ISSN 1566-7197

Foto omslag: Jan van Kleef (proeflocatie, 2020-07-08) 


\section{Inhoud}

$\begin{array}{ll}\text { Verantwoording } & 5\end{array}$

$\begin{array}{ll}\text { Woord vooraf } & 7\end{array}$

$\begin{array}{ll}\text { Samenvatting } & 9\end{array}$

$\begin{array}{lr}1 & 11\end{array}$

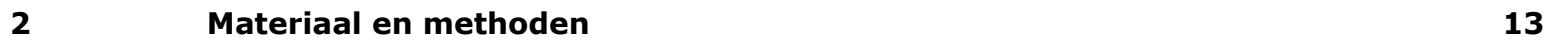

$2.1 \quad$ Proeflocatie, bemesting, behandelingen 13

2.1.1 Uitgangssituatie en bemesting 13

2.1.2 Proefveld en behandelingen 13

2.1.3 Zaaien, onkruidbeheersing 14

2.2 Bodem en meteorologie 14

2.2.1 Bodem 14

2.2.2 Weersgegevens 16

2.2.3 Drukhoogte en grondwaterstand 16

2.2.4 Indringingsweerstand 16

2.2.5 Droge bulkdichtheid 16

2.2.6 Gravimetrisch watergehalte 16

2.3 Gewasmetingen 16

2.3.1 Overzicht 16

2.3.2 Bovengrondse metingen 17

$\begin{array}{ll}2.3 .3 \text { Beworteling } & 17\end{array}$

2.3.4 Visuele bodemstructuurbeoordeling 18

$\begin{array}{lll}2.4 & \text { Nitraat } & 18\end{array}$

$\begin{array}{llr}2.5 & \text { Statistische analyse } & 18\end{array}$

$3 \quad$ Resultaten en discussie $r$

$\begin{array}{lll}3.1 & \text { Meteorologie } & 19\end{array}$

3.2 Bodem 20

3.2.1 Waterretentie en doorlatendheid bij verzadiging 20

$\begin{array}{ll}3.2 .2 \text { Indringingsweerstand } & 21\end{array}$

3.2.3 Droge bulkdichtheid $\quad 22$

3.2.4 Drukhoogte en grondwaterstand $\quad 23$

3.2.5 Watergehalte voor- en najaar $\quad 29$

3.3 Gewas $\quad 29$

3.3.1 Bovengrondse opbrengst $\quad 29$

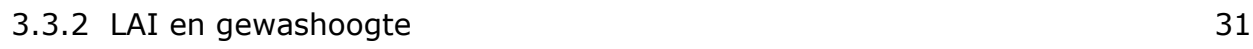

3.3.3 Wortelmetingen $\quad 35$

3.3.4 Bodemstructuur en beworteling: visuele beoordeling 37

$\begin{array}{lll}3.4 & \text { Nitraat } & 37\end{array}$

$\begin{array}{ll}3.4 .1 \text { Voorjaar } & 37\end{array}$

$\begin{array}{ll}3.4 .2 \text { Najaar } & 37\end{array}$

$4 \quad$ Algemene discussie, conclusie en aanbevelingen $\quad 41$

$\begin{array}{lll}4.1 & \text { Algemene discussie } & 41\end{array}$

$\begin{array}{lll}4.2 & \text { Conclusies } & 46\end{array}$

$\begin{array}{lll}4.3 & \text { Aanbevelingen } & 47\end{array}$ 
Bijlage 2 Verkennende proef afbraak van wortels en stoppels van mais en sorghum

Bijlage 3 Waterretentie- en doorlatendheidskarakteristieken 


\section{Verantwoording}

Rapport: 3081

Projectnummer: 5200043670

Wageningen Environmental Research (WENR) hecht grote waarde aan de kwaliteit van zijn eindproducten. Een review van de rapporten op wetenschappelijke kwaliteit door een referent maakt standaard onderdeel uit van ons kwaliteitsbeleid.

Akkoord referent die het rapport heeft beoordeeld,

functie: $\quad$ Teamleider Bodem Water en Landgebruik

naam: M.J.D. Hack-ten Broeke

datum: 09-04-2021

Akkoord teamleider voor de inhoud,

naam: M.J.D. Hack-ten Broeke

datum: 09-04-2021 


\section{Woord vooraf}

In april 2016 heeft ZLTO mede namens de uitvoerende partijen Wageningen Environmental Research (WENR) en het Louis Bolk Instituut (LBI) subsidie aangevraagd bij de provincie Noord-Brabant voor het onderzoeksproject getiteld 'Zuiniger met water in de melkveehouderij door de teelt van sorghum' in het kader van de 'Subsidieregeling provinciaal milieu- en waterplan Noord-Brabant, §2 Klimaatrobuuste zoetwatervoorziening hoge zandgronden overige doelgroepen', en geregistreerd onder het kenmerk C2189542/4072798. Dit rapport dient als de eindrapportage voor de verleende subsidie onder deze subsidieregeling. Het project werd ook ondergebracht in en medegefinancierd door het onderzoeksprogramma Lumbricus (zie hieronder). Wij danken Johan Elshof en Aniek de Jong (ZLTO) voor de intermediair-rol in het aanvragen van de subsidie bij de provincie Noord-Brabant en de opdrachtverlening aan WENR en LBI voor de uitvoering van de gewas- en bodemmetingen. Aanvullend op dit projectvoorstel is een extra deelonderzoek over stikstofresiduen toegevoegd dat werd gefinancierd door TKI Deltatechnologie en Brabant Water (contactpersoon Sandra Verheijden) en werd uitgevoerd door Wageningen Plant Research.

Het onderzoek dat in dit rapport is beschreven, maakte onderdeel uit van het thema 'Bewuste Bodem' van het onderzoeksprogramma Lumbricus (looptijd 2016-2020). Lumbricus is een samenwerkingsprogramma met onderzoeksinstellingen en regionale partijen, waarin doelstellingen met betrekking tot waterkwaliteit, zoetwatervoorziening, bodembeheer, klimaatadaptatie en waterveiligheid samenkomen. Kern van het programma Lumbricus is het ontwikkelen en implementeren van een klimaatrobuust bodem- en watersysteem door het op stroomgebiedsniveau geïntegreerd toepassen van innovatieve matregelen op het gebied van bodem, ondergrond en water. Het Lumbricus-thema 'Bewuste Bodem' richt zich op de bodem als sleutel in vocht- en nutriëntenvoorziening voor landbouw en natuur en op een duurzaam bodem- en waterbeheer voor een gezonde bodem in relatie tot gebruiksfuncties. Het thema richt zich met name op de effectiviteit van hydrologische en bodemmaatregelen op perceelniveau en de verbetering van modellen om de effectiviteit te kunnen beoordelen. Lumbricus bestaat uit een consortium van partijen zijnde Waterschap Vechtstromen, Waterschap Aa en Maas, Waterschap Limburg, STOWA, Universiteit Twente, Radboud Universiteit, Wageningen University departement Omgevingswetenschappen, Wageningen Environmental Research, KWR Watercycle Research Institute, Deltares, KnowH2O, FutureWater en het Louis Bolk Instituut.

Speciale dank aan agrariër G. Hol voor het beschikbaar stellen van een deel van zijn perceel en de bereidheid om grondbewerking en gewasmanagement ter plaatse aan te passen aan de proef.

Wij danken de bijdrage tijdens het veldonderzoek en dataverwerking van: Jan van Kleef (WENR), Willy de Groot (WENR), Wilma Jans (WENR), Ben Rutgers (WPR), Harry Verstegen (WPR), Nick van Eekeren (LBI), Stijn van de Goor (LBI), Pieter Struyk (LBI) Riekje Bruinenberg (LBI), Hans Dullaert (LBI), René Groenen, Teun Luijten. 


\section{Samenvatting}

Voor een klimaatrobuuste zoetwatervoorziening is het van belang om ruwvoerteeltsystemen te ontwikkelen die zuinig met water omgaan en goed bestand zijn tegen langere droogteperioden. Een factor die deze zuinige omgang met water in de weg kan zitten, is bodemverdichting. Hierdoor kunnen de infiltratie- en wateropslagcapaciteit van de bodem en de bewortelingsdiepte beperkt worden. Ook de benutting van nutriënten kan hieronder lijden, waardoor meer uit- en afspoeling optreedt met negatieve gevolgen voor de kwaliteit van grond- en oppervlaktewater.

Bodemverdichting komt relatief vaak voor op percelen waar continu mais geteeld wordt. Sorghum zou een alternatief voor mais kunnen zijn, omdat er aanwijzingen zijn dat het intensiever en dieper wortelt, de bodemstructuur verbetert en verdichting gedeeltelijk opheft. Als dat zo is, zal het naar verwachting ook efficiënter nutriënten op kunnen nemen en minder uitspoeling veroorzaken. In een vruchtwisseling met sorghum zou mais wellicht ook kunnen profiteren van het herstel van de bodemstructuur door sorghum. Daarnaast is sorghum in staat meer biomassa te produceren per eenheid water en kan het de korrelzetting uitstellen in tijden van droogte, waardoor de opbrengst minder onder droogte lijdt.

Het doel van dit onderzoek was om na te gaan of deze claims ook gelden voor de nieuwe sorghumrassen die perspectief bieden voor de Nederlandse veehouderij op verdichte, droogtegevoelige zandgrond met een laag organische stofgehalte.

\section{Bodemfysica, hydrologie en beworteling}

Uit de bodemfysische metingen op het gekozen proefveld is gebleken dat de ondergrond met dichtheden van 1,67 tot $1,69 \mathrm{~g} \mathrm{~cm}^{-3}$ en een indringingsweerstand van meer dan $3 \mathrm{MPa}$ vanaf een diepte van 35-40 cm -mv inderdaad sterk verdicht is. Daarnaast was er in alle proefjaren (2017-2020) sprake van een neerslagtekort tijdens het groeiseizoen. De bodem bleek echter - door een hogere grondwaterstand dan verwacht (Gt III) - feitelijk minder droogtegevoelig. Ook lieten de gemeten doorlatendheden en de snelle reacties van de grondwaterstand op regenval zien dat de verdichting beneden $35 \mathrm{~cm}$ geen belemmering voor waterinfiltratie naar de ondergrond vormde. In 2017-2019 werden geen verschillen in vochtspanningen waargenomen tussen de behandelingen en bleek er voldoende water beneden de wortelzone aanwezig met eventuele aanvulling door capillaire werking. Desondanks heeft de snijmais in de droge jaren 2018, 2019 en 2020 niet echt van het water in de ondergrond kunnen profiteren door een te ondiepe beworteling. Vooral in het droge jaar 2018 had de sorghum (ras: C7) zich kunnen bewijzen, maar ook toen drongen de sorghumwortels niet in de verdichte ondergrond. Uit de waarnemingen met tensiometers op $80 \mathrm{~cm}$ diepte bleek dan ook dat sorghum niet dieper water onttrok dan mais. In 2020 onttrok sorghum structuurtype (ras: Suzy) wél meer water uit de bouwvoor en op $50 \mathrm{~cm}$ diepte dan sorghum graantype C7 en snijmais, hoewel de bodem daaronder niet verder uitdroogde.

De sorghum structuurtypes (rassen: Piper en Suzy) hadden in sommige diepere bodemlagen (30-50 cm -mv) een hogere wortelmassa en/of worteldichtheid dan mais. In 2017 wortelde sorghum Piper ook dieper dan de verdichte laag vanaf $30 \mathrm{~cm}$ diepte. Sorghum graantypes C1 en C7 vertoonden beneden $10 \mathrm{~cm}$ diepte vergelijkbare beworteling als mais. Een hoger aandeel kruimels in de laag 0-45 cm -mv in 2017 onder sorghum Piper duidde op een verbetering van de bodemstructuur en kon deels aan de intensieve beworteling en deels aan de kortere rijafstand van sorghum Piper ten opzichte van de andere behandelingen toegeschreven worden. Het ontbreken van grote verschillen in beworteling op diepte tussen mais en sorghum wordt verklaard door 1) een hoge ondergrondverdichting, 2) genoeg vocht beschikbaar in de bouwvoor, 3) rasverschillen binnen de sorghum.

\section{Gewasgroei}

Mais had consistent een hogere droge stofopbrengst en over het algemeen ook een hogere voederwaarde en stikstofopbrengst dan de geteste sorghumrassen, ook na de droge groeiseizoenen 
van 2018 en 2019. Dit lijkt tegenstrijdig met andere studies, waarin sorghum droogteresistenter bleek dan mais. Er werden echter verschillen gevonden tussen sorghum rastypes in deze vergelijkende studie. De rassenkeuze kan in onze studie dus van invloed geweest zijn op de mate van droogtestress van sorghum. Daarnaast spelen de bodemtemperatuur en de droogte van het zaaibed een belangrijke rol. Sorghum heeft een bodemtemperatuur van minstens $15{ }^{\circ} \mathrm{C}$ nodig, terwijl bij snijmais $12{ }^{\circ} \mathrm{C}$ voldoende is. Daarnaast heeft sorghum door de veel kleinere zaadjes dan snijmais eerder last van een droog zaaibed. De actuele droogte en lage (bodem)temperaturen tijdens de vier groeiseizoenen hebben invloed gehad op de groei van sorghum ten opzichte van mais. De veredeling op koudetolerantie is bij sorghum nog niet zover als bij mais. Bovendien bevat het dikkere zaad van mais meer reserves. Met name 2019 en 2020 waren het begin van de groeiperiode droog en koud, wat de beginontwikkeling van sorghum ten opzichte van mais een grote achterstand heeft gegeven. Door de tegenvallende productie van sorghum had dit gewas een lagere behoefte voor water, waardoor waarschijnlijk alleen in 2018 droogtestress later in het groeiseizoen is opgetreden, omdat toen de beworteling toch niet in de ondergrond bleek te kunnen dringen. Verder hadden de sorghum structuurtypes Piper en Suzy een zeer lage zetmeelopbrengst en leek er een klein, maar niet significant positief effect te zijn van een sorghum-voorvrucht op de opbrengst van mais.

\section{Nitraat}

Het effect van de behandelingen continu sorghum (ras: C7) en continu mais op de overgebleven hoeveelheid nitraat in de laag 0-90 cm -mv (NR) verschilde tussen de jaren; bij sorghum bleef in drie van de vier jaren en gemiddeld over de jaren minder NR achter, maar dit verschil was maar in één jaar significant. Tussen de vier behandelingen werden in 2017 en 2020 geen significante verschillen in NR gevonden. Er waren ook geen significante verschillen tussen behandelingen in de verdeling van het nitraat over de drie lagen van $30 \mathrm{~cm}$.

\section{Resumé}

Omdat uit buitenlands onderzoek was gebleken dat sorghumwortels kunnen indringen in sterk verdichte bodemlagen, is op een locatie in Brabant met een sterk verdichte ondergrond - beginnend op circa $35 \mathrm{~cm}$ diepte - een proef uitgevoerd waarin de beworteling en gewasontwikkeling van sorghum en mais onderling is vergeleken (in viervoud) gedurende de groeiseizoenen 2017-2020. Hiervoor werden sorghumrassen gebruikt die recentelijk ontwikkeld zijn voor Nederlandse omstandigheden. Naast gewasmetingen zijn ook metingen van bodemvocht(spanning) en nitraatresidu in de bodem uitgevoerd.

De drogestofopbrengst van sorghum was lager dan van mais. Er was geen duidelijk verschil in bewortelingsdiepte tussen sorghum en mais. Het is duidelijk dat de bewortelingsdiepte van de snijmais werd beperkt door de te dichte ondergrond. De tragere groei van sorghum is zeer waarschijnlijk toe te schrijven aan de relatief koude en droge omstandigheden tijdens het zaaien en de startontwikkeling, in combinatie met genetische verschillen tussen mais en sorghum en tussen sorghumrassen. Ondanks de vertraagde bovengrondse groei en verdere ontwikkeling was de beworteling van sorghum niet minder dan die van mais, maar de gebruikte sorghumtypes met een hoge voederwaarde wortelden ook niet dieper dan mais. Tevens was er door de slechte groei van de sorghum in de meeste jaren voldoende neerslag en bodemvocht in de bouwvoor, waardoor er ook minder noodzaak was om dieper te wortelen. Alleen in 2018 waren de omstandigheden zodanig dat een diepere beworteling van de sorghum kon worden verwacht, maar dit is niet waargenomen bij sorghum C7. Er is geen duidelijk verschil gevonden in het uitspoelingsrisico van nitraat tussen beide gewassen.

Deze resultaten lijken tegenstrijdig met rapportages uit buitenlands onderzoek. Dit wordt toegeschreven aan verschillen in sorghumrassen, verschillen in bodemstructuur en potentiële bewortelbaarheid, vochtvoorziening uit de ondergrond en verschillen in klimatologische omstandigheden, met name bij de start van groei startontwikkeling.

Een vervolgonderzoek zou daarom meer sorghumrassen en rastypes moeten bevatten. Het ligt daarnaast voor de hand om een dergelijke proef te herhalen op een zandgrond met verdichte ondergrond waar vaststaat dat het grondwater diep zit. Voor een proef is het daarnaast aan te raden om de start van de groei goed te begeleiden, bijvoorbeeld via gerichte beregening. In de veredeling van sorghum zou verbeteren van koudetolerantie en startontwikkeling prioriteit moeten krijgen. 


\section{$1 \quad$ Inleiding}

Met het oog op een klimaatrobuuste zoetwatervoorziening is het belangrijk om zuinig om te gaan met water. De ruwvoerteelt voor melkvee is een grote waterverbruiker. Daarom is het nodig ruwvoerteeltsystemen te ontwikkelen die beter bestand zijn tegen droogte en zuiniger omgaan met water. Een belangrijk knelpunt hierbij is de bodemverdichting die over de afgelopen decennia is ontstaan als gevolg van mechanisatie, waardoor de infiltratiecapaciteit afneemt en wortels van ruwvoergewassen moeilijker in de bodem kunnen doordringen. De beperkte infiltratiecapaciteit en ondiepere beworteling verkleint de waterbuffer voor het opvangen van droge perioden. Bovendien kan het gewas minder efficiënt omgaan met nutriënten in een verdichte bodem, met uitspoeling als gevolg. Ook spoelt er bij felle buien meer water oppervlakkig af, omdat het water niet in de grond kan doordringen. Gevolgen hiervan zijn meer of grotere afvoerpieken en extra belasting van oppervlaktewater met nutriënten en gewasbeschermingsmiddelen.

Bodemverdichting speelt extra sterk op percelen waar continu mais wordt geteeld. Continuteelt van mais komt veel voor op de hoge zandgronden en heeft als risico opbrengstderving door verlies van organische stof, opbouw van bodemgebonden ziekten en verdichting. De vraag is of er een alternatief gewas in de teeltrotatie op een melkveebedrijf opgenomen kan worden dat zorgt voor bodemverbetering en tevens als veevoer gebruikt kan worden.

Sorghum is het vijfde graangewas ter wereld. In Amerika en Afrika wordt het veel geteeld op percelen die te droog zijn voor mais. In Frankrijk wordt het als voedergewas geteeld en in Zuid-Duitsland is het populair voor biovergisters. Sorghum kent twee typen: een 'structuurtype' (Sorghum sudanense), dat vooral stengel en blad vormt, meerjarig is en na maaien verder groeit, en een 'graantype' of ook 'zetmeeltype' genoemd (Sorghum bicolor), dat meer pluim met zetmeelrijk graan produceert, en minder snel opnieuw verder groeit na maaien. Verder zijn er door kruising verschillende tussenvarianten.

Sorghum is een gewas dat qua groeiwijze en teelt lijkt op mais, maar mogelijk ook een aantal voordelen kent. Het gewas kan beter tegen droogte doordat het dieper en intensiever wortelt en daardoor in droge omstandigheden meer water uit de ondergrond op kan nemen (Schittenhelm \& Schroetter, 2014). Ook blijkt dat sorghum graantypes onder droge omstandigheden meer biomassa dan mais kunnen produceren per hoeveelheid water (Farré \& Faci, 2006). Zoete sorghumtypes gaan nog efficiënter met water om dan graantypes, en ook onder natte omstandigheden kunnen ze efficiënter zijn met water dan mais (Steduto et al., 1997; Zegada-Lizarazu et al., 2012). Onder droge omstandigheden is de potentieel haalbare drogestofopbrengst van sorghum daarom ook hoger dan die van mais, hoewel dit verschil voor graan- en zoete sorghumtypes groter lijkt dan voor structuurtypes (Farré \& Faci, 2006; Zegada-Lizarazu et al., 2012; Schittenhelm \& Schroetter, 2014). Het gewas kan bovendien in droge perioden de bloei en korrelzetting uitstellen (Wright et al., 1983), waardoor ook in droge jaren voldoende voederwaarde kan worden bereikt. Door de diepere en intensievere beworteling worden niet alleen water en nutriënten efficiënter opgenomen (Van Agtmaal et al., 2020), maar ook de bodem verbeterd (o.a. door het opheffen van verdichting) waarvan ook andere gewassen, o.a. mais, in de vruchtwisseling kunnen profiteren.

Door bodemverbetering en een lagere waterbehoefte lopen melkveebedrijven op droge zandgronden minder risico op droogtestress door klimaatverandering. Sorghum zou zo kunnen bijdragen aan een veerkrachtigere bedrijfsvoering. Het gewas heeft bovendien mogelijk een sanerend effect op bodemgebonden pestfauna, zoals pathogene nematoden (Djian-Caporalino et al., 2019) of de quarantaineplaag van de maiswortelboorder (Branson et al., 1969), doordat sorghum blauwzuur kan produceren. Daarnaast heeft sorghum een onderdrukkend effect op onkruid, te danken aan de stof sorgoleon, waarvan een volgend gewas ook nog kan profiteren (Einhellig \& Rasmussen, 1989; Farooq et al., 2020). Hierdoor zou mais in vruchtwisseling met sorghum meer kunnen opbrengen dan in continuteelt. Het gewas wordt in de VS aanbevolen als droogteresistente bodemverbeteraar. In Zuid- 
Frankrijk en Zuid-Duitsland wordt sorghum, net zoals snijmais, geteeld voor veevoer. De daar gebruikte rassen rijpen onder de Nederlandse omstandigheden echter niet af en zijn daarom niet interessant voor de melkveehouderij in Nederland.

Door recente, gerichte veredeling ${ }^{1}$ op koudetolerantie in het voorjaar en goede afrijping onder Nederlandse omstandigheden zijn er nu nieuwe gewaslijnen en rassen beschikbaar die hier kunnen worden geteeld voor een snijmaisachtig product met voldoende zetmeel. In de periode 2013 en 2014 is er in Nederland een eerste ervaring opgedaan door een melkveehouder met deze rassen in het project Bufferboeren (Van Eekeren et al., 2015). Sindsdien vindt nog verdere ontwikkeling via veredeling plaats en zijn verschillende onafhankelijke rassenproeven uitgevoerd (o.a. De Wit \& Van Eekeren, 2015; Van de Goor et al., 2017, Deru et al., 2018, Van Agtmaal et al., 2019; 2020). Dit zal naar verwachting leiden tot rassen waarvan op grotere schaal zaad beschikbaar is voor de Nederlandse melkveehouderij. De eerste rassen voor het Noord-Europese klimaat zijn sinds 2021 geregistreerd en (beperkt) op de markt. Het gaat om Voyenn en Vilomene van DSV en HD7 en HD19 van Hoeve Dierkensteen. Hiermee ontstaat perspectief voor introductie van sorghum in Nederland, als alternatief of aanvulling op snijmais.

Voor een goede beoordeling van het perspectief van een nieuw ruwvoergewas op droogtegevoelige zandgronden, waar zich ook intrekgebieden voor drinkwaterwinning bevinden, is het risico op nitraatuitspoeling van belang. Op grond van de hierboven genoemde aanwijzingen dat sorghum intensiever wortelt dan mais en beter om kan gaan met droogte, rijst de vraag of dat dan ook leidt tot een verlaagde kans op nitraatuitspoeling bij de teelt van sorghum in vergelijking met de teelt van mais. Het risico op nitraatuitspoeling kan worden geschat op grond van het zogenaamde Nitraat Residu (NR), de hoeveelheid nitraat die aan het eind van het groeiseizoen (1 okt-15 nov) aanwezig is in de bodemlaag $0-90 \mathrm{~cm}$.

\section{Doel}

Doel van dit onderzoek is om na te gaan of de geclaimde voordelen van sorghum ten opzichte van mais, zoals minder droogtegevoelig en beregeningsbehoeftig, een hogere water- en nutriëntenefficiëntie, een diepere beworteling en de voordelen in een gewasrotatie met snijmais, ook onder Nederlandse omstandigheden meetbaar zijn. Aanvullend zal op basis van NR-metingen in het bodemprofiel nagegaan worden of sorghum mogelijk ook effect op de nitraatuitspoeling heeft. In dit rapport worden de resultaten van een vierjarige proef op een verdichte droogtegevoelige zandgrond in Noord-Brabant beschreven waarin dit onderzocht is.

\footnotetext{
1 o.a. door Hoeve Dierkensteen in Zeeland en DSV Zaden.
} 


\section{$2 \quad$ Materiaal en methoden}

\subsection{Proeflocatie, bemesting, behandelingen}

\subsubsection{Uitgangssituatie en bemesting}

De proef is uitgevoerd gedurende vier jaar (2017-2020) op een praktijkperceel van een agrariër te Odiliapeel, geselecteerd vanwege de verdichte ploegzool en de droogtegevoelige zandgrond. Het betrof een veldpodzol in leemarm of zwaklemig fijn zand (Hn21) met, naar later bleek, een Gt III. De zwarte laag (A-horizont) is 35-40 cm dik. Het perceel was gelegen binnen Lumbricus proeftuin Zuid (stroomgebied De Raam). In 2016 was het perceel gebruikt voor de teelt van wortels, vanaf 2017 is sorghum geteeld. De bodemanalyse $(0-25 \mathrm{~cm})$ voor de start van de proef gaf relatief lage waardes voor organische stof $(2,7 \%), \mathrm{pH}(4,5), \mathrm{N}$ - en S-leverend vermogen en plant beschikbare $\mathrm{K}$ (Bijlage 1 ). Vanwege de lage $\mathrm{pH}$ is in april 20172 ton kalk per ha over het perceel gestrooid. De lage N-, S- en $\mathrm{K}$-waardes zijn via drijfmest en kunstmest aangevuld als beschreven in Tabel 2-1.

Tabel 2-1 Grondbewerking en bemesting van het proefveld in $2017 \mathrm{t} / \mathrm{m} 2020$.

\begin{tabular}{lllll} 
Management & 2017 & 2018 & 2019 & 2020 \\
Grondbewerking & Ploeg (begin april) & Ploeg (12 mei) & Niet-kerend (half april) & Ploeg (13 mei) \\
\hline Bemesting drijfmest per ha & 28 maart: $25 \mathrm{~m}^{3}$ & $11 \mathrm{mei}: 28 \mathrm{~m}^{3}$ & April: $25 \mathrm{~m}^{3}$ & $7 \mathrm{april}^{2} 25 \mathrm{~m}^{3}$ \\
& $113 \mathrm{~kg} \mathrm{~N}$ totaal & $131 \mathrm{~kg} \mathrm{~N}$ totaal & $119 \mathrm{~kg} \mathrm{~N}$ totaal & $123 \mathrm{~kg} \mathrm{~N}$ totaal \\
\hline Bemesting in de rij per ha & $43 \mathrm{~kg} \mathrm{~N}$ & $34 \mathrm{~kg} \mathrm{~N}$ & $22 \mathrm{~kg} \mathrm{~N}$ & $22 \mathrm{~kg} \mathrm{~N}$ \\
& $27 \mathrm{~kg} \mathrm{SO}$ & $21 \mathrm{~kg} \mathrm{SO}$ & $14 \mathrm{~kg} \mathrm{SO}$ & $14 \mathrm{~kg} \mathrm{SO}_{3}$ \\
\hline Bemesting K60 per ha & $200 \mathrm{~kg}$ & $240 \mathrm{~kg}$ & $100 \mathrm{~kg}$ & -
\end{tabular}

\subsubsection{Proefveld en behandelingen}

Het onderzoek is uitgevoerd in een proefveld van $20 \times 40 \mathrm{~m}$, waarin vier behandelingen in vier herhalingen waren opgenomen in een 'Latin square' design, met een totaal van 16 plots van elk $4,5 \mathrm{x}$ $10 \mathrm{~m}$ (Tabel 2-2; Figuur 2-1). De locaties van de plots waren voor vier jaar vastgelegd om cumulatieve effecten te kunnen meten. De vier behandelingen waren:

- M: mais continu

- S1: drie jaar sorghum (zetmeeltype-ras) gevolgd door een jaar mais in 2020

- S2: vier jaar sorghum (zetmeeltype-ras)

- S3: vier jaar sorghum (structuurtype-ras in jaren 1 en 4 en zetmeeltype-ras in jaren 2 en 3 )

$\mathrm{Na}$ de oogst werd over het hele perceel, inclusief proefveld, een groenbemester gezaaid.

Tabel 2-2 Rassen, zaaidata, oogstdata en plantdichtheid van mais en sorghum per behandeling in $2017 \mathrm{t} / \mathrm{m}$ 2020. Het getal rechts van de ras-naam is de gewenste plantdichtheid voor dat ras in het desbetreffende jaar, in duizend planten per ha.

\begin{tabular}{|c|c|c|c|c|c|c|c|c|}
\hline Behandeling & 2017 & & 2018 & & 2019 & & 2020 & \\
\hline M1: mais * & LG 30.209 & 110 & LG 30.209 & 110 & LG 30.209 & 110 & LG 30.209 & 110 \\
\hline S1: sorghum en mais & $\mathrm{C} 1 * *$ & 275 & $\mathrm{C7}$ & 275 & C7 & 225 & LG 30.209 & 110 \\
\hline S3: sorghum/structuur & Piper & 500 & $\mathrm{C7}$ & 275 & $\mathrm{C7}$ & 225 & Suzy & 225 \\
\hline Zaai- en oogstdatum & $23 / 5-28 / 9$ & & $17 / 5-25 / 9$ & & $17 / 5-7 / 10$ & & $18 / 5-5 / 10$ & \\
\hline
\end{tabular}

${ }^{*}$ Maisras met zeer kort groeiseizoen, kon gelijktijdig met de sorghum gezaaid en geoogst worden.

${ }^{* *}$ Oogst 1 week eerder i.v.m. eerdere afrijping. 
a)
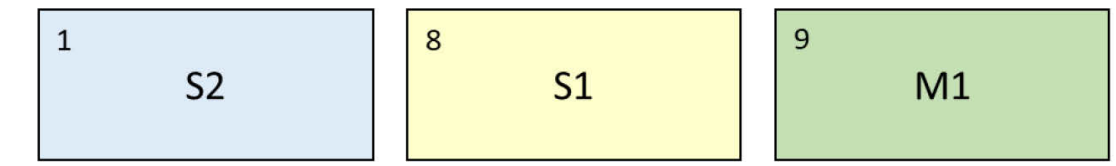

16

S3
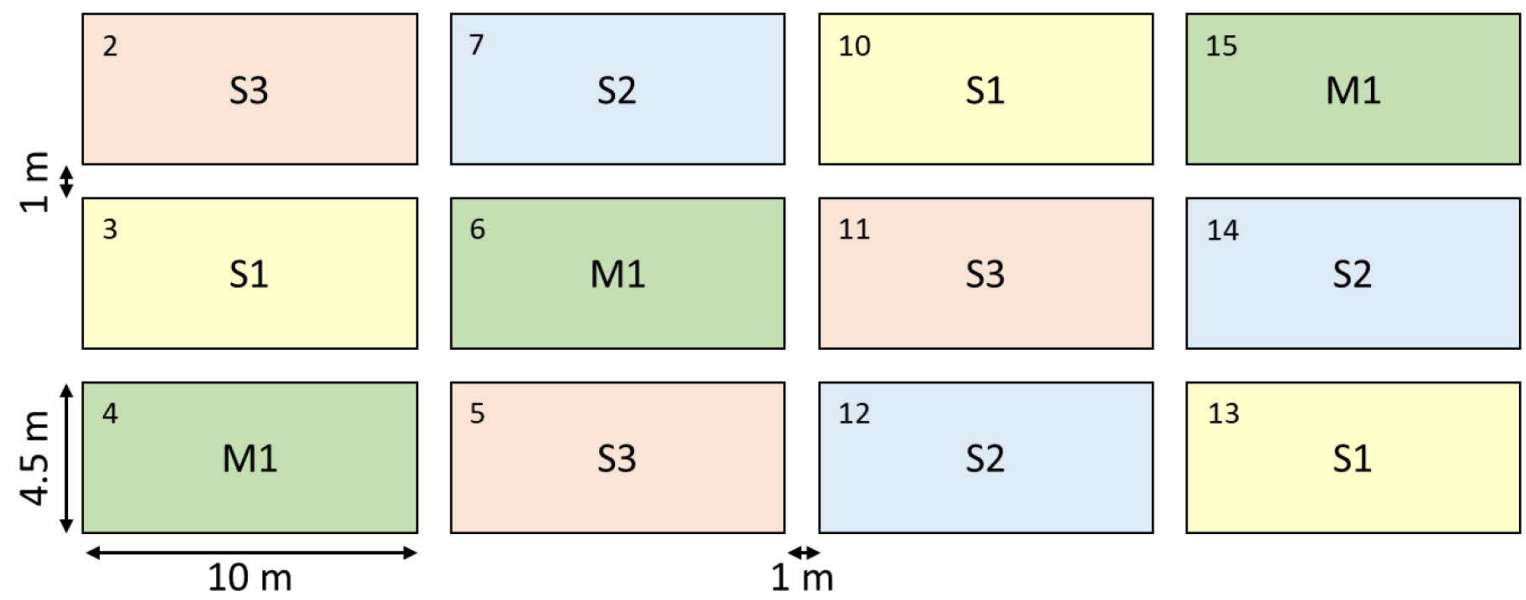

N

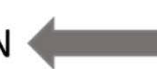

Figuur 2-1 Plattegrond van de 16 proefveldjes (plots) op het proefperceel. Op de plots met code M1 is steeds mais geteeld (ras LG.30.209). Uitgezonderd plots S1 in 2020, is op alle overige plots steeds sorghum geteeld (rassen C7, Piper of Suzy); in 2020 is op plots 51 mais geteeld om de behandeling mais-na-sorghum te kunnen beschouwen (details zie Tabel 2-2).

\subsubsection{Zaaien, onkruidbeheersing}

Het zaaien gebeurde met een precisie-handzaaimachine op een diepte van 2 tot $3 \mathrm{~cm}$ en op rijen met $50 \mathrm{~cm}$ onderlinge afstand, zowel voor mais als sorghum. Ieder plot telde 9 rijen van $10 \mathrm{~m}$ lang. Piper (in 2017) werd echter op $25 \mathrm{~cm}$ gezaaid (18 rijen) vanwege de zeer hoge geadviseerde plantdichtheid. De zaaidichtheid werd bepaald aan de hand van het kiempercentage (kiemtest voorafgaand aan het zaaien met de actuele zaadbatch), de gewenste plantdichtheid (Tabel 2-2) en een onzekerheidsopslag van $15 \%$. Na de kieming werd handmatig gedund om de gewenste plantdichtheid in het veld te verkrijgen.

De mais werd gezaaid met als doel een dichtheid in het veld van 110.000 planten per ha. Sorghum werd in 2017 en 2018 gezaaid voor een dichtheid van 275.000 planten per ha (Piper: 500.000 conform rasadvies). In 2019 en 2020 is de zaaidichtheid verlaagd (225.000 planten per ha) op grond van nieuw inzicht vanuit andere proeven. Onkruidbeheersing werd met de hand uitgevoerd door twee of drie keer in de loop van juni te wieden.

\subsection{Bodem en meteorologie}

\subsubsection{Bodem}

De bodem van de proeflocatie Odiliapeel is volgens de Nederlandse bodemkaart een veldpodzol in leemarm of zwaklemig fijn zand (Hn21). Dit is bevestigd aan de hand van een lokale bodembeschrijving in het najaar van 2017 (Tabel 2-3; Figuur 2-2). De dikte van de A-horizont varieert licht over het perceel (volgens boorbeschrijving in Tabel 2-3 $30 \mathrm{~cm}$, volgens foto's Figuur 2-2 $35 \mathrm{~cm}$ ) en op de overgang A naar BC zien we soms menging van moedermateriaal met bovengrond, wat duidt op diepere grondbewerking in het verleden. De GHG en GLG werden ingeschat op respectievelijk 35 en $85 \mathrm{~cm}-\mathrm{mv}$ (grondwatertrap IIIb) en de bewortelingsdiepte was ingeschat op $30 \mathrm{~cm}$. De gemeten textuurverdeling en organische stofgehaltes (loss-on-ignition methode) voor drie bodemlagen is gegeven in Tabel 2-4. 
Op drie diepten zijn op 4 oktober 2017 in duplo ongestoorde bodemmonsters genomen op dezelfde diepte waaraan de textuurverdeling is bepaald (zie Tabel 2-4). Van deze monsters zijn in het laboratorium de droge bulkdichtheid, waterretentiekarakteristiek ( 5 punten) en de doorlatendheid bij verzadiging bepaald. De porositeit is berekend uit:

$$
P V=1-\rho_{d}\left(\frac{O S}{1.47}+\frac{1-O S}{2.66}\right)
$$

Het luchtgehalte is berekend als porositeit minus het watergehalte; voor $h=-50 \mathrm{~cm}$ is het watergehalte eerst geschat als het gemiddelde van de metingen bij $h=-30 \mathrm{~cm}$ en $h=-70 \mathrm{~cm}$.

Tabel 2-3 Bodemprofielbeschrijving 11 oktober 2017; de gehaltes organische stof en leem zijn veldschattingen.

\begin{tabular}{ll|llll} 
Laag & $\begin{array}{l}\text { Diepte } \\
(\mathrm{cm}-\mathrm{mv})\end{array}$ & Code & $\begin{array}{l}\text { Org, stof } \\
\left(\%, \mathrm{~g} \mathrm{~g}^{-1}\right)\end{array}$ & $\begin{array}{l}\text { Leem } \\
\left(\%, \mathrm{~g} \mathrm{~g}^{-1}\right)\end{array}$ & 9 \\
\hline 1 & $0-30$ & $1 \mathrm{Ap}$ & 3,0 & 7 & 170 \\
\hline 2 & $1 \mathrm{BCg}$ & 0,5 & 7 & 180 \\
\hline 3 & $10-50$ & $1 \mathrm{Cg}$ & 0,1 & 7 & 180 \\
\hline
\end{tabular}
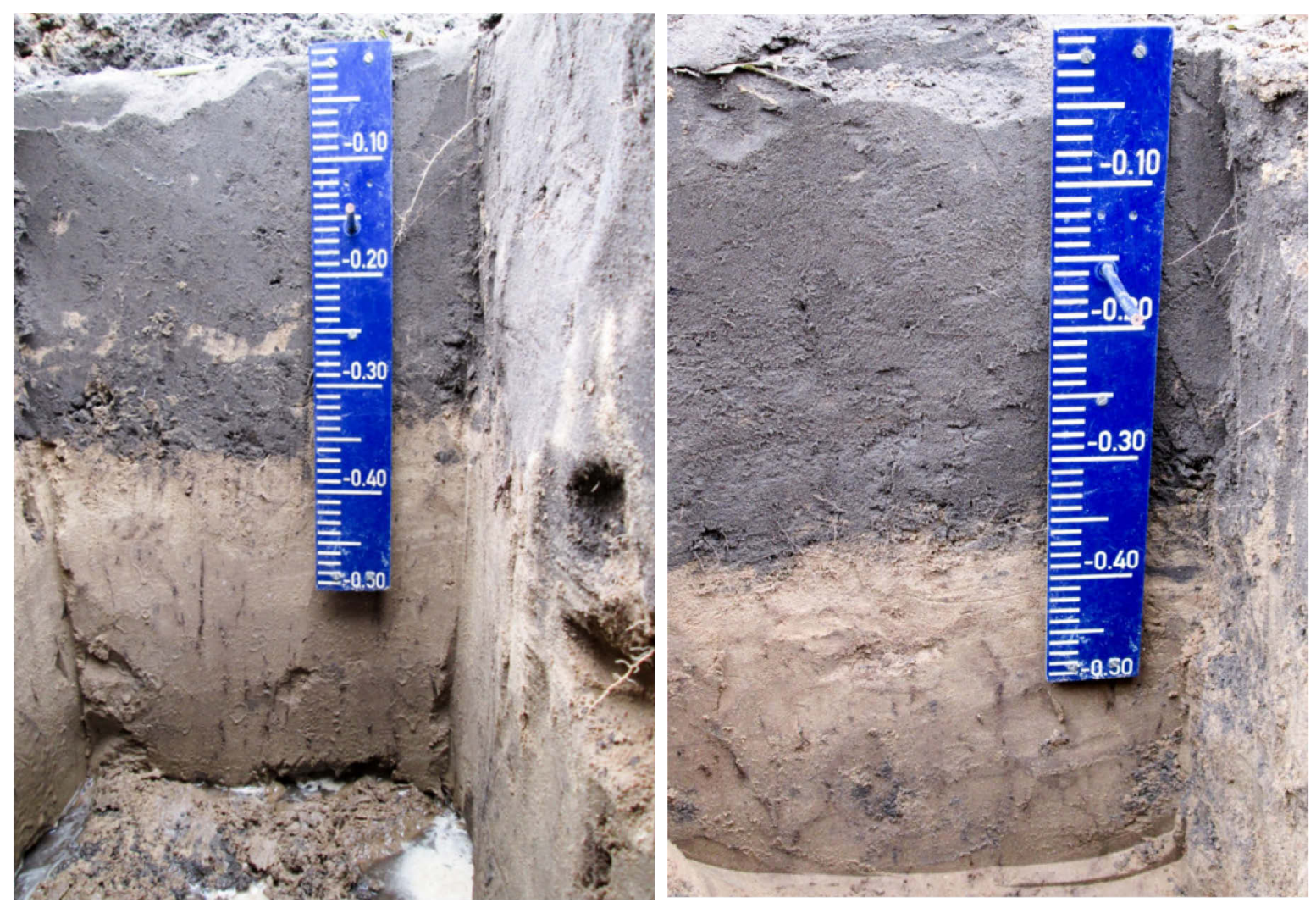

Figuur 2-2 Foto's van het bodemprofiel op de proeflocatie.

Tabel 2-4 Gemeten textuurverdeling en organische stofgehalte in drie bodemlagen (gemiddelde van duplomonsters).

\begin{tabular}{|c|c|c|c|c|c|c|c|c|c|c|}
\hline \multirow[t]{2}{*}{ Laag } & \multicolumn{9}{|c|}{ Textuur voor ranges in $\mu \mathrm{m}\left(\%, \mathrm{~g} \mathrm{~g}^{-1}\right)$} & \multirow{2}{*}{$\begin{array}{l}\text { OS } \\
\left(\%, g^{-1}\right)\end{array}$} \\
\hline & $0-2$ & $2-16$ & $16-50$ & $50-63$ & 63-105 & $105-150$ & $150-210$ & $210-420$ & $420-2000$ & \\
\hline $40-50$ & 1,1 & 0,2 & 0,0 & 0,4 & 4,2 & 23,7 & 45,0 & 23,9 & 0,8 & 0,6 \\
\hline $80-90$ & 0,9 & 0,1 & 0,6 & 0,7 & 5,7 & 24,9 & 41,5 & 24,0 & 1,1 & 0,5 \\
\hline
\end{tabular}




\subsubsection{Weersgegevens}

Het proefveld ligt circa 2,5 km ten OZO van vliegveld Volkel waar een KNMI-weerstation is gesitueerd. De dagelijkse neerslag en de Makkink-referentieverdamping voor de periode 2017-2020 zijn gebruikt om inzicht te krijgen in het neerslagtekort tijdens de groeiseizoenen en om de patronen in gemeten drukhoogte en grondwaterstand te kunnen verklaren.

\subsubsection{Drukhoogte en grondwaterstand}

Om een indruk te krijgen in welke mate de bodem uitdroogt, zijn tensiometers in enkelvoud geplaatst in de plots 6 (mais), 7 (sorghum C7) en 2 (sorghum Suzy; alleen in 2020). Per plot zijn twee tot vier tensiometers geïnstalleerd op de diepten (cm -mv): 25 (vanaf 2018), 50 (vanaf 2018), 85 en 105. Met tensiometers wordt de drukhoogte (vochtspanning) gemeten van het bodemvocht in de bodem $(<0$ indien bodem onverzadigd; $>0$ indien bodem verzadigd). Water beweegt in de bodem onder invloed van gradiënten in drukhoogte. Hoe droger de bodem, des te negatiever is de drukhoogte en des te meer de plant energie moet aanwenden om water aan de bodem te onttrekken. Tussen plots 6 en 7 is elk groeiseizoen een grondwaterstandpeilbuis geïnstalleerd, in 2018 en 2020 voorzien van een automatische drukopnemer. Zowel de drukhoogte als de grondwaterstand (alleen in 2018 en 2020) werd semi-continu (elke $6 \mathrm{u}$ ) geregistreerd in een datalogger en later grafisch weergegeven. In de jaren 2017 en 2019 is het continue verloop van de grondwaterstand afgeleid uit de tensiometerregistraties op diepte $105 \mathrm{~cm}$ en getoetst aan handgemeten grondwaterstanden.

\subsubsection{Indringingsweerstand}

Met een penetrologger kan de indringingsweerstand van de bodem worden gemeten. Een conus $\left(1 \mathrm{~cm}^{2}\right.$; tophoek $60^{\circ}$ ) wordt met constante kracht de bodem ingeduwd en de kracht (N) die daarvoor nodig is, wordt per cm diepte geregistreerd. Kracht per oppervlak is druk (MPa). Bij indringingsweerstanden groter dan 2 tot $3 \mathrm{MPa}$ kunnen de meeste wortels niet dieper wortelen. Penetrologger-waarnemingen zijn uitgevoerd op 11-10-2017 (gemiddelde van 6 penetraties per plot), 31-7-2019 (gemiddelde van 6 penetraties per plot), 10-10-2019 (gemiddelde van 10 penetraties per plot) en 5-10-2020 (gemiddelde van 7 penetraties per plot) in de laag 0-50 cm.

\subsubsection{Droge bulkdichtheid}

Naast de initieel gemeten droge bulkdichtheid (zie hierboven) zijn deze ook gemeten in 2018 (22-05-2018) en in 2020 (24-09-2020).

\subsubsection{Gravimetrisch watergehalte}

In de grondmonsters waarin $\mathrm{N}$-mineraal is gemeten, zijn ook gravimetrische watergehaltes ( $\mathrm{g}$ water per gram droge grond) gemeten. Zie paragraaf 2.4 voor beschrijving monstername.

\subsection{Gewasmetingen}

\subsubsection{Overzicht}

De gewasmetingen waren geconcentreerd in de eerste en laatste proefjaren. In de twee tussenjaren werd enkel gemeten in de behandelingen met mais (M1) versus sorghum C7 (S2) (Tabel 2-5). 
Tabel 2-5 Overzicht van de uitgevoerde gewasmetingen per proefjaar. De codes verwijzen naar de behandelingen.

\begin{tabular}{|c|c|c|c|c|}
\hline Gewasparameter & 2017 & 2018 & 2019 & 2020 \\
\hline Leaf Area Index, gewashoogte $\$$ & $\mathrm{M} 1^{\#}, \mathrm{~S} 2^{\#}$ & $\mathrm{M} 1, \mathrm{~S} 2$ & $\mathrm{M} 1, \mathrm{~S} 2$ & $\mathrm{M} 1,(\mathrm{~S} 1), \mathrm{S} 2, \mathrm{~S} 3$ \\
\hline Gewasopbrengst bovengronds & $\mathrm{M} 1, \mathrm{~S} 1, \mathrm{~S} 2, \mathrm{~S} 3$ & $\mathrm{M} 1, \mathrm{~S} 2$ & $\mathrm{M} 1, \mathrm{~S} 2$ & $\mathrm{M} 1, \mathrm{~S} 1, \mathrm{~S} 2, \mathrm{~S} 3$ \\
\hline Opbrengst groenbemester & & & & $\mathrm{M} 1, \mathrm{~S} 1, \mathrm{~S} 2, \mathrm{~S} 3$ \\
\hline Wortelmassa & $\mathrm{M} 1, \mathrm{~S} 1, \mathrm{~S} 2, \mathrm{~S} 3$ & & $\mathrm{M} 1, \mathrm{~S} 2$ & $\mathrm{M} 1, \mathrm{~S} 1, \mathrm{~S} 2, \mathrm{~S} 3$ \\
\hline Bodemstructuur & $\mathrm{M} 1, \mathrm{~S} 1, \mathrm{~S} 2, \mathrm{~S} 3$ & & & \\
\hline
\end{tabular}

\subsubsection{Bovengrondse metingen}

De gewasopbrengst en -voederwaarde werden aan het eind van het seizoen bepaald. Per plot werd $3 \times 3 \mathrm{~m}$ rij geoogst. Hiervan werd het aantal stengels geteld en vers gewicht bepaald. Van iedere $3 \times 3 \mathrm{~m}$ werden willekeurig negen planten genomen, waarvan na het hakselen een mengmonster werd genomen. Dit monster werd bij Eurofins (Wageningen) geanalyseerd op droge stof (DS) gehalte, $\mathrm{N}$-totaal, verteringscoëfficiënt van de organische stof (VCOS, methode Tilley \& Terry) en zetmeel (methode enzymatisch) en suiker.

Op 6 mei 2020 werd de bovengrondse biomassa bepaald van de groenbemester (wintergerst), gezaaid in oktober 2019. Per plot werd met een maaibalk een baan van 0,8 $55 \mathrm{~m}$ gemaaid, het materiaal gewogen en een submonster genomen voor bepaling van het DS-gehalte. Doel hiervan was een eerste indicatie te krijgen van een mogelijk voorvruchteffect (sorghum of mais) op de groei van de groenbemester.

Om de gewasontwikkeling tijdens het groeiseizoen te volgen, zijn gewashoogte en bladoppervlakteindex (Leaf Area Index, LAI; $\mathrm{m}^{2} \mathrm{~m}^{-2}$ ) gemeten in de groeiseizoenen 2018-2020 (Tabel 2-5). Anders dan bij overige gewasmetingen zijn LAI en gewashoogte slechts in één herhaling gemeten: namelijk in plots 6 (M1), 7(S2) en 2 (S3; alleen in 2020). Tijdens het laatste meetmoment in 2020 zijn wel alle zestien plots gemeten. Per plot werd de gewashoogte gemeten als het gemiddelde van de lengtes van twintig planten, en de LAI is het gemiddelde van vijftig registraties in elke behandeling. Het aantal meettijdstippen varieerde per jaar: drie in 2017 (5, 28 juli, 16 augustus; alleen LAI), vijf in 2018 (19 juli, 1, 14 en 28 augustus, 25 september), drie in 2019 (13 augustus, 4 september, 2 oktober) en acht in 2020 (20 mei, 22 juni, 6, 13 en 22 juli, 3 en 17 augustus, 23 september).

In 2020 zijn aan het eind van het groeiseizoen ook de gewashoogten en LAI gemeten van alle plots om een indruk te krijgen van de spreiding binnen behandelingen.

\subsubsection{Beworteling}

De beworteling van mais en sorghum werd beoordeeld door wortelmassa- en wortellengtemetingen.

Wortelmassa werd rond de oogsttijd gemeten in wortelmonsters per bodemlaag van $10 \mathrm{~cm}$, in 2017 en 2019 tot $50 \mathrm{~cm}$ diep en in 2020 tot $40 \mathrm{~cm}$ diep. Per plot en per diepte werden van drie plekken monsters verzameld met een wortelboor. In 2017 en 2019 werd dit zowel in de gewasrij als midden tussen de rijen (op $25 \mathrm{~cm}$ van de rijen) apart gedaan om een indruk te krijgen van zowel de verticale als de horizontale wortelverdeling. Door de afwijkende rijafstand van Piper (in 2017: $25 \mathrm{~cm}$ ) was de bemonstering 'tussen de rij' bij dat ras op 12,5 cm van de rijen. In 2020 werden monsters genomen op $1 / 4$ van de afstand tussen de rij, dus op $12,5 \mathrm{~cm}$ van de rij. De monsters werden grondig gespoeld op een zeef van 1,8 mm om alle minerale bodemdeeltjes te verwijderen. Hierna werd overgebleven niet-wortelmateriaal (bovengrondse plantenresten, stoppels van eerdere jaren, zaad etc.) zorgvuldig handmatig verwijderd om enkel wortelmateriaal over te houden. Dit wortelmateriaal werd gedroogd, 
eerst 24 uur op $70^{\circ} \mathrm{C}$, vervolgens 2 uur op $105^{\circ} \mathrm{C}$ en dan gewogen. Gewichten werden omgerekend naar kg DS per ha, rekening houdend met het aantal monsters en de diameter van de wortelboor (80 mm in 2017 en 2019 en 25 mm in 2020). Omdat de wortelmassa-bepaling door technische beperkingen in 2020 niet in de laag 40-50 cm gemeten kon worden, is de aanwezigheid van wortels onder de $40 \mathrm{~cm}$ visueel bepaald. Enkel in twee plots (S1 en S2) werden wortels aangetroffen, namelijk op $40 \mathrm{~cm}$. Wortellengte werd in 2020 gemeten in de bovenbeschreven wortelmassa-monsters voordat ze gedroogd werden. Wortellengte per diameterklassen werd per monster bepaald met de software WinRHIZO. Hiermee werden per bodemlaag berekend het aandeel wortellengte per diameterklassen $(0-0,5 \mathrm{~mm}, 0,5-2,0 \mathrm{~mm}$ en $>2,0 \mathrm{~mm}$ ) en de wortellengtedichtheid (WLD; wortellengte per bodemvolume: $\mathrm{cm} \mathrm{cm}^{-3}$ ).

In aanvulling op de wortelmetingen is in 2020 een afbraakproef uitgevoerd met wortel- en stoppelmateriaal en met de tea bag index (TBI) methode. Het materiaal, de methoden en de resultaten staan beschreven in Bijlage 2.

\subsubsection{Visuele bodemstructuurbeoordeling}

In 2017 werd na de oogst een visuele bodemstructuurbeoordeling uitgevoerd in één kuil per plot, in alle plots. De beoordeling vond plaats in de laag 0-25 cm en $25-45 \mathrm{~cm}$. Hierbij werd een schatting gemaakt van het aandeel kruimels, afgeronde en scherpe bodemstructuren (totaal 100\%). Daarnaast werd per kuil gemeten hoe diep de diepst zichtbare wortel zich bevond en werd voor de bewortelingsintensiteit een score gegeven (0: geen wortels; 10: zeer hoge wortelintensiteit).

\section{$2.4 \quad$ Nitraat}

In de jaren 2017 (23 mei, 18 oktober), 2018 (19 maart, 11 oktober) en 2019 ( 8 april, 11 oktober) is zowel voor als na het groeiseizoen $\mathrm{N}$-mineraal in de bodem $(0-90 \mathrm{~cm})$ gemeten in alle plots. In het voorjaar van 2017 is dat abusievelijk te laat gebeurd, na het toedienen van de bemesting, waardoor deze resultaten niet bruikbaar zijn. In het voorjaar van 2020 (24 maart) is alleen een $\mathrm{N}$-mineraal monster genomen van het proefveld als geheel, omdat in voorgaande jaren was gebleken dat de waarde nauwelijks boven de detectiegrens van $2 \mathrm{~kg} \mathrm{~N}$ ha-1 per bodemlaag van $30 \mathrm{~cm}$ kwam, en er bovendien weinig variatie optrad tussen de veldjes. De bemonstering in najaar 2020 werd uitgevoerd op 7 oktober. De grondbemonstering werd met een mechanische gutsboor achter op een tractor uitgevoerd. Hiervoor reed de tractor over de plots waarbij 7 tot 12 steken per plot werden genomen voor één mengmonster per laag van respectievelijk 0-30 cm, 30-60 cm en 60-90 cm beneden maaiveld. De boorgaten werden daarna opgevuld met een mengsel van zand met cement om kortsluiting tussen de bodemlagen te voorkomen. In het voorjaar van 2020 zijn monsters gestoken uit de scheidingsstroken tussen de plots, waardoor het opvullen van de boorgaten niet nodig was.

De grondmonsters werden in plastic zakken gekoeld bewaard en gestuurd naar Eurofins in Wageningen voor de bepaling van het gehalte aan minerale $\mathrm{N}$. Eurofins betrekt dit gehalte op het monstervolume en rekent vervolgens om naar $\mathrm{kg} \mathrm{ha}^{-1}$, waardoor de dichtheid geen rol speelt.

\subsection{Statistische analyse}

Voor parameters waarvan in herhalingen is gemeten zijn ANOVA's uitgevoerd om de significantie van behandelingseffecten te bepalen. Wanneer alle vier behandelingen gemeten zijn (jaren 2017 en 2020), is bij de ANOVA rekening gehouden met het 'Latin Square'-proefdesign met een blokeffect in zowel noord-zuid als oost-west richting (Figuur 2-1). In het geval van een statistisch significant effect $(P \leq 0,05)$ is vervolgens een 'least significant difference'-test uitgevoerd om aan te geven welke behandelingen significant van elkaar verschilden. Wanneer twee behandelingen gemeten zijn (voornamelijk 2018 en 2019), zijn de ANOVA's uitgevoerd met een blokeffect in één richting (noordzuid). De statistische analyse is uitgevoerd met R (versie 4.0.3) en package Agricolae (versie 1.3-3), of met Genstat (2018). 


\section{Resultaten en discussie}

\section{$3.1 \quad$ Meteorologie}

Figuur 3-1 geeft de cumulatieve neerslag en cumulatieve Makkink-referentieverdamping van KNMI meteostation Volkel weer; de cumulatieven zijn steeds op 1 april op nul gezet, omdat dit het begin van het hydrologische jaar aangeeft. Tabel 3-1 geeft de totale neerslag, totale Makkinkreferentieverdamping en het berekende neerslagtekort (neerslag - Makkink-referentieverdamping) voor de vier gewasgroeiperioden. In alle jaren was sprake van een neerslagtekort tijdens het groeiseizoen. Dit kan deels zijn aangevuld via capillaire opstijging uit het grondwater. Duidelijk is dat er in de jaren 2018 en 2019 sprake was van een groot neerslagtekort, hetgeen heeft kunnen leiden tot verminderde groei.

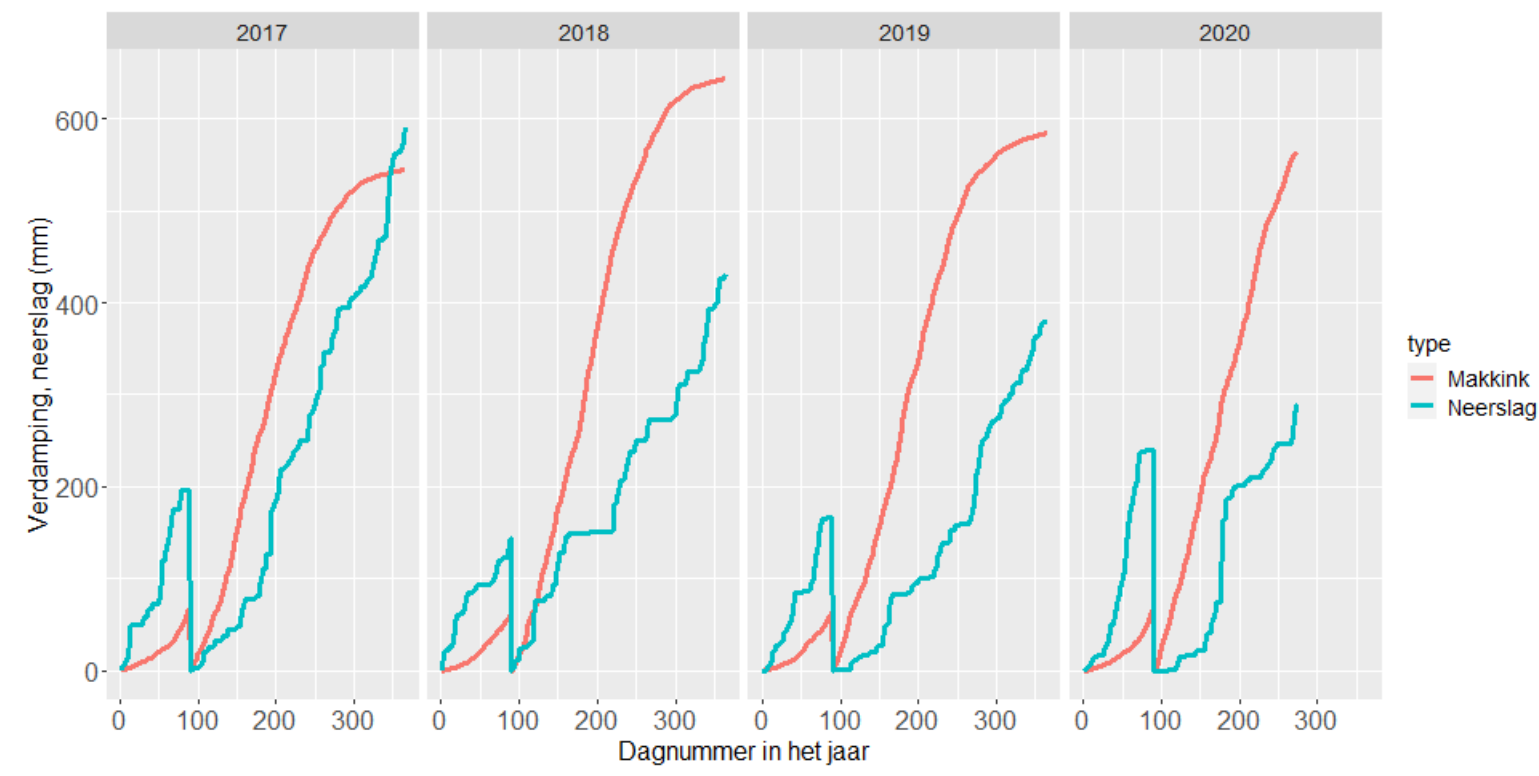

Figuur 3-1 Cumulatieve Makkink-referentieverdamping en cumulatieve neerslag voor de jaren 2017-2020 voor Odiliapeel (KNMI weerstation Volkel). Cumulatieven zijn gereset op 1 april (start hydrologisch jaar).

Tabel 3-1 Cumulatieve neerslag, Makkink-referentie verdamping en neerslagtekort (alles in $\mathrm{mm}$ ) gedurende de vier groeiseizoenen.

\begin{tabular}{|c|c|c|c|c|}
\hline Jaar & Groeiseizoen & Neerslag ( $\mathrm{mm})$ & $\begin{array}{l}\text { Makkink-referentie- } \\
\text { verdamping (mm) }\end{array}$ & Neerslagoverschot $(\mathrm{mm})$ \\
\hline 2017 & 23 mei - 28 september & 307 & 372 & -66 \\
\hline 2019 & 17 mei -7 oktober & 223 & 426 & -203 \\
\hline 2020 & 18 mei - 5 oktober & 291 & 425 & -134 \\
\hline
\end{tabular}




\subsection{Bodem}

\subsubsection{Waterretentie en doorlatendheid bij verzadiging}

De waterretentie meetpunten zijn weergegeven in Tabel 3-2. Tevens zijn hierbij vermeld de droge bulkdichtheid, het organische stofgehalte en de berekende porositeit en berekende luchtgehaltes bij twee drukhoogtes en de doorlatendheid bij verzadiging. De gemeten waterretentiemeetpunten zijn gebruikt om volledige curven volgens het Van Genuchten-model (1980) te fitten en deze zijn weergegeven in Figuur 3-2.

De dichtheid van de twee diepere lagen is groter dan $1,6 \mathrm{~g} \mathrm{~cm}^{-3}$ (porositeit $<0,4 \mathrm{~cm}^{3} \mathrm{~cm}^{-3}$ ) en kunnen voor zandgronden aangemerkt worden als verdichte lagen (Van den Akker, 2008; Van den Akker \& Hoogland, 2011). Luchtgehaltes bij $h=-50 \mathrm{~cm}$ minder dan $0,1 \mathrm{~cm}^{3} \mathrm{~cm}^{-3}$ worden als problematisch gezien voor de zuurstofvoorziening van de wortels (Van den Akker, 2008). In de bovenlaag en ook in de onderste twee lagen lijkt dit geen probleem te zijn. De doorlatendheid bij verzadiging is groot genoeg $\left(K_{\text {sat }}>10 \mathrm{~cm} \mathrm{~d}^{-1}\right.$; Van den Akker, 2008) om geen problemen te verwachten met betrekking tot infiltratie, en ook voor de ondergrond is $K_{\text {sat }}>10 \mathrm{~cm} \mathrm{~d}^{-1}$.

Tabel 3-2 Duplometingen op drie diepten van waterretentie bij vijf drukhoogtes (volumetrisch watergehalte in $\mathrm{cm} 3 \mathrm{~cm}-3$ ), de gemeten droge bulkdichtheid ( $\rho$ d) en organische stofgehalte (OS), de berekende porositeit (PV) en luchtgehaltes bij twee drukhoogtes en de gemeten doorlatendheid bij verzadiging (Ksat).

\begin{tabular}{|c|c|c|c|c|c|c|c|c|c|c|c|}
\hline \multirow[b]{2}{*}{ Laag $^{1}$} & \multicolumn{5}{|c|}{$\begin{array}{l}\text { Watergehaltes }\left(\mathrm{cm}^{3} \mathrm{~cm}^{-3}\right) \\
\text { bij } 5 \text { drukhoogtes }(\mathrm{cm})\end{array}$} & \multirow[t]{2}{*}{$\begin{array}{l}\text { pd } \\
\left(\mathrm{g} \mathrm{cm}^{-3}\right)\end{array}$} & \multirow[t]{2}{*}{$\begin{array}{l}\text { Os } \\
\left(\mathrm{g} \mathrm{g}^{-1}\right)\end{array}$} & \multirow[t]{2}{*}{$\begin{array}{l}\text { PV } \\
\left(\mathrm{cm}^{3} \mathrm{~cm}^{-3}\right)\end{array}$} & \multicolumn{2}{|c|}{$\begin{array}{l}\text { Luchtgehalte } \\
\left(\mathrm{cm}^{3} \mathrm{~cm}^{-3}\right)\end{array}$} & \multirow[t]{2}{*}{$\begin{array}{l}K_{\text {sat }} \\
\left(\mathrm{cm} \mathrm{d}^{-1}\right)\end{array}$} \\
\hline & -3 & -10 & -30 & -70 & -100 & & & & -50 & -100 & \\
\hline $15-20 / 25$ & 0,422 & 0,416 & 0,357 & 0,195 & 0,160 & 1,486 & 0,0247 & 0,430 & 0,154 & 0,270 & 121,1 \\
\hline $40-45 / 50$ & 0,297 & 0,292 & 0,282 & 0,118 & 0,076 & 1,689 & 0,0042 & 0,363 & 0,163 & 0,287 & 49,7 \\
\hline \multirow[t]{2}{*}{$80-85 / 90$} & 0,348 & 0,343 & 0,335 & 0,189 & 0,109 & 1,679 & 0,0046 & 0,367 & 0,104 & 0,257 & 93,4 \\
\hline & 0,348 & 0,341 & 0,330 & 0,166 & 0,091 & 1,693 & 0,0034 & 0,362 & 0,114 & 0,270 & 86,7 \\
\hline
\end{tabular}

1: de retentiemonsters waren $5 \mathrm{~cm}$ hoog en de $K_{\text {sat }}$ monsters waren $10 \mathrm{~cm}$ hoog

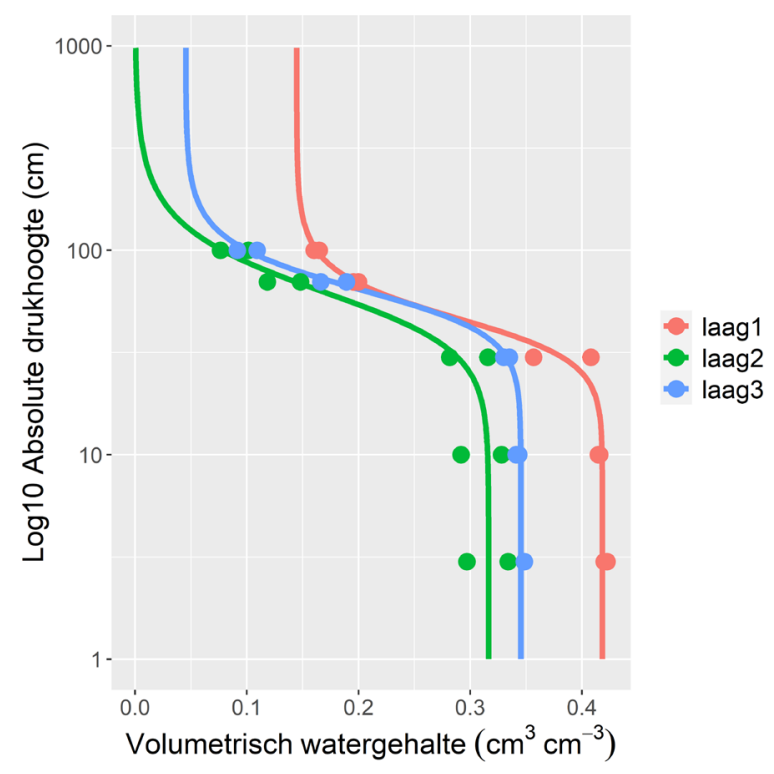

\begin{tabular}{|l|l|l|l|l|}
\hline Laag & $\begin{array}{l}\theta_{\mathrm{r}} \\
\left(\mathrm{cm}^{3} \mathrm{~cm}^{-3}\right)\end{array}$ & $\begin{array}{l}\theta_{\mathrm{s}} \\
\left(\mathrm{cm}^{3} \mathrm{~cm}^{-3}\right)\end{array}$ & $\begin{array}{l}\alpha \\
\left(\mathrm{cm}^{-1}\right)\end{array}$ & $\begin{array}{l}n \\
(-)\end{array}$ \\
\hline 1 & 0,14463 & 0,41840 & 0,02295 & 4,26058 \\
\hline 2 & 0,0 & 0,31649 & 0,01816 & 3,18451 \\
\hline 3 & 0,04542 & 0,34538 & 0,01682 & 4,10424 \\
\hline
\end{tabular}

Figuur 3-2 De waterretentiekarakteristieken voor de drie bodemlagen: symbolen zijn meetwaarden (Tabel 3-2) en de lijnen zijn de gefitte curven volgens Van Genuchten (1980), waarvoor de parameters in de tabel rechts van de figuur zijn vermeld. 


\subsubsection{Indringingsweerstand}

De indringingsweerstand (IW) werd gemeten in 2017, 2019 en 2020. De resultaten zijn weergegeven in Figuur 3-3. In 2019 werden significante verschillen gevonden op 28, 29 en $30 \mathrm{~cm}$ diepte en trends op 6, 32, 33 en $34 \mathrm{~cm}$ (Figuur 3-3). In de bodemlaag 20-30 cm was de gemiddelde IW hierdoor significant lager voor de behandeling met C7 dan voor de mais behandeling (Tabel 3-3).
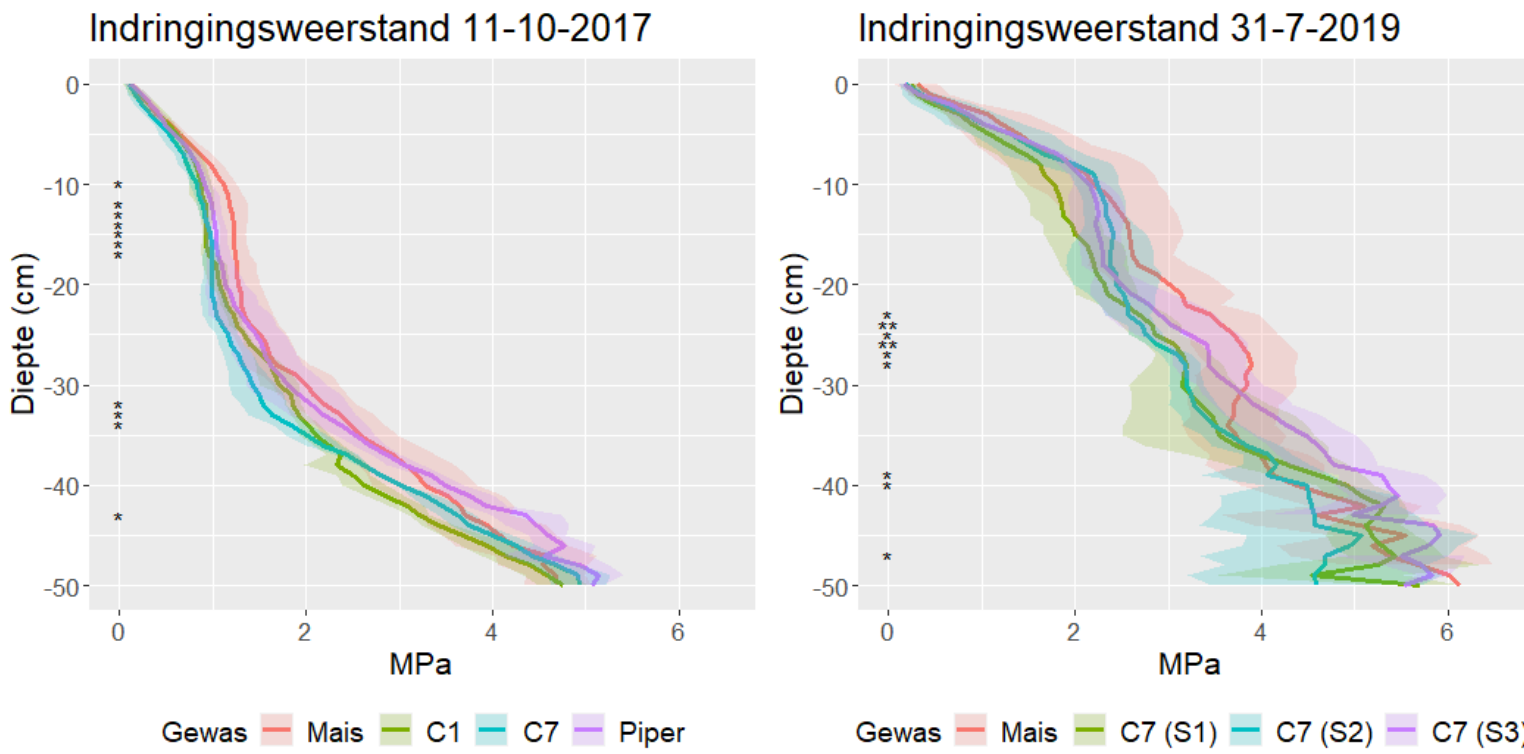

Indringingsweerstand 10-10-2019

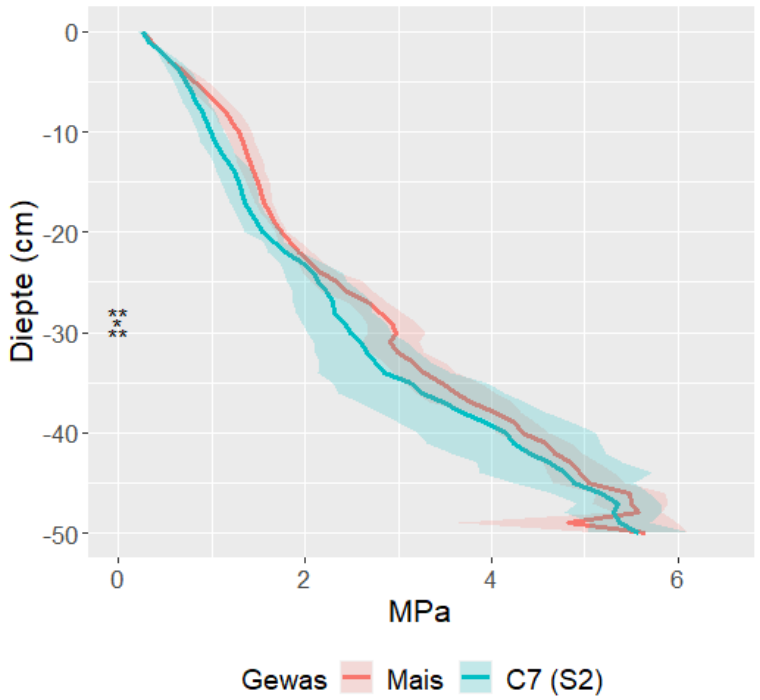

Indringingsweerstand 5-10-2020

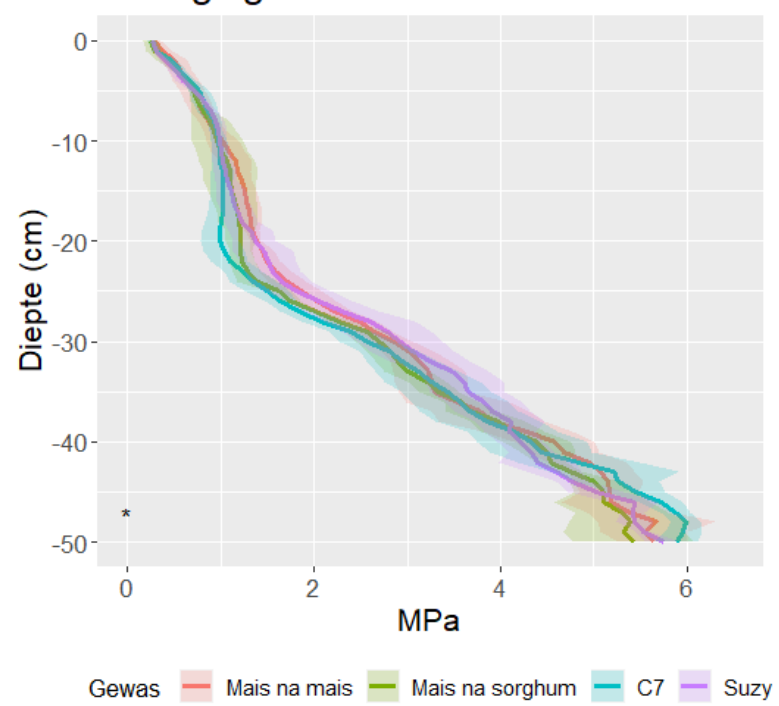

Figuur 3-3 Indringingsweerstand in 11-20-2017 (zes penetraties per plot), 31-7-2019 (zes penetraties per plot), 10-10-2019 (tien penetraties per plot) en 5-10-2020 (zeven penetraties per plot), gemeten met een conus van $1 \mathrm{~cm}^{2}$ en een tophoek van $60^{\circ}$. De significantie van de behandelingseffect is per centimeter aangegeven: $* *=P<0,01 *=P<0,05$, en geen aanduiding $=$ $P>0,05$. Het gekleurde gebied geeft + en - de standaard deviatie tussen de gemiddeldes per plot weer.

In 2020 werd slechts een significant behandelingseffect gemeten op $47 \mathrm{~cm}$ diepte en een trend op 21 en $22 \mathrm{~cm}$ (Figuur 3-3). Voor de vijf verschillende bodemlagen van $10 \mathrm{~cm}$ werden daarom geen behandelingseffecten waargenomen (Tabel 3-4).

Wortelgroei wordt bij een indringingsweerstand van $300 \mathrm{~N}\left(=3 \mathrm{MPa}\right.$ bij $\left.1 \mathrm{~cm}^{2}\right)$ sterk verminderd en kan een verdichtte laag niet meer losmaken. Die grenswaarde wordt steeds bereikt op circa $30-35 \mathrm{~cm}$ diepte (Figuur 3-3), wat overeenkomt met de bovenkant van de verdichte ondergrond. 
Tabel 3-3 Indringingsweerstand $(N)$ gemeten met een conus van $1 \mathrm{~cm}^{2}$ en een tophoek van $60^{\circ}$ op 10 oktober 2019, tot $50 \mathrm{~cm}$ en per bodemlaag van $10 \mathrm{~cm}$. Omrekenen naar MPa: delen door 100.

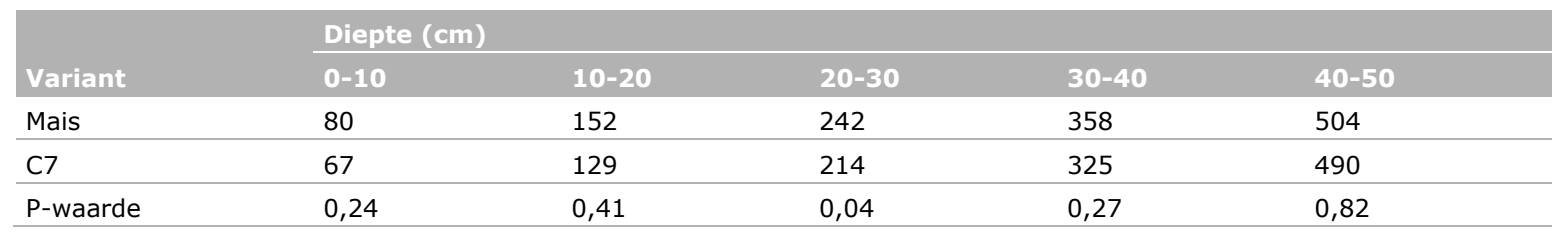

Tabel 3-4 Indringingsweerstand $(N)$ gemeten met een conus van $1 \mathrm{~cm}^{2}$ en een tophoek van $60^{\circ}$ op 5 oktober 2020, tot $50 \mathrm{~cm}$ en per bodemlaag van $10 \mathrm{~cm}$. Omrekenen naar MPa: delen door 100.

\begin{tabular}{|c|c|c|c|c|c|}
\hline Variant & \multicolumn{5}{|c|}{ Diepte $(\mathrm{cm})$} \\
\hline Mais na mais & 67 & 125 & 206 & 372 & 536 \\
\hline $\mathrm{C7}$ & 69 & 113 & 181 & 351 & 499 \\
\hline Suzy & 67 & 101 & 168 & 350 & 498 \\
\hline
\end{tabular}

De indringingsweerstand kan het best gemeten worden wanneer de bodem op ongeveer veldcapaciteit is: de drukhoogte is dan circa $-100 \mathrm{~cm}(\mathrm{pF}=2)$. Grofweg kan gesteld worden dat deze situatie aanwezig was ter hoogte van de verdichte laag tijdens de metingen in het najaar van 2017, 2019 en 2020. Hiervoor zijn de tensiometer-waarnemingen op diepten $30 \mathrm{~cm}$-mv (net boven start verdichte laag) en $50 \mathrm{~cm}$-mv (in de verdichte laag) weergegeven (afgeleid uit de data gepresenteerd in paragraaf 3.2.4). Voor 2019 en 2020 geldt dat de tensiometer-waarnemingen iets eerder zijn beëindigd dan het moment waarop de penetrologger-metingen zijn uitgevoerd. De waarneming eind juli 2019 was onder iets drogere omstandigheden uitgevoerd: drukhoogte variërend van gemiddeld circa -165 tot $-245 \mathrm{~cm}$.

Tabel 3-5 De drukhoogte $(\mathrm{cm})$ ter hoogte van de verdichte laag op de dagen waarop de penetrologger-waarnemingen zijn verricht; de waarden tussen haakjes geven de diepte van de tensiometer weer. Omdat in 2017 geen ondiepe tensiometers aanwezig waren, is hier alleen de waarde op $80 \mathrm{~cm}$ diepte gegeven. In 2019 en 2020 is de indringingsweerstand gemeten enkele dagen nadat de tensiometers uit het veld verwijderd waren; die datum staat vermeld tussen haakjes.

\begin{tabular}{llll} 
Datum & M1 (plot 6) & C7 (plot 7) & Suzy (plot 2 in 2020) \\
\hline $11-10-2017$ & $16(80)$ & $20(80)$ & n.v.t. \\
\hline $31-07-2019$ & $-220(30)$ & $-437(30)$ & n.v.t. \\
& $-109(50)$ & $-49(50)$ & n.v.t. \\
\hline $10-10-2019(02-10-2019)$ & $-73(30)$ & $-73(30)$ & \\
& $-51(50)$ & $-51(50)$ & n.d. $(30)^{\$}$ \\
\hline $05-10-2020(24-09-2020)$ & $-115(30)$ & $-119(30)$ & $-83(50)$ \\
\hline
\end{tabular}

n.d.: niet gemeten;

$\$$ : bovenste tensiometer in plot 2 functioneerde aan eind van de proef niet goed

\subsubsection{Droge bulkdichtheid}

In 2018 en 2020 zijn de droge bulkdichtheden gemeten ter plaatse van de verdichte laag in studieplots 2, 6 en 7 (Tabel 3-6). De laag 35-45 cm heeft een grotere dichtheid dan de laag 25-35 cm in beide jaren. Deze laag $25-35 \mathrm{~cm}$ is het onderste deel van de bouwvoor en is regelmatig losgemaakt en heeft een hoger organische stofgehalte dan de ondergrond, waardoor deze minder verdichtingsgevoelig is. De dichtheid gemeten in 2020 is wat geringer dan gemeten in 2018. Deels komt dit doordat de meting in 2020 is uitgevoerd door ringmonsters in het veld te steken en deze in een zak te legen. Bij het leeghalen van de zak in het laboratorium kon niet al het bodemmateriaal uit 
de zak verwijderd worden, waardoor de dichtheid iets is onderschat bij deze aanpak. Het is niet duidelijk of dit een groot effect op de berekende dichtheid heeft gehad. De dichtheden in 2018 vallen hoger uit dan gemeten in 2017 en 2020. Daarbij moet worden bedacht dat in 2017 de laag 40-45 cm is bemonsterd en in 2018 de laag $35-40 \mathrm{~cm}$. De laag $35-40 \mathrm{~cm}$ is meer aan verdichting door hoge wiellasten blootgesteld dan de laag $40-45 \mathrm{~cm}$ en zal daardoor dichter zijn.

Tabel 3-6 Droge bulkdichtheid als functie van de diepte ter hoogte van de verdichte bodemlaag gemeten in de jaren 2017 (alleen veldgemiddelde bij aanvang), 2018 (22-05-2018) en 2020 (24-09-2020) voor de studie plots 2 (S3; sorghum, Suzy; alleen 2020), 6 (M1; mais) en 7 (S2; sorghum, C7).

\begin{tabular}{lllllllll}
2017 & \multicolumn{9}{c}{2018} & \multicolumn{9}{c}{2020} & & S2 \\
Diepte & Gemiddeld & Diepte & M1 & S2 & Diepte & M1 & 1453,6 & 1424,9 \\
\hline $15-20$ & 1478,0 & $25-30$ & 1589,1 & 1609,75 & $20-25$ & 1456,2 & 1453 \\
\hline $40-45$ & 1677,5 & $35-40$ & 1638,8 & 1727,2 & $35-40$ & 1570,5 & 1639,1 & 1579,8 \\
\hline $80-85$ & 1686,0 & n.d. & n.d. & n.d. & $45-50$ & 1629,8 & 1640,7 & 1628,6 \\
\hline
\end{tabular}

n.d.: niet gemeten

\subsubsection{Drukhoogte en grondwaterstand}

\section{Vochtspanningen en grondwaterstanden 2017}

In Figuur 3-4 zijn de vochtspanningen (drukhoogten) op een diepte van $79 \mathrm{~cm}$ (snijmais) en op $80 \mathrm{~cm}$ (sorghum C7) gepresenteerd. In 2017 zijn geen tensiometers in de bouwvoor geplaatst, omdat die naar verwachting direct zouden doorslaan (buiten hun meetbereik zouden komen) doordat de bouwvoor al eind juni zeer droog was. De diepere tensiometers zijn gebruikt om de grondwaterstand te volgen. Uit Figuur 3-4 volgt dat op 12 juli 2017 na een regenbui van $44 \mathrm{~mm}$ het droge voorjaar in één keer is omgeslagen in een relatief natte zomer en najaar. Op 12 juli is in 2017 de laagste grondwaterstand bereikt waarna deze door de grote neerslag circa $25 \mathrm{~cm}$ omhoog schiet. Daarna volgt een periode met af en toe regen waarbij door de gewasverdamping toch een gering neerslagtekort optreedt. Eind augustus is bijna de grondwaterstand van 7 juli bereikt, maar daarna maakt een natte periode daar een eind aan en gaat het profiel vernatten. Het was de bedoeling om met de tensiometers op circa $80 \mathrm{~cm}$ diepte na te gaan of de sorghum het profiel door een betere beworteling uiteindelijk dieper zou uitdrogen dan de snijmais. Het blijkt echter dat er op $80 \mathrm{~cm}$ diepte nagenoeg geen verschil in vochtspanning optreedt tussen de sorghum en de snijmais. Bovendien blijkt het zand op die diepte bijna volledig verzadigd te blijven: de laagste vochtspanning is circa $-33 \mathrm{~cm} \mathrm{H}_{2} \mathrm{O}$.

Samengevat kan worden gesteld dat beide gewassen in 2017 geen last van droogte hebben ondervonden en diepere beworteling voor beide gewassen niet noodzakelijk was. 


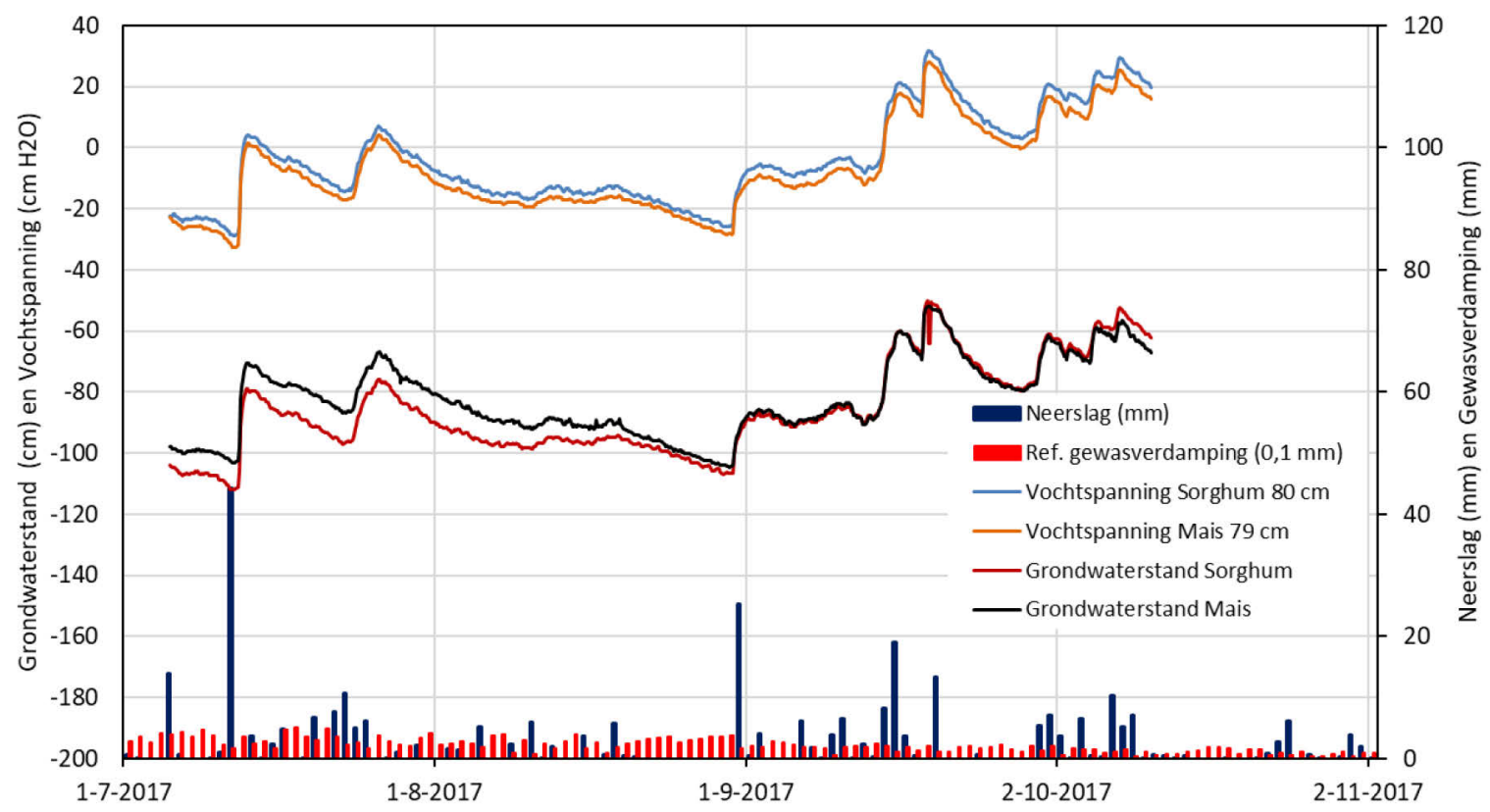

Figuur 3-4 Neerslag en verdamping en vochtspanning op $80 \mathrm{~cm}$ diepte en grondwaterstanden in 2017.

\section{Vochtspanningen en grondwaterstanden 2018}

Het jaar 2018 was zeer droog, dat ook al in het voorjaar uitzonderlijk droog was. Sorghum wordt laat in het voorjaar gezaaid (en daarom de mais ook), waardoor een droog voorjaar een slechte start is voor het gewas. Op 8 juni heeft het toch nog $17 \mathrm{~mm}$ geregend, wat op zich een geluk was. Echter daarna volgde een lange periode met geen of een enkele $\mathrm{mm}$ regen. Een en ander is aangegeven in Figuur 3-5. Voor dit project, dat gaat over het toepassen van sorghum als droogtetolerant diepwortelend gewas, lijkt 2018 op het eerste gezicht een goed jaar om de verschillen met snijmais te laten zien.

Met een grondwaterstandbuis tussen de plotjes met snijmais en sorghum zijn de grondwaterstanden vanaf begin juni gevolgd (Figuur 3-5). Uit Figuur 3-5 volgt dat de regenbui van 8 juni een snelle reactie in grondwaterstandverhoging geeft. Ditzelfde geldt voor de regenbui van 9 augustus, die met $27 \mathrm{~mm}$ regen het einde van een periode van twee maanden zonder neerslag aangeeft. Daarna stijgt de grondwaterstand geleidelijk, maar blijft nog ver onder de waarden die in 2017 in deze periode werden gemeten (zie Figuur 3-4). De snelle reacties van het grondwaterverloop op regenbuien in zowel 2017 als 2018 geven aan dat de zeer dichte ploegzool geen belemmering vormt voor de infiltratie van water naar de ondergrond. De tensiometers zijn na het begin van de opkomst van beide gewassen eind juni geïnstalleerd op diepten van 28, 80 en $105 \mathrm{~cm}$ diepte. De twee tensiometers in de bouwvoor op een diepte van $28 \mathrm{~cm}$ bleken al zeer snel uitgedroogd (zie Figuur 3-5) en sloegen binnen enkele dagen door. Hieruit blijkt dat de bouwvoor al in een vroeg stadium van de gewasgroei sterk was uitgedroogd.

De verwachting was dat de dichte ploegzool ondoordringbaar zou zijn voor de maiswortels, terwijl de sorghumwortels deze barrière wel aan zouden kunnen en wel diep in de ondergrond zouden dringen en daar water zouden onttrekken. Dit zou goed tot uitdrukking moeten komen in de vochtspanningen gemeten met de tensiometers op $80 \mathrm{~cm}$ diepte. Er blijkt echter geen verschil in vochtspanningen op te treden. Ook zijn de tensiometers bij zowel snijmais als sorghum op $80 \mathrm{~cm}$ diepte nagenoeg in hydrostatisch evenwicht met de grondwaterstand. Geconcludeerd wordt dat beide gewassen niet of slechts in beperkte mate van het water in de ondergrond kunnen profiteren door hun beperkte bewortelingsdiepte. 


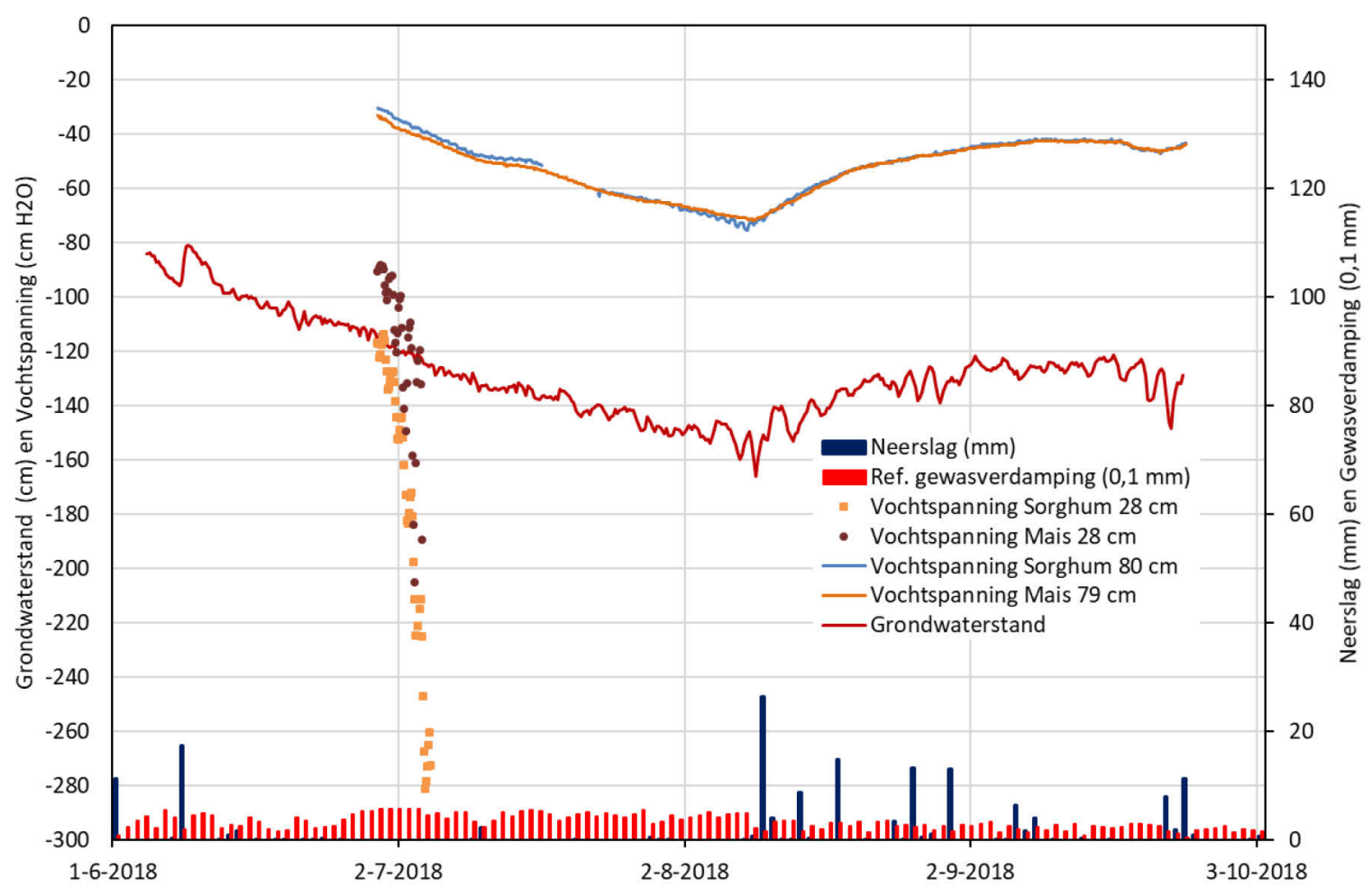

Figuur 3-5 Neerslag en verdamping en vochtspanning op $80 \mathrm{~cm}$ diepte en grondwaterstanden in 2018.

\section{Vochtspanningen en grondwaterstanden 2019}

In Figuur 3-6 zijn de vochtspanningen (drukhoogtes) in de bouwvoor gepresenteerd. Door een storing in de registratie beginnen de metingen pas op 31 juli. Het blijkt dat de sorghum $\mathrm{C} 7$ de bouwvoor op een diepte van $28 \mathrm{~cm}$ wat sterker uitdroogt dan de mais. De laagste vochtspanning bij de sorghum is $-473 \mathrm{~cm}$ waterdruk. Bij de snijmais is dat $-240 \mathrm{~cm}$ waterdruk. Na enkele regenbuien in de tweede week van augustus is de vochttoestand in de bouwvoor voor de sorghum C7 en de mais ongeveer gelijk. In Figuur 3-7 zijn de vochtspanningen op diepten van 50 en $80 \mathrm{~cm}$ gepresenteerd. Op een diepte van $80 \mathrm{~cm}$ zijn de vochtspanningen bij de sorghum C7 en de mais nagenoeg gelijk en in hydrostatisch evenwicht met de grondwaterstand. Deze grondwaterstand ligt vrij stabiel op circa $135 \mathrm{~cm}-\mathrm{mv}$ en loopt op naar eerst 120 tot $130 \mathrm{~cm}$-mv en stijgt na regenbuien eind september naar $100 \mathrm{~cm}$-mv. Op $50 \mathrm{~cm}$ diepte was alleen bij de mais een tensiometer geïnstalleerd. Op een diepte van $50 \mathrm{~cm}$ blijkt de droogte in de bouwvoor wel enige invloed te hebben, maar deze laag blijft relatief vochtig. De regenbuien in de tweede week van augustus worden blijkbaar volledig door de bouwvoor opgenomen, want de tensiometer op $50 \mathrm{~cm}$ diepte reageert nauwelijks en op dat moment is de bouwvoor relatief natter dan de laag op $50 \mathrm{~cm}$. Dit duurt tot begin september, waarna het profiel na een serie regenbuien eind september op 2 oktober ongeveer in hydrostatisch evenwicht is gekomen. 


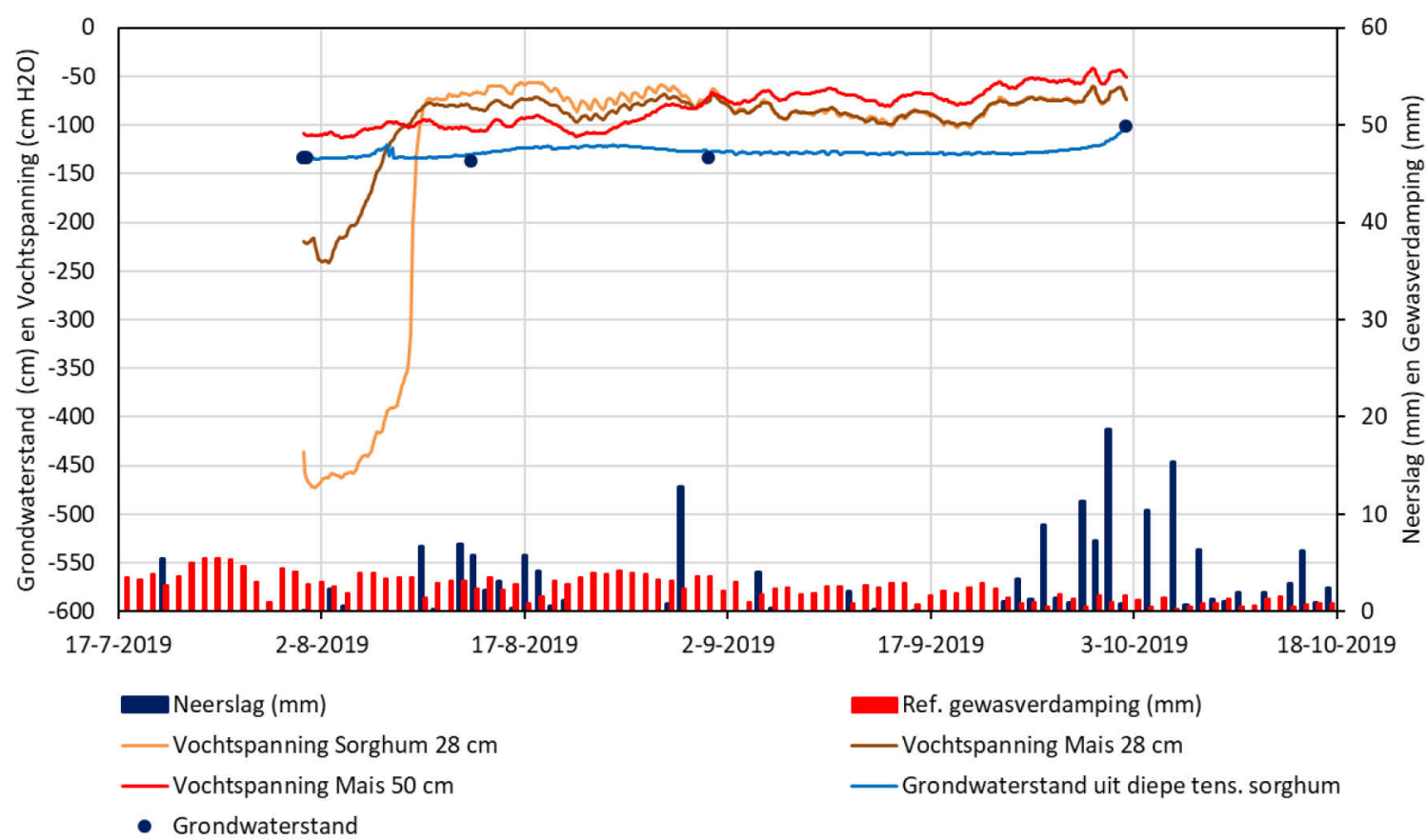

Figuur 3-6 Vochtspanningen op een diepte van $28 \mathrm{~cm}-m v$ en grondwaterstanden zoals gemeten bij sorghum C7 in plot 7 en de snijmais in plot 6 in 2019. De continue grondwaterstand is bepaald aan de hand van de metingen met de diepste tensiometer op $105 \mathrm{~cm}-\mathrm{mv}$ in het sorghumveldje. Deze komt goed overeen met de handmetingen van de grondwaterstand.

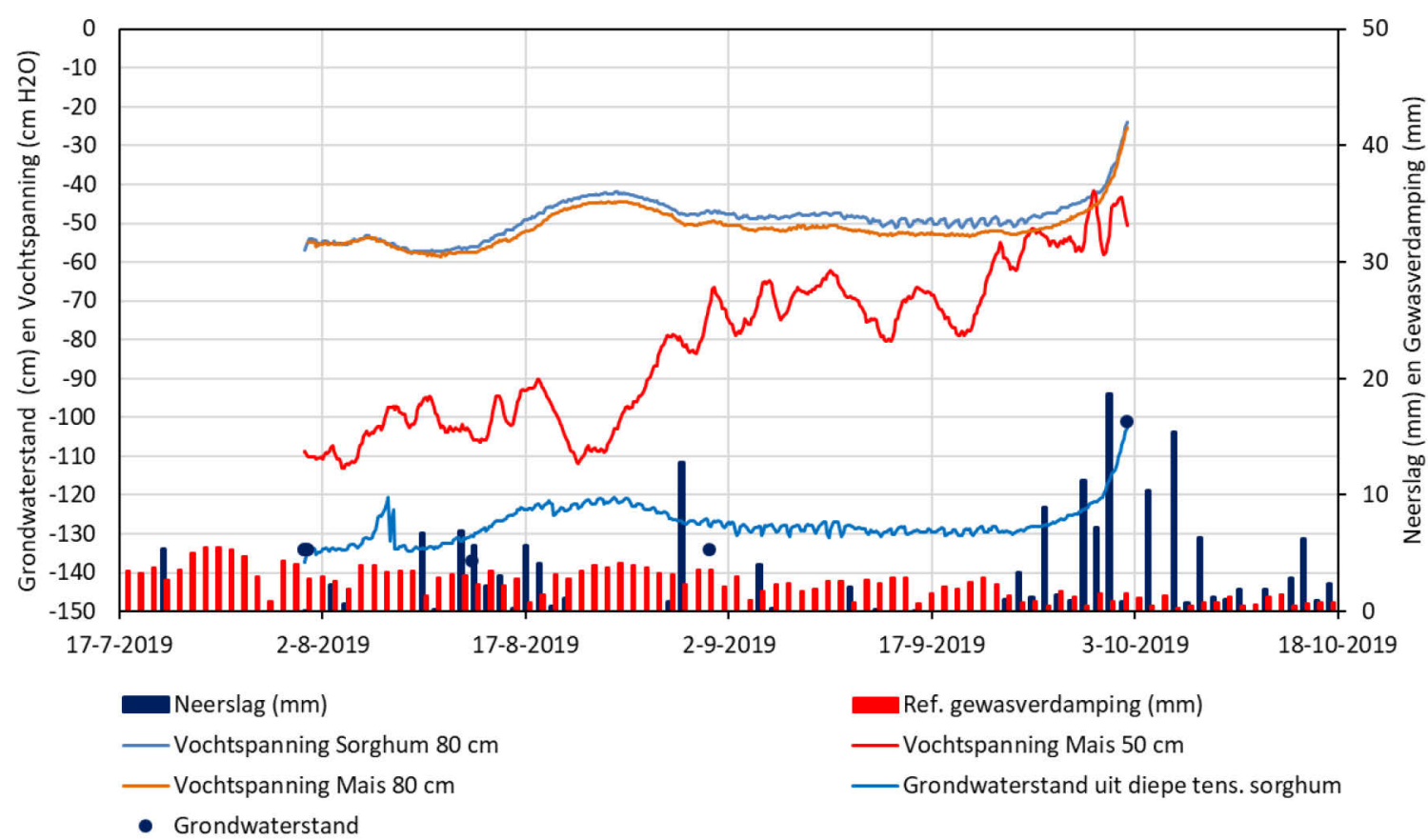

Figuur 3-7 Vochtspanningen op diepten van 50 en $80 \mathrm{~cm}$-mv en grondwaterstanden zoals gemeten bij sorghum C7 en snijmais in 2019. De continue grondwaterstand is bepaald aan de hand van de metingen met de diepste tensiometer op $105 \mathrm{~cm}-m v$ in het sorghumveldje. Deze komt goed overeen met de handmetingen van de grondwaterstand.

\section{Vochtspanningen en grondwaterstanden 2020}

In 2020 is op 3 plotjes de vochtspanning gemonitord op diepten van 25, 50, 80 en $105 \mathrm{~cm}$. Aan plot 7 (continu sorghum C7) en plot 6 (continu mais) was in eerdere jaren ook gemeten. De monitoring aan plot 2 (2017 sorghum Piper, 2018 en 2019 sorghum C7, 2020 sorghum Suzy) is alleen in 2020 
gebeurd. De tensiometers zijn aangebracht op 10 juni 2020 (Figuur 3-8). Op dat moment was de sorghum net zichtbaar opgekomen. De mais was toen al duidelijk verder in de groei (zie ook de foto's genomen op 10 juni 2020; Figuur 3-13). Door enkele regenbuien in de eerste week van juni was de grond redelijk vochtig. Een zware regenbui op 26 juni en een minder zware regenbui op 1 juli zijn duidelijk terug te vinden in de vochtspanningsmetingen en de grondwaterstandmetingen in Figuur 3-9 en Figuur 3-10. Uit Figuur 3-9 blijkt uit de tensiometers op een diepte van $25 \mathrm{~cm}$ dat de $35 \mathrm{~cm}$ dikke bouwvoor bij de sorghum C7 en de snijmais gedurende het gehele groeiseizoen voldoende water had. Dit geldt niet voor sorghum Suzy. Vanaf begin augustus begint de bouwvoor op $25 \mathrm{~cm}$ diepte sterk uit te drogen, waardoor op 26 augustus de tensiometer 'doorslaat', wat betekent dat het meetbereik van de tensiometer wordt overschreden doordat de onderdruk in de tensiometer zo laag is dat luchtintree plaatsvindt door het keramische materiaal van de tensiometer heen. Na 26 augustus zijn de gemeten waarden daarom niet meer betrouwbaar.

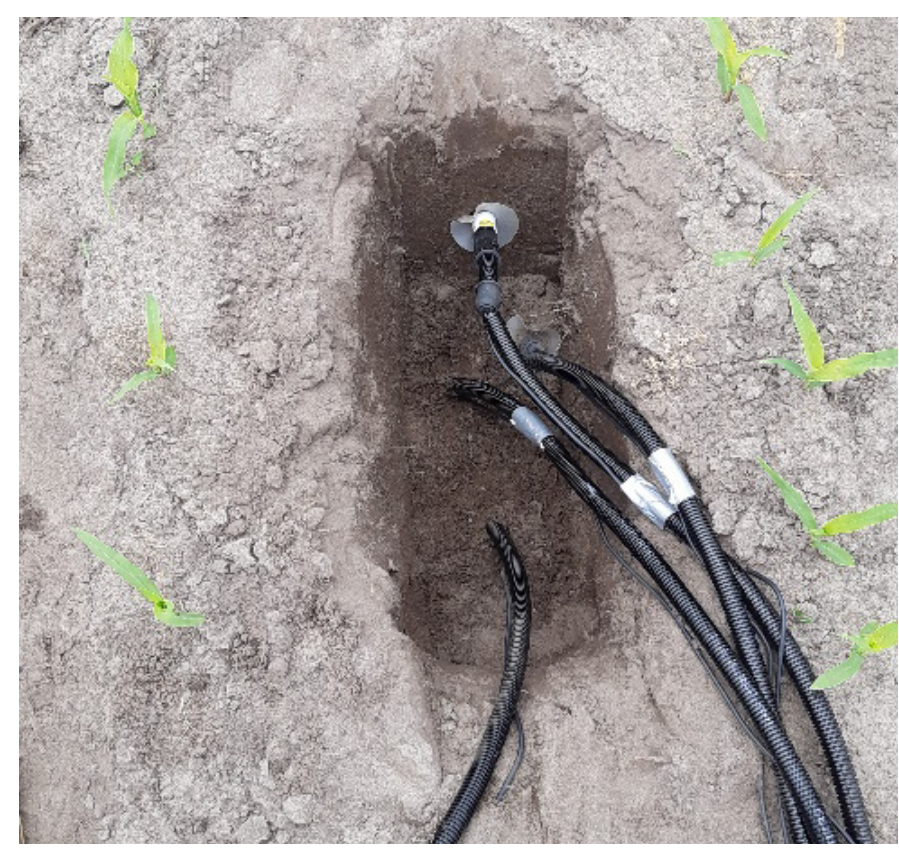

Figuur 3-8 Tensiometers direct na installatie (10-06-2020; foto: Jan van Kleef).

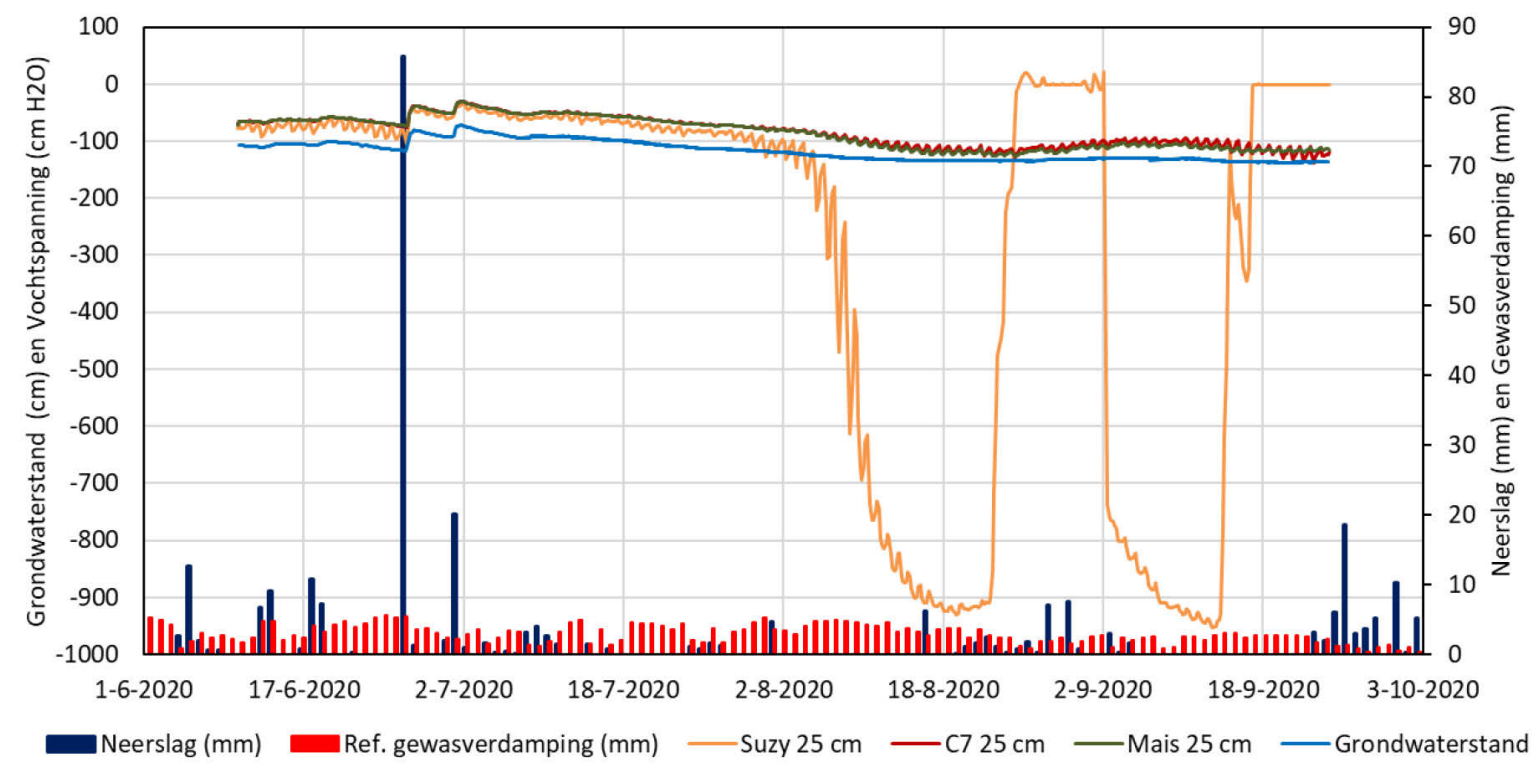

Figuur 3-9 Vochtspanningen op een diepte van $25 \mathrm{~cm}$-mv en grondwaterstanden zoals gemeten bij sorghum Suzy, sorghum C7 en de snijmais in 2020 en de grondwaterstand gemeten tussen de plotjes 6 (mais) en 7 (sorghum C7). 
In Figuur 3-10 zijn de vochtspanningen op een diepte van 50, 80 en $105 \mathrm{~cm}$ diepte gepresenteerd. De curven zijn te groeperen in deze drie diepten. De laagste vochtspanningen worden gemeten door de tensiometers op een diepte van $105 \mathrm{~cm}$ en dit zijn dan ook de bovenste drie curven in de figuur. De vochtspanningen zijn op alle diepten min of meer in hydrostatisch evenwicht met de grondwaterstand. Alleen de vochtspanning op een diepte van $50 \mathrm{~cm}$ is bij sorghum Suzy iets lager (de onderste curve bij het groepje van onderste drie curven). Geconstateerd kan worden dat de ondergrond in 2020 niet is uitgedroogd.

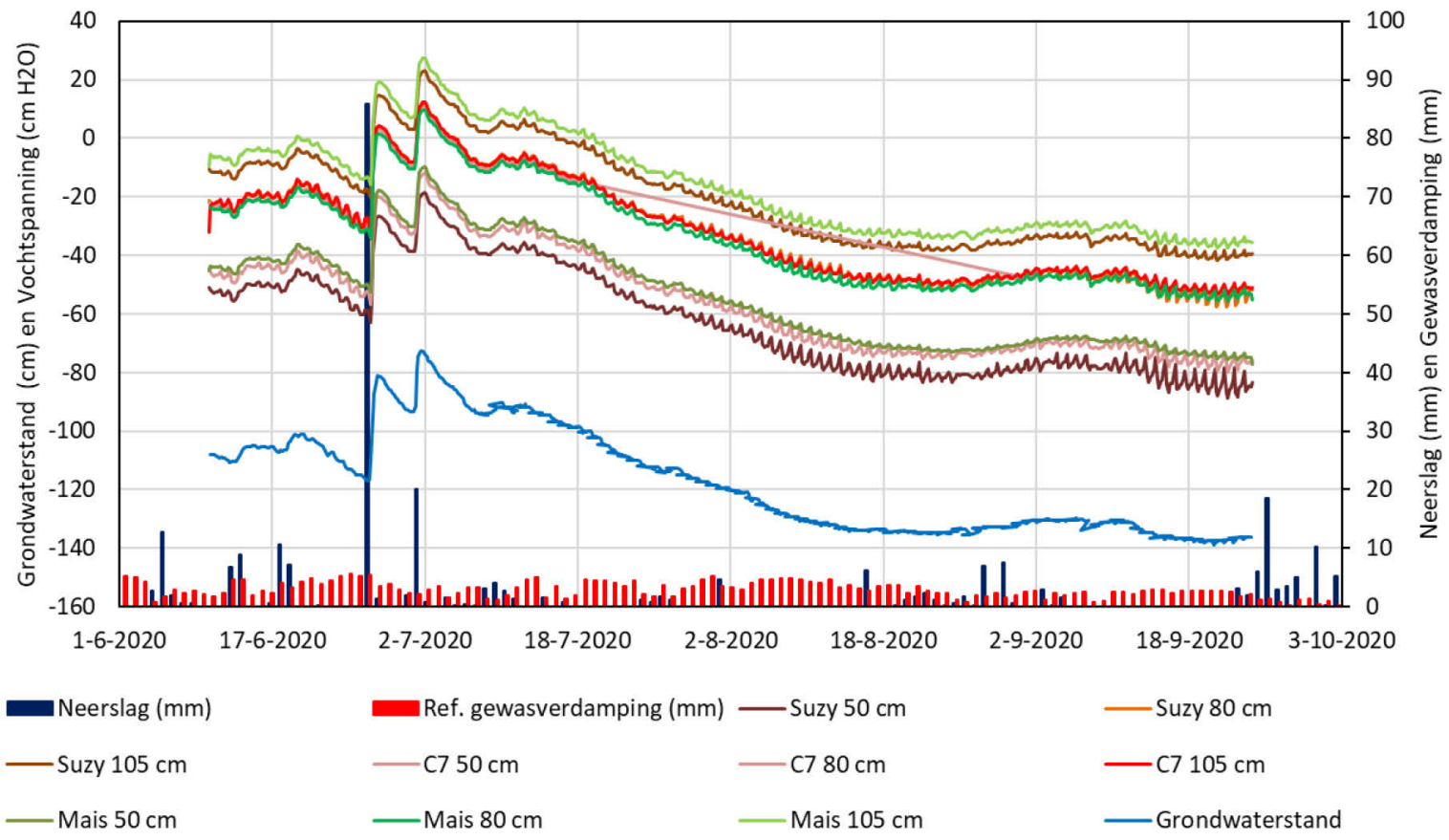

Figuur 3-10 Vochtspanningen op diepten van 50, 80 en $105 \mathrm{~cm}$-mv en grondwaterstanden zoals gemeten bij sorghum Suzy, sorghum C7 en de snijmais in 2020.

\section{Samenvatting 2017-2020}

De verwachting was dat de dichte ploegzool ondoordringbaar zou zijn voor maiswortels, terwijl sorghumwortels deze barrière wel zouden doordringen en wel diep in de ondergrond zouden groeien en daar water zouden onttrekken. Dit zou tot uitdrukking moeten komen in de vochtspanningen gemeten met de tensiometers tot op $80 \mathrm{~cm}$ diepte en misschien op $105 \mathrm{~cm}$ diepte. Er bleken echter geen verschillen in vochtspanningen op te treden. Ook waren de tensiometers op $80 \mathrm{~cm}$ diepte nagenoeg in hydrostatisch evenwicht met de grondwaterstand. In 2019 en 2020 zijn ook tensiometers geplaatst op een diepte van $50 \mathrm{~cm}$. Ook deze bleven nagenoeg in evenwicht met de grondwaterstand. Dit kan ook worden verklaard uit de relatief vrij hoge grondwaterstand, die vaak niet dieper kwam dan $130 \mathrm{~cm}-\mathrm{mv}$. Een zekere capillaire aanlevering van grondwater naar de bouwvoor is daardoor wel mogelijk. Geconcludeerd wordt dat zowel de sorghum als de mais niet of slechts in beperkte mate van het water in de ondergrond profiteerde door hun beperkte bewortelingsdiepte. Anderzijds blijkt de hoeveelheid water in de $35 \mathrm{~cm}$ dikke bouwvoor in 2019 en 2020 voor de snijmais en de sorghum C7 in principe voldoende om verdroging te voorkomen. Daarbij moet worden bedacht dat in 2017 geen vochtspanningen in de bouwvoor zijn gemeten. Dat er in 2019 en 2020 geen duidelijk watertekort leek op te treden, komt ook omdat door de late opkomst van de mais en met name van de sorghum (en de tegenvallende gewasopbrengsten) de waterbehoefte vrij beperkt bleef. Er is geen duidelijk verklaring voor de sterke uitdroging van de bouwvoor bij de sorghum Suzy in 2020, terwijl bij de snijmais en de sorghum C7 dit duidelijk niet het geval was. 


\subsubsection{Watergehalte voor- en najaar}

Ten tijde van de $\mathrm{N}$-mineraal bemonsteringen zijn ook gravimetrische watergehaltes in de monsters voor de lagen 0-30, 30-60 en 60-90 cm bepaald (Tabel 3-7). Hierbij is geen rekening gehouden met de ligging/diepte van de aanwezige verdichte laag. Bemonsteringen hebben voorafgaand en na afloop van het groeiseizoen plaatsgevonden in de jaren 2018, 2019 en 2020, waarbij meerdere plots zijn bemonsterd. Over het algemeen is na afloop van het groeiseizoen de bodem over de gehele bemonsterde diepte $(0-90 \mathrm{~cm})$ droger dan in het bijbehorende voorjaar. Op het oog zijn de verschillen tussen de plots gering. Voor 2020 waren per bemonsteringsdiepte de paarsgewijze verschillen tussen de vier behandelingen (gewassen) niet significant.

Tabel 3-7 Gravimetrisch watergehalte als functie van de diepte ten tijde van de N-mineraal bemonsteringen in voorjaar en najaar van de jaren 2018, 2019 en 2020. NB In voorjaar 2020 is alleen een overall gemiddeld watergehalte in de lagen 0-30 en $30-60 \mathrm{~cm}$ bepaald.

\begin{tabular}{|c|c|c|c|c|c|c|c|c|}
\hline \multirow{2}{*}{$\begin{array}{l}\text { Laag } \\
(\mathrm{cm}-\mathrm{mv})\end{array}$} & \multicolumn{2}{|l|}{2018} & \multicolumn{2}{|l|}{2019} & \multicolumn{4}{|l|}{2020} \\
\hline & M1 & $\mathbf{S 2}$ & M1 & 52 & M1 & S1 & 52 & S3 \\
\hline \multicolumn{9}{|l|}{ Voorjaar } \\
\hline $30-60$ & 0,158 & 0,158 & 0,150 & 0,145 & 0,179 & 0,179 & 0,179 & 0,179 \\
\hline $60-90$ & 0,171 & 0,181 & 0,159 & 0,164 & n.d. & n.d. & n.d. & n.d. \\
\hline $0-30$ & 0,067 & 0,063 & 0,104 & 0,094 & 0,093 & 0,089 & 0,095 & 0,084 \\
\hline $30-60$ & 0,057 & 0,054 & 0,091 & 0,091 & 0,065 & 0,062 & 0,068 & 0,058 \\
\hline $60-90$ & 0,107 & 0,102 & 0,129 & 0,117 & 0,102 & 0,111 & 0,121 & 0,096 \\
\hline
\end{tabular}

n.d.: niet gemeten

\subsection{Gewas}

\subsubsection{Bovengrondse opbrengst}

In 2017 had de maisbehandeling de hoogste drogestofopbrengst, zetmeelgehalte en -opbrengst en VCOS (Tabel 3-8). De afrijping, te zien aan het drogestofgehalte, was het verst bij mais en $\mathrm{C} 1$ en het minst ver bij C7. Alleen het $\mathrm{N}$-gehalte van mais was significant lager dan de overige behandelingen. De $\mathrm{N}$-opbrengst verschilde echter niet significant tussen de behandeling. Piper had significant het laagste zetmeelgehalte en VCOS, wat te verwachten was, aangezien Piper een structuurtype van sorghum is, terwijl C1 en C7 graantypes zijn. C1 scoorde hoog met hogere drogestof- en zetmeelopbrengsten dan de overige sorghumrassen en de hoogste $\mathrm{N}$-opbrengst, hoewel niet significant, van alle vier de behandelingen.

Mais toonde in 2018 opnieuw hogere opbrengsten dan C7 (Tabel 3-9), maar in beide gewassen was de opbrengst in dit droge jaar zeer laag. Bij de zaai was de bovengrond al droog, terwijl de ondergrond nog vochtig was. C7 leek in het begin meer last van de droogte te hebben dan mais, mogelijk door het kleinere zaad (minder eigen reserves). Daarnaast heeft sorghum een trage beginontwikkeling waardoor het in het begin vermoedelijk ook minder wortelontwikkeling en dus toegang tot water had dan de maisplanten. Het proefveld was eind juli een keer beregend door de veehouder, maar door de grote droogte had dit vermoedelijk weinig effect. Door de droogte zijn de maisplanten relatief vroeg gaan afrijpen en afsterven, terwijl C7 aan het einde van de zomer nieuwe uitlopers aanmaakte. Ten tijde van de oogst eind september hadden deze uitlopers pluimen in bloei (nog geen zaadzetting). Dit is een verklaring voor de zeer lage zetmeelgehaltes van C7. Daarnaast was door de niet volledige afrijping van de jonge sorghumscheuten het suikergehalte relatief hoog en was het drogestofgehalte laag. Ook de verteringscoëfficiënt van de organische stof was bij sorghum lager, maar in vergelijking met 2017 was het verschil met mais kleiner. Ook dit heeft vermoedelijk met de relatief goed verteerbare nieuwe uitlopers bij de sorghum te maken. Er was geen verschil voor N-gehalte, maar de $\mathrm{N}$-opbrengst was hoger voor mais. 
Ook 2019 was een zeer droog jaar. Op een aantal fronten deed C7 het beter dan in 2018 (hogere drogestof-, zetmeel- en N-gehaltes), terwijl mais een zeer slechte kolfzetting had als gevolg van extreme droogte op het kritieke moment rond de bloei. Hierdoor waren de drogestof- en zetmeelgehaltes zeer laag, evenals de VCOS (Tabel 3-10). Het lijkt erop dat C7 veel suiker had omgezet in zetmeel ten tijde van de oogst in 2019, terwijl dit niet gebeurd was in 2018 .

Ook in 2020 had C7 lagere opbrengsten ten opzichte van mais (Tabel 3-11). De twee maisbehandelingen (met drie jaar mais als voorvrucht en met drie jaar sorghum als voorvrucht) hadden alleen een lager suikergehalte dan de twee sorghumbehandelingen (duidt op verdere afrijping), maar hadden over het algemeen hogere waardes voor de overige opbrengstparameters. Opvallend is dat mais na drie jaar sorghum op alle opbrengstparameters hogere gemiddelden toont dan continu mais. Hoewel dit effect nergens significant was, zou het kunnen wijzen op een licht positief effect van vruchtwisseling op de maisopbrengst. Suzy, een structuurtype sorghum net als Piper in 2017, liet lage zetmeelgehaltes en VCOS zien in vergelijking met C7.

Tabel 3-8 Opbrengsten en voederwaarde van mais en sorghum in 2017.

\begin{tabular}{|c|c|c|c|c|c|c|c|}
\hline Variant & $\begin{array}{l}\text { DS } \\
\left(\mathrm{g} \mathrm{kg}^{-1}\right)\end{array}$ & $\begin{array}{l}\text { DS-opbrengst } \\
(\mathrm{t} \mathrm{ha-1)}\end{array}$ & $\begin{array}{l}\text { Zetmeel } \\
\left(\mathrm{g} \mathrm{kg}^{-1}\right)\end{array}$ & $\begin{array}{l}\text { Zetmeelopbrengst } \\
\left(\mathrm{t} \mathrm{ha} \mathrm{a}^{-1}\right)\end{array}$ & $\begin{array}{l}N \\
\left(g_{k g}^{-1}\right)\end{array}$ & $\begin{array}{l}\text { N-opbrengst } \\
\left(\mathrm{kg} \mathrm{ha}^{-1}\right)\end{array}$ & $\begin{array}{l}\text { veos } \\
(\%)\end{array}$ \\
\hline Mais & 359 a & 20,0 a & $340 \mathrm{a}$ & $6,8 \mathrm{a}$ & $9,9 \mathrm{c}$ & 199 & 74 a \\
\hline C7 & $238 c$ & $12,7 \mathrm{~b}$ & $159 \mathrm{c}$ & $2,0 \mathrm{c}$ & $12,6 \mathrm{~b}$ & 159 & $61 \mathrm{~b}$ \\
\hline Piper & $274 b$ & $13,3 \mathrm{~b}$ & $65 d$ & $0,9 \mathrm{c}$ & $13,0 \mathrm{~b}$ & 176 & $53 c$ \\
\hline LSD $5 \% \$$ & 34 & 2,9 & 43 & 1,4 & 1,7 & & 2 \\
\hline
\end{tabular}

$\$$ : indien de P-waarde $>0.05$ wordt geen LSD-waarde vermeld.

Tabel 3-9 Opbrengsten en voederwaarde van mais en sorghum in 2018.

\begin{tabular}{|c|c|c|c|c|c|c|c|c|}
\hline Variant & $\begin{array}{l}\text { DS } \\
\left(\mathrm{g} \mathrm{kg}^{-1}\right)\end{array}$ & 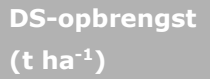 & $\begin{array}{l}\text { Suiker } \\
\left(\mathrm{g} \mathrm{kg}^{-1}\right)\end{array}$ & $\begin{array}{l}\text { Zetmeel } \\
\left(\mathrm{g} \mathrm{kg}^{-1}\right)\end{array}$ & $\begin{array}{l}\text { Zetmeelopbrengst } \\
\left(\mathrm{t} \mathrm{ha}^{-1} \text { ) }\right.\end{array}$ & $\begin{array}{l}\text { N } \\
\left(\mathrm{g} \mathrm{kg}^{-1}\right)\end{array}$ & $\begin{array}{l}\text { N-opbrengst } \\
\left(\mathrm{kg} \mathrm{ha}^{-1}\right)\end{array}$ & $\begin{array}{l}\text { veos } \\
(\%)\end{array}$ \\
\hline Mais & 355 & 11,4 & 175 & 257 & 2,9 & 15,7 & 178 & 79,1 \\
\hline P-waarde & $<, 001$ & 0,038 & 0,239 & 0,008 & 0,002 & 0,344 & 0,002 & $<, 001$ \\
\hline
\end{tabular}

Tabel 3-10 Opbrengsten en voederwaarde van mais en sorghum in 2019.

\begin{tabular}{|c|c|c|c|c|c|c|c|c|}
\hline Variant & $\begin{array}{l}\text { DS } \\
\left(\mathrm{g} \mathrm{kg}^{-1}\right)\end{array}$ & 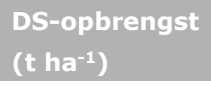 & $\begin{array}{l}\text { Suiker } \\
\left(\mathrm{g} \mathrm{kg}^{-1}\right)\end{array}$ & $\begin{array}{l}\text { Zetmeel } \\
\left(\mathrm{g} \mathrm{kg}^{-1}\right)\end{array}$ & $\begin{array}{l}\text { Zetmeelopbrengst } \\
\text { (t ha-1) }\end{array}$ & $\begin{array}{l}\text { N } \\
\left(\mathrm{g} \mathrm{kg}^{-1}\right)\end{array}$ & $\begin{array}{l}\text { N-opbrengst } \\
\left(\mathrm{kg} \mathrm{ha}^{-1}\right)\end{array}$ & $\begin{array}{l}\text { veos } \\
(\%)\end{array}$ \\
\hline Mais & 287 & 11,3 & 201 & 143 & 1,6 & 14,4 & 163 & 77,6 \\
\hline P-waarde & 0,56 & 0,03 & 0,01 & 0,1 & 0,40 & 0,02 & 0,06 & 0,11 \\
\hline
\end{tabular}


Tabel 3-11 Opbrengsten en voederwaarde van mais en sorghum in 2020. In 2020 waren er twee behandelingen met mais. Mais na mais had drie jaar mais als voorvrucht en mais na sorghum had drie jaar sorghum als voorvrucht.

\begin{tabular}{|c|c|c|c|c|c|c|c|c|}
\hline Variant & $\begin{array}{l}\text { DS } \\
\left(\mathrm{g} \mathrm{kg}^{-1}\right)\end{array}$ & $\begin{array}{l}\text { DS-opbrengst } \\
(\mathrm{t} \mathrm{ha-1})\end{array}$ & $\begin{array}{l}\text { Suiker } \\
\left(\mathrm{g} \mathrm{kg}^{-1}\right)\end{array}$ & $\begin{array}{l}\text { Zetmeel } \\
\left(\mathrm{g} \mathrm{kg}^{-1}\right)\end{array}$ & 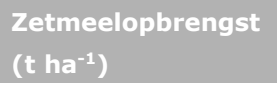 & $\begin{array}{l}N \\
\left(g_{k g}^{-1}\right)\end{array}$ & $\begin{array}{l}\text { N-opbrengst } \\
\left(\mathrm{kg} \mathrm{ha}^{-1}\right)\end{array}$ & $\begin{array}{l}\text { Vcos } \\
(\%)\end{array}$ \\
\hline Mais na mais & 459 a & $13,4 \mathrm{a}$ & $32 \mathrm{~b}$ & $371 a b$ & $5,0 \mathrm{a}$ & 10,4 & $140 a b$ & $77 a b$ \\
\hline C7 & $355 c$ & $7,0 \mathrm{~b}$ & $78 \mathrm{a}$ & 292 b & $2,1 \mathrm{~b}$ & 12,7 & $90 \mathrm{c}$ & $73 \mathrm{~b}$ \\
\hline Suzy & $385 \mathrm{~b}$ & $9,8 \mathrm{~b}$ & $60 a$ & $133 c$ & $1,3 \mathrm{~b}$ & 11,8 & $118 \mathrm{bc}$ & $61 c$ \\
\hline LSD $5 \%{ }^{\$}$ & 20 & 2,9 & 22 & 90 & 1,6 & & 42 & 5 \\
\hline
\end{tabular}

$\$$ : indien de P-waarde $>0.05$ wordt geen LSD-waarde vermeld.

In mei 2020 was tevens de opbrengst van de groenbemester bepaald. Er was geen significant effect van voorvrucht (de sorghum- en maisbehandelingen) op het drogestofgehalte en de drogestofopbrengst van de groenbemester (Tabel 3-12).

\section{Samenvattend}

Samenvattend had mais consistent een hogere drogestofopbrengst dan de geteste sorghumrassen, ook in 2018 en 2019, na een heel droog groeiseizoen. De zetmeel- en stikstofopbrengst waren doorgaans ook hoger voor mais. Sorghum lijkt nadeel te hebben gehad van droogte in de beginontwikkeling, doordat het gewas zich op dat moment sowieso trager dan mais ontwikkelt. Echter lijkt sorghum een voordeel te hebben ten opzichte van mais bij droogte rondom de bloeiperiode, aangezien sorghum zaadzetting kan uitstellen. De structuurtypes Piper en Suzy hadden een zeer lage zetmeelopbrengst. Verder lijkt er een klein, niet significant effect te zijn van een sorghum-voorvrucht op de opbrengst van mais.

Tabel 3-12 Drogestofgehalte en -opbrengst van de groenbemester (gerst) in 2020, geoogst op 6 mei.

\begin{tabular}{lll} 
Voorvrucht & DS & \multicolumn{1}{c}{$\begin{array}{l}\text { DS opbrengst } \\
(\mathrm{t} \mathrm{ha-1})\end{array}$} \\
\hline Mais (M1) & 240 & 1.27 \\
\hline C7 (S1) & 225 & 1.18 \\
\hline C7 (S2) & 227 & 1.27 \\
\hline C7 (S3) & 224 & 1.29 \\
\hline P-waarde & 0.45 & 0.77 \\
\hline LSD 5\% & & \\
\hline
\end{tabular}

$\$$ : indien de P-waarde > 0.05 wordt geen LSD-waarde vermeld.

\subsubsection{LAI en gewashoogte}

Mais en sorghum zijn op hetzelfde moment gezaaid. Beide planten ontwikkelen zich op een andere manier, waarbij mais duidelijk hoger wordt dan sorghum (Figuur 3-11a). In termen van LAI zijn de verschillen veel kleiner (Figuur 3-11b). Omdat de verdampingsvraag voor een groot deel gestuurd wordt door de LAI, betekent dit dat deze dus niet erg verschillend zal zijn geweest tussen de gewassen. De maximale LAI voor mais is relatief laag. Nguy-Robertson et al. (2012) laten zien dat de maximale (groene) LAI voor mais varieert per jaar en per mais hybride tussen 3,9 en 6,3 $\mathrm{m}^{2} \mathrm{~m}^{-2}$. Hier was de range 2-4,5 $\mathrm{m}^{2} \mathrm{~m}^{-2}$. Mogelijk dat deze lage waarden een eigenschap zijn van de speciale mais hybride die in dit experiment is gebruikt (LG 30.209). Dit maisras kent een zeer kort groeiseizoen, zodat het gelijktijdig met de sorghum gezaaid en geoogst kon worden. Bhatt (1995) presenteerde maximum LAI voor sorghum in de range van 1.7 tot 5.1, afhankelijk van plantdichtheid (2-20 planten per $\mathrm{m}^{2}$ ); de hoogste LAI werd gemeten bij 15 planten per $\mathrm{m}^{2}$, wat iets lager is dan hier gebruikt. 
Aan het eind van 2020 zijn voor alle herhalingen van de vier behandelingen (mais na mais, mais na sorghum, sorghum C7, sorghum Suzy) de gewashoogten en LAI gemeten om een indruk te krijgen van de spreiding tussen de herhalingen (Figuur 3-12). Hieruit valt af te leiden dat de waarnemingen in de standaard doorgemeten plots 2 (sorghum Suzy), 6 (mais) en 7 (sorghum C7) niet afwijken van de overige herhalingen van deze behandelingen. Dus het is aannemelijk dat de getoonde patronen als functie van tijd (Figuur 3-11) ook in de herhalingen aanwezig zullen zijn geweest.

De gemiddelde gewashoogte van Suzy was gelijk aan beide maisbehandelingen, maar C7 was aanzienlijk kleiner (Tabel 3-13). Dit resulteerde echter niet in een kleinere LAI voor C7 die niet significant verschilde van de gemiddelde LAI van beide maisbehandelingen, alleen Suzy had een hogere gemiddelde LAI.

De verschillen tussen de gewassen tijdens groeiseizoen 2020 zijn via foto's te zien in Figuur 3-13.

\section{Samenvattend}

Mais en sorghum ontwikkelen zich verschillend in de tijd. Dit uit zich vooral in verschil in gewashoogte op gelijke momenten in het groeiseizoen. De verschillen in bladoppervlakte-index (LAI) zijn geringer.

a)

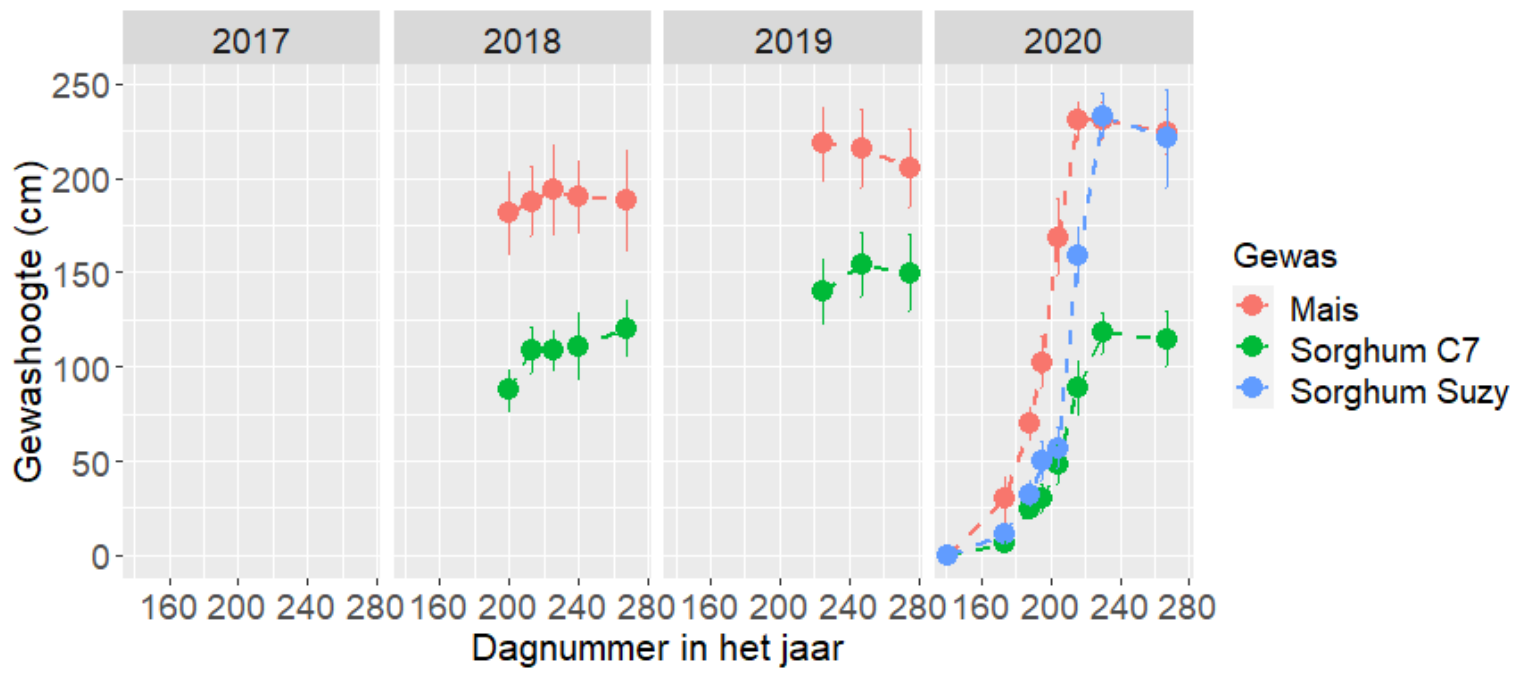

b)

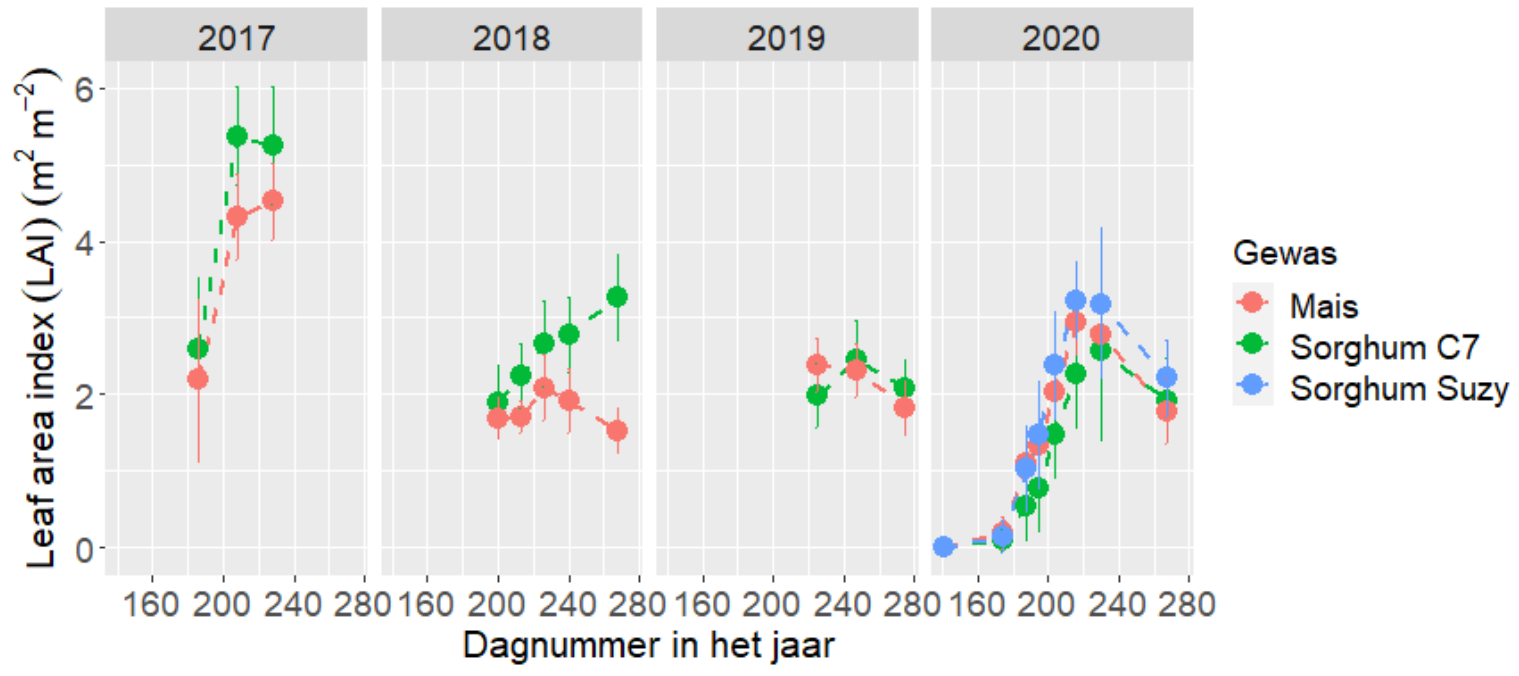

Figuur 3-11 Gewashoogte (a) en leaf area index LAI (b) voor mais, sorghum C7 en sorghum Suzy als functie van de tijd voor de vier groeiseizoenen 2017-2020. De symbolen zijn gemiddelden van twintig planten en de verticale lijnen stellen \pm standaardafwijking voor. 
a)

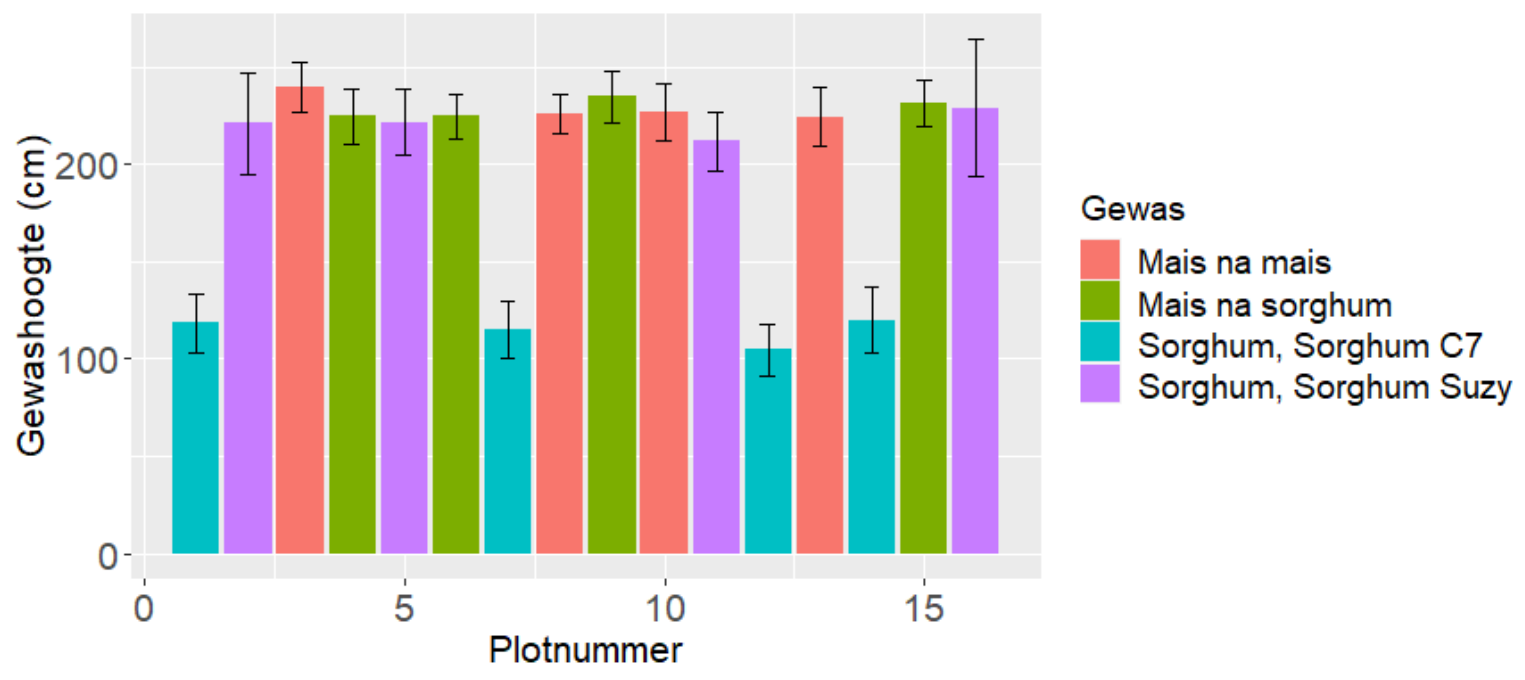

b)

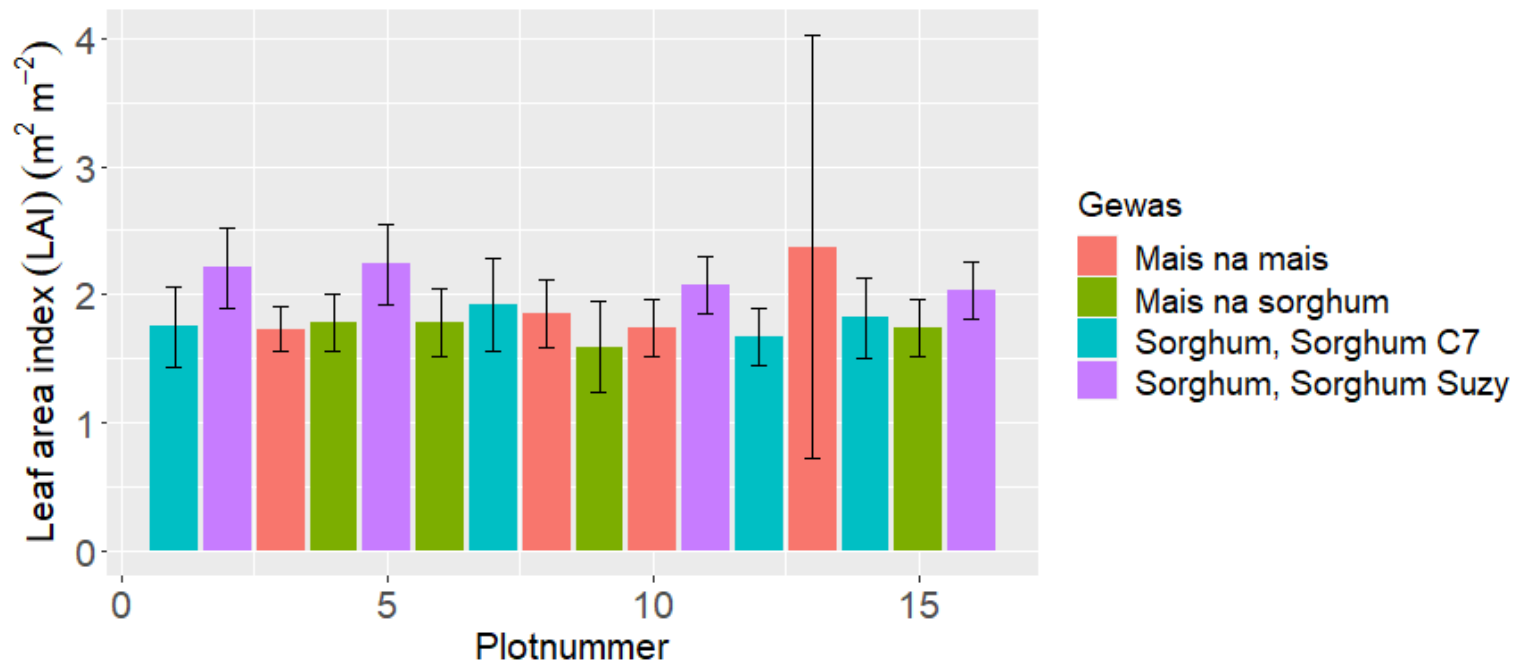

Figuur 3-12 Gewashoogte (a) en leaf area index LAI (b) aan het eind van groeiseizoen 2020 voor alle afzonderlijke plots van de behandelingen mais na mais, mais na sorghum, sorghum $C 7$ en sorghum Suzy. De symbolen zijn gemiddelden van twintig waarnemingen en de verticale lijnen stellen \pm standaardafwijking voor binnen een plot.

Tabel 3-13 Gemiddelde hoogte en leaf area index in 2020.

\begin{tabular}{lll} 
Variant & Gemiddelde hoogte $(\mathrm{cm})$ & Gemiddelde LAI $\left(\mathrm{m}^{2} \mathrm{~m}^{-2}\right)$ \\
Mais na mais & $229 \mathrm{a}$ & $1,7 \mathrm{~b}$ \\
\hline Mais na sorghum & $229 \mathrm{a}$ & $1,9 \mathrm{ab}$ \\
\hline C7 & $114 \mathrm{~b}$ & $1,8 \mathrm{~b}$ \\
\hline Suzy & $221 \mathrm{a}$ & $2,1 \mathrm{a}$ \\
\hline P-waarde & $<0,001$ & 0,027 \\
\hline LSD 5\% & 10,0 & 0,27 \\
\hline
\end{tabular}




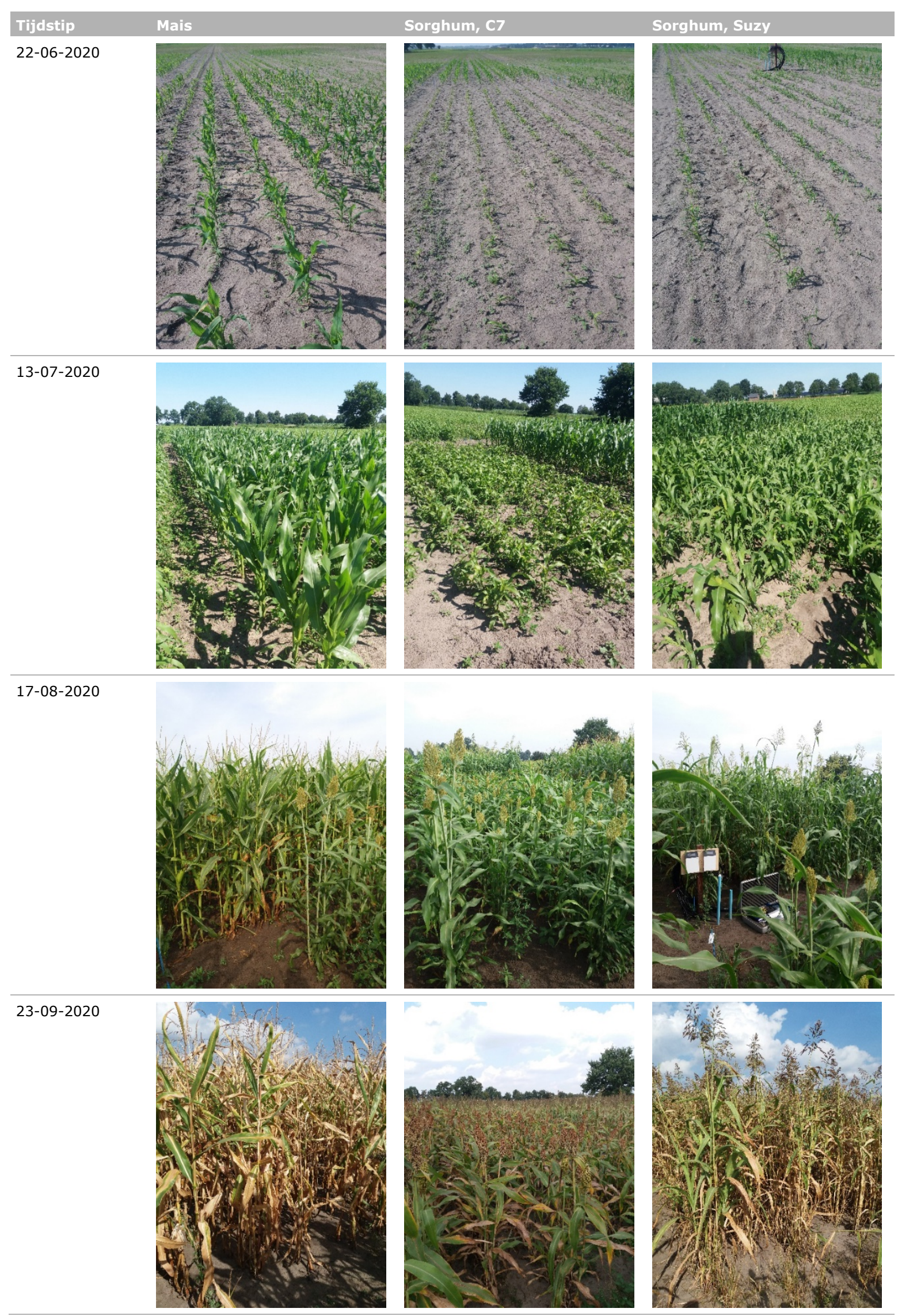

Figuur 3-13 Foto-impressies van de drie gewassen in 2020 voor vier momenten in het groeiseizoen (foto's: Wilma Jans, WENR). 


\subsubsection{Wortelmetingen}

In 2017 en 2019 is de wortelmassa in de rij en in het midden tussen twee rijen bepaald. In 2019 was dit gedaan voor twee behandelingen, namelijk continu mais en C7. In 2020 werd de wortelmassa op $12,5 \mathrm{~cm}$ afstand van de rij bepaald, wat een goede indicatie is voor de gemiddelde wortelmassa op veldniveau.

In 2017 was de wortelmassa in de rij in de bovenste $20 \mathrm{~cm}$ hoger voor C7 dan voor de overige behandelingen, hoewel dit verschil niet significant was in de laag 0-10 cm en niet verder kwam dan een trend in de laag 10-20 cm (Figuur 3-14). Vanaf de laag 20-30 cm was de wortelmassa hoger voor Piper (trend) en dit was significant in de laag 30-40 cm en $40-50 \mathrm{~cm}$. Tussen de rij was de wortelmassa van Piper al vanaf $10-20 \mathrm{~cm}$ hoger (trend in 10-20 cm, significant in de lagen daaronder) (Figuur 3-14). De hogere wortelmassa van Piper in de diepere lagen zou een raseffect (raskenmerk) of een effect van zaaidichtheid kunnen zijn. Bij de andere behandelingen was de wortelmassa van die lagen in de rij versus tussen de rijen niet meer verschillend; het feit dat Piper op een rijafstand van $25 \mathrm{~cm}$ was gezaaid, zou daarom geen verklaring hoeven te zijn. ANOVA's voor de wortelmassa tussen de rijen zonder de behandeling Piper gaven geen significante behandelingseffecten meer.

In 2019 vertoonde mais een significant hogere wortelmassa in de laag 0-10 cm dan C7, wat in tegenstelling staat tot de resultaten uit 2017 (Figuur 3-14). In absolute termen verschilt de wortelmassa van C7 niet veel in de twee jaren, maar is het vooral mais die een bijna verdubbelde wortelmassa vertoont in 2019 in de verschillende lagen in de rij ten opzichte van 2017. Een mogelijke verklaring zou kunnen zijn dat er in het derde proefjaar nog onverteerde dode maiswortels van de voorgaande jaren in de bodem aanwezig waren die als wortelmassa mee zijn gemeten. Tussen de rijen verschillen de wortelmassa's niet significant van elkaar in 2019 (Figuur 3-14), net als in 2017 wanneer Piper niet in de ANOVA's meegenomen werd.

In 2020 werden er geen behandelingseffecten in wortelmassa waargenomen, behalve een trend voor een hogere wortelmassa bij Suzy en mais na mais ten opzichte van C7 en mais na sorghum in de laag van 30-40 cm (Figuur 3-15). De wortellengtedichtheid (WLD) was hoger bij Suzy in de laag $20-30 \mathrm{~cm}$. Wortelmassa en lengtedichtheid waren niet bepaald in de laag 40-50 cm, maar een visuele inspectie van deze laag in alle 16 plots gaf aan dat er nergens wortels meer voorkwamen beneden $40 \mathrm{~cm}$. In de wortelmonsters tot $40 \mathrm{~cm}$ is de wortellengte in drie diameterklassen (fijne, middelfijne en grove wortels) geanalyseerd (Figuur 3-15). In Figuur 3-15 zijn tevens voor de vier behandelingen per bodemlaag van $10 \mathrm{~cm}$ het aandeel grove, middelfijne en fijne wortels weergegeven. Ongeveer $60-75 \%$ van de wortellengte voor alle vier behandelingen viel binnen de diameterklasse fijne wortels $(0-0,5 \mathrm{~mm})$ en grove wortels met een diameter groter dan $2 \mathrm{~mm}$ droegen nauwelijks bij aan de totale wortellengte. Een toetsing van de fractie fijne wortels $(0-0,5 \mathrm{~mm})$ leverde geen significante verschillen op voor zowel de gehele bemonsteringsdiepte als per laag van $10 \mathrm{~cm}$. Er was wel een effect van diepte: in alle behandelingen nam het aandeel fijne wortels toe met de diepte $(P<0,001)$, dus onafhankelijk van het gewas.

\section{Samenvattend}

De sorghum structuurtypes hadden in sommige gevallen een hogere wortelmassa en worteldichtheid in de diepere bodemlagen $(30-50 \mathrm{~cm}$ ) dan mais. In 2017 wortelde Piper ook voorbij de verdichte laag, beginnend op circa $30 \mathrm{~cm}$ diepte. Sorghum C7 vertoonde onder de $10 \mathrm{~cm}$ een vergelijkbare beworteling als mais. Vruchtwisseling had geen effect op de beworteling van mais. 
Wortelmassa in rij 2017

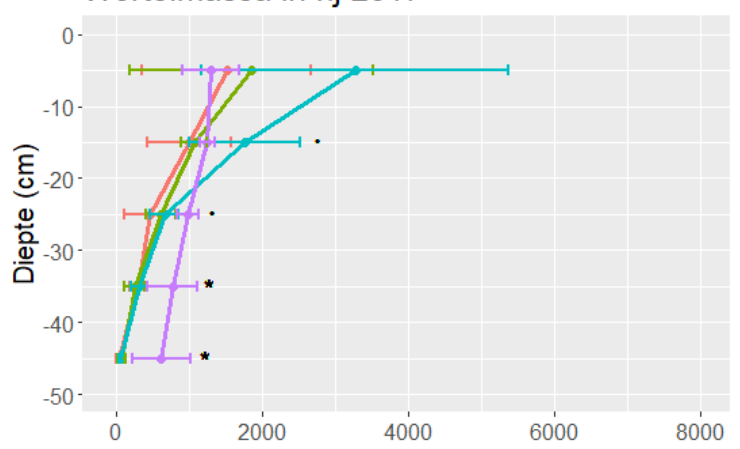

Wortelmassa in rij 2019

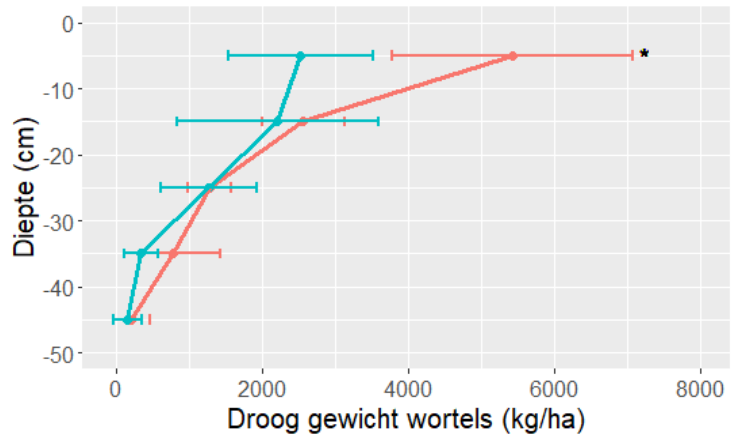

Behandeling $\rightarrow$ Mais $\rightarrow \mathrm{C} 1 \rightarrow \mathrm{C} 7 \rightarrow$ Piper
Wortelmassa tussen rij 2017

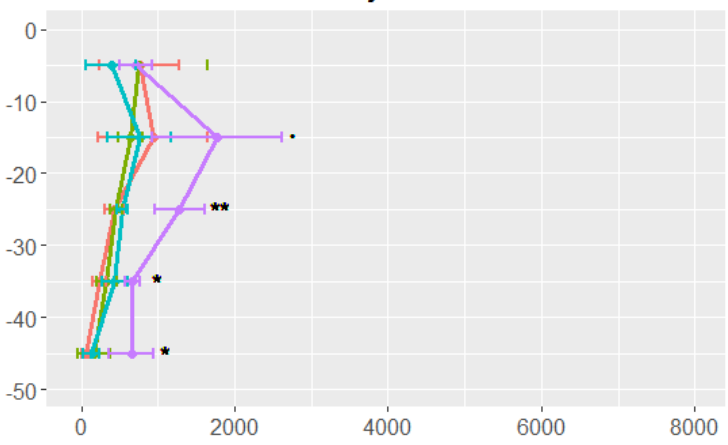

Wortelmassa tussen rij 2019

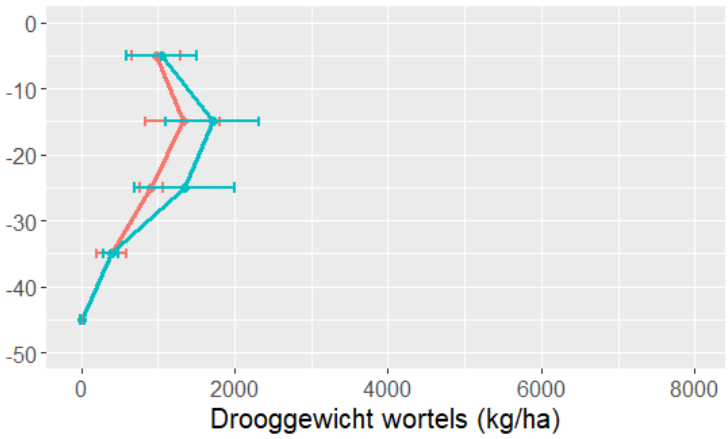

Figuur 3-14 Wortelmassa van sorghum en mais tot $50 \mathrm{~cm}$ diepte, zowel in de rij als midden tussen de rijen, na de oogst in 2017 en 2019. De rijafstand van Piper was afwijkend van de andere behandelingen (zie methoden). De significantie van de behandelingseffect is per bodemlaag aangegeven: **: $P<0,01 ; *$ : $P<0,05 ; .: P<0,1$. De foutenbalken geven + en - de standaarddeviatie weer.
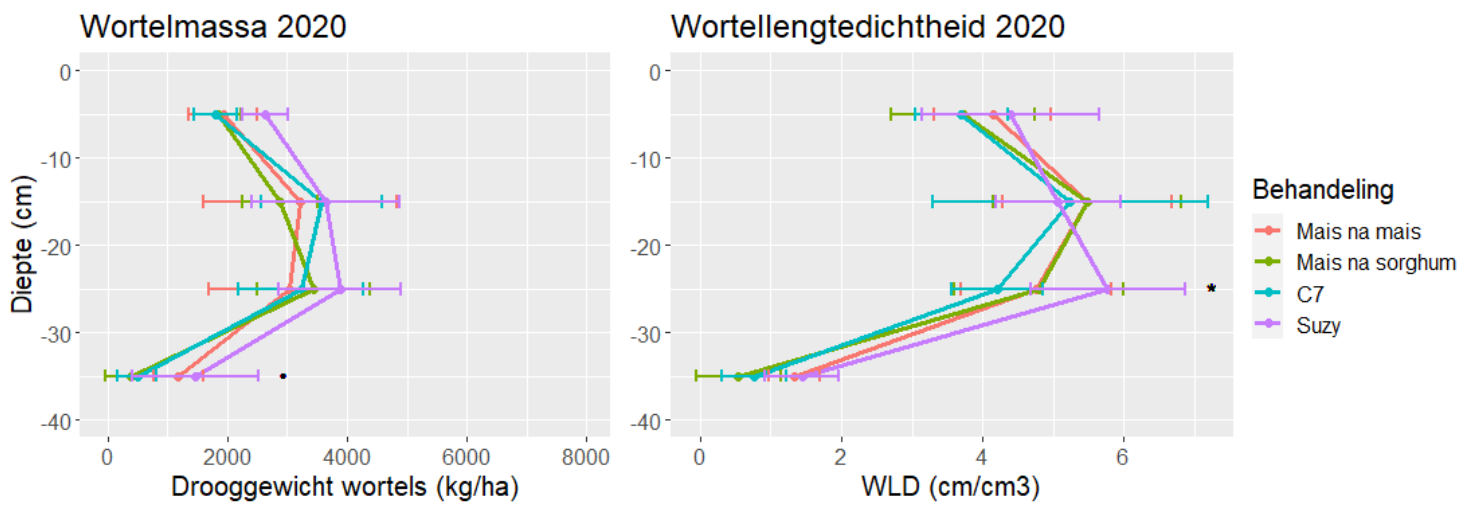

Fractie per diameterklasse

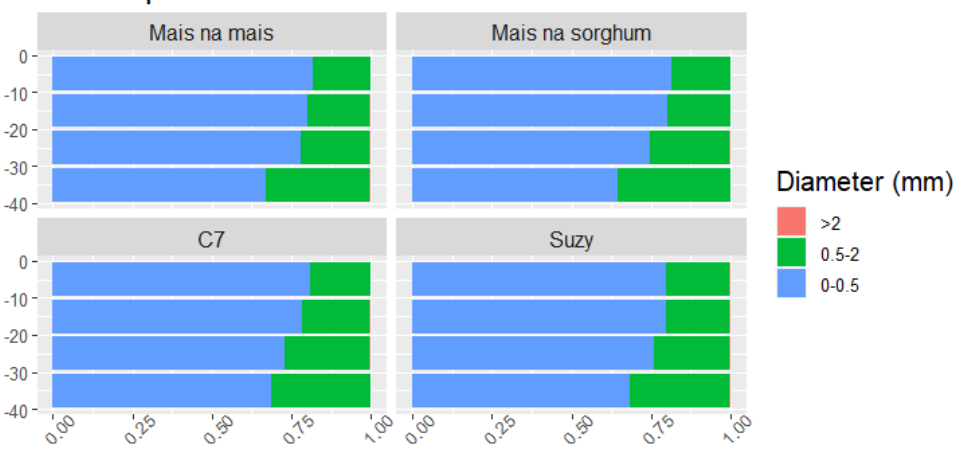

Figuur 3-15 Wortelparameters van twee sorghumrassen (na drie jaar sorghum), van mais na drie jaar mais en van mais na drie jaar sorghum, monsters op 12,5 cm afstand van de rij. De significantie van het behandelingseffect is per bodemlaag aangegeven: *: $P<0,05 ; .: P<0,1$. De foutenbalken geven + en - de standaarddeviatie weer. 


\subsubsection{Bodemstructur en beworteling: visuele beoordeling}

De visuele bodemstructuur- en bewortelingsbeoordeling na de oogst in 2017 bevestigde de diepe en intensieve beworteling van Piper (Tabel 3-14). De andere sorghumrassen C1 en C7 namen een tussenpositie in en mais wortelde het minst diep en intensief. Daarnaast was bij Piper het aandeel kruimels zowel in de laag 0-25 cm als 25-45 cm het hoogst. De intensieve beworteling en kortere rijafstand van Piper ten opzichte van de andere behandelingen zullen hier een rol in hebben gespeeld.

Tabel 3-14 Visuele bodemstructuur beoordeling in 2017.

\begin{tabular}{|c|c|c|c|c|c|c|c|c|}
\hline & & & Kruimel & Afgerond & Scherp & Kruimel & Afgerond & Scherp \\
\hline Variant & Worteldiepte & Beworteling & $0-25 \mathrm{~cm}$ & $0-25 \mathrm{~cm}$ & $0-25 \mathrm{~cm}$ & $25-45 \mathrm{~cm}$ & $25-45 \mathrm{~cm}$ & $25-45 \mathrm{~cm}$ \\
\hline Mais & 37,8 & $4,5 \mathrm{c}$ & $12,5 \mathrm{~b}$ & $10,0 \mathrm{~b}$ & 77,5 a & 2,5 & $10,0 \mathrm{~b}$ & 87,5 a \\
\hline $\mathrm{C7}$ & 41,8 & $5,8 \mathrm{~b}$ & $15,0 \mathrm{~b}$ & $12,5 \mathrm{~b}$ & 72,5 a & 7,5 & $10,0 \mathrm{~b}$ & 82,5 a \\
\hline Piper & 47,3 & $7,5 \mathrm{a}$ & $52,5 \mathrm{a}$ & $22,5 \mathrm{a}$ & $25,0 \mathrm{~b}$ & 15,0 & $22,5 \mathrm{a}$ & $62,5 b$ \\
\hline LSD $5 \% \$$ & 6,5 & 1,0 & 25,4 & 7,1 & 21,6 & & 8,3 & 17,1 \\
\hline
\end{tabular}

$\$$ : indien de P-waarde > 0.05 wordt geen LSD-waarde vermeld.

\section{$3.4 \quad$ Nitraat}

\subsubsection{Voorjaar}

De hoeveelheid $\mathrm{N}$-mineraal die in de bodem werd aangetroffen in het voorjaar, bedroeg in de jaren 2018 en $20202 \mathrm{~kg} \mathrm{ha}^{-1}$ per bemonsterde bodemlaag $(30 \mathrm{~cm})$, overeenkomend met de detectielimiet van de bepaling. In 2019 bedroeg de gemiddelde hoeveelheid $(0-90 \mathrm{~cm}) 27 \mathrm{~kg} \mathrm{ha}^{-1}$ voor behandeling M1 (mais) en $33 \mathrm{~kg} \mathrm{ha}^{-1}$ voor S2 (sorghum C7), waarvan ongeveer de helft in 0-30 cm. In het eerste jaar werd wel een grote hoeveelheid $\mathrm{N}$-mineraal aangetroffen van 132 tot $183 \mathrm{~kg} \mathrm{ha}^{-1}(0-90 \mathrm{~cm})$. Dit was het gevolg van de bemesting die abusievelijk vlak voor de $\mathrm{N}$-mineraalbemonstering had plaatsgevonden en daarnaast ook van de rest-stikstof van de voorvrucht winterwortelen met daarna een groenbemester die vóór de zaai was ondergeploegd.

$\mathrm{Er}$ is geen rekening gehouden met deze resultaten bij de interpretatie van de resultaten van $\mathrm{N}$-mineraal in het najaar, omdat de waarden in het voorjaar vrijwel verwaarloosbaar zijn als mogelijke invloed op de resultaten van het najaar. De grotere hoeveelheid van 2017 was deels het gevolg van de uitgevoerde bemesting die als gevolg van de uitgevoerde behandeling kan worden gezien.

\subsubsection{Najaar}

Voor de interpretatie van de najaarsmetingen van N-mineraal zijn de volgende drie vergelijkingen van belang.

1. In het eerste jaar 2017 werden geen significante verschillen aangetroffen tussen de behandelingen (Tabel 3-15, Figuur 3-16). Er is in dat najaar dus ook geen verschil in N-mineraal aangetoond tussen mais en sorghum. Het gekozen sorghum-ras C7 voor de vervolgjaren had wel de laagste gemiddelde $\mathrm{N}$-mineraalwaarde. Ook het verschil in verdeling van $\mathrm{N}$-mineraal over de lagen tussen de behandelingen bleek gering (Figuur 3-16). Dit is getest onder punt 2 en was niet significant. 
Tabel 3-15 Gemiddelde N-mineraal in totale bemonsterde profiel (0-90 cm-mv) in 2017. De verschillen zijn niet significant.

\begin{tabular}{ll} 
Behandeling & N-mineraal $(0-90 \mathrm{~cm}-\mathrm{mv})\left(\mathrm{kg} \mathrm{ha}^{-1}\right)$ \\
M1, mais & 55,65 \\
\hline S1, sorghum C1 & 55,95 \\
\hline S2, sorghum C7 & 46,05 \\
\hline S3, sorghum piper & 50,25 \\
\hline
\end{tabular}

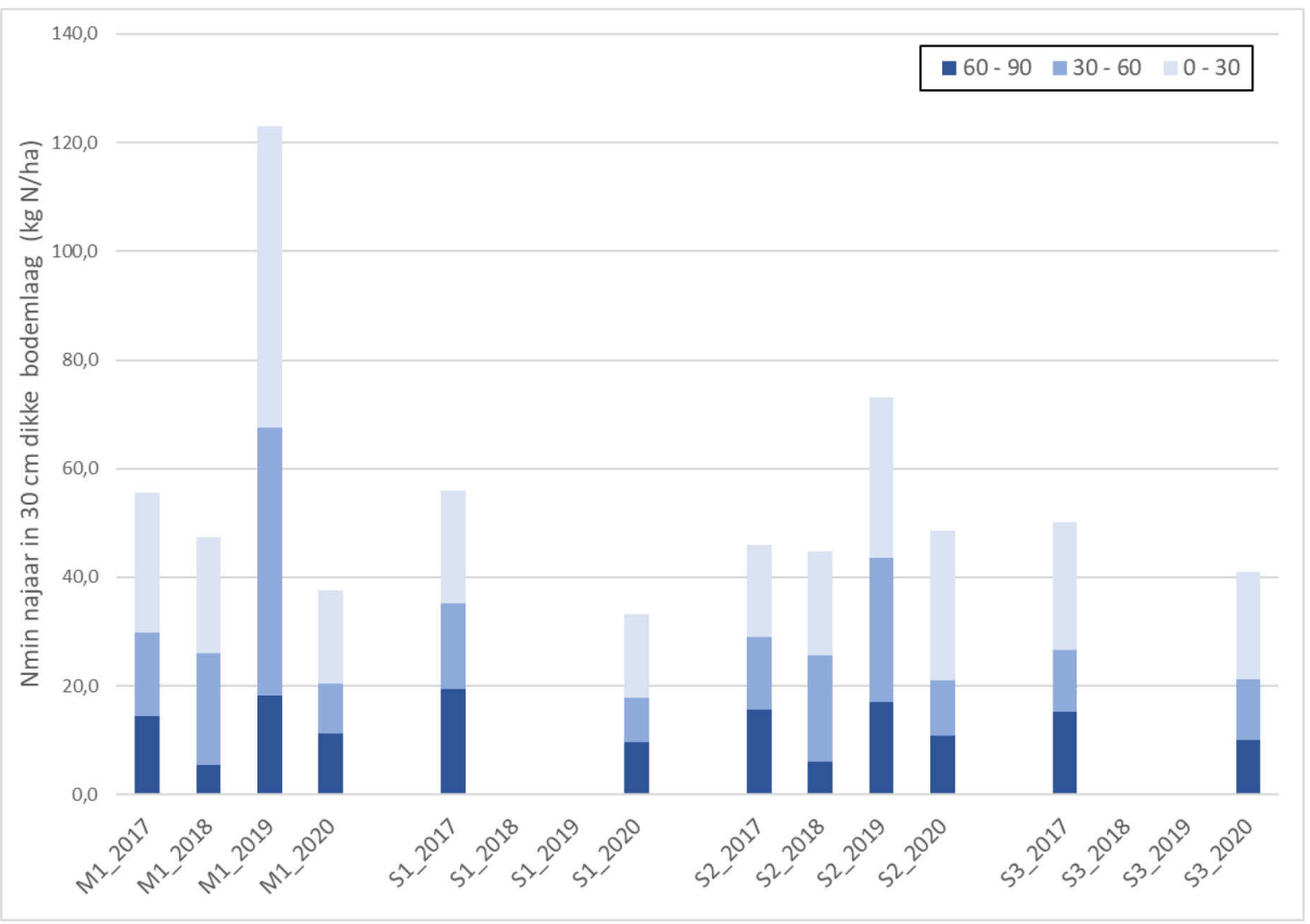

Figuur 3-16 Hoeveelheid N-mineraal in het najaar per behandeling, per jaar en per laag.

2. Voor de vergelijking tussen mais en sorghum is ook een vergelijking van belang tussen de behandelingen M1 en S2 voor alle jaren (Tabel 3-16; Figuur 3-16). Uit de ANOVA blijkt de interactie tussen jaar en behandeling statistisch significant $(p<0.05)$. Gemiddeld over de jaren was $\mathrm{N}$-mineraal in het najaar voor sorghum (S2) bijna $13 \mathrm{~kg} \mathrm{~N}^{-1}$ lager dan voor mais (M1). Dit verschil is alleen in 2019 significant (Tabel 3-16: b-c). In het jaar 2020 is het verschil andersom, maar dit is niet significant (Tabel 3-16: a-a). In het najaar van 2019 is $\mathrm{N}$-mineraal significant hoger dan in de andere jaren, mogelijk als gevolg van een slechtere $\mathrm{N}$-benutting door droogte. Er was geen significant effect van behandeling op de verdeling van $\mathrm{N}$-mineraal over het profiel (Tabel 3-17; Figuur 3-16). De interactie tussen lagen en jaren was wel significant (Tabel 3-18), maar niet relevant voor het doel van deze proef.

3. Ten slotte is de vergelijking van de behandelingen in het laatste jaar relevant (Tabel 3-19; Figuur 3-17). De hoeveelheid $\mathrm{N}$-mineraal in het najaar van 2020 verschilt niet significant tussen de behandelingen. Ook het verschil in verdeling van $\mathrm{N}$-mineraal tussen de lagen bleek gering (Figuur 3-17; vorige punt). 
Tabel 3-16 Gemiddelde $\mathrm{N}$-mineraal $(0-90 \mathrm{~cm}-\mathrm{mv})$ in $\mathrm{kg} \mathrm{ha}^{-1}$ in het najaar per behandeling en jaar. Cijfers met een gelijk lettersymbool zijn niet significant verschillend volgens de Fisher-test.

\begin{tabular}{|c|c|c|c|c|c|}
\hline \multirow[b]{2}{*}{ Behandeling } & \multicolumn{4}{|l|}{ Jaar } & \multirow[b]{2}{*}{ Gemiddeld } \\
\hline & 2017 & 2018 & 2019 & 2020 & \\
\hline M1, mais & $55,7 \mathrm{ab}$ & $47,4 \mathrm{a}$ & $123,0 \mathrm{c}$ & 37,5 a & 65,9 \\
\hline Gemiddeld & 50,8 & 46,0 & 98,0 & 43,0 & 59,5 \\
\hline
\end{tabular}

Tabel 3-17 Gemiddelde aandeel van ieder laag $(30 \mathrm{~cm})$ in het totaal $(0-90 \mathrm{~cm})$ van N-mineraal in het najaar ( $\mathrm{kg} \mathrm{ha}^{-1}$ ) per behandeling, in 2020. De LSD per behandeling is 0,045 en voor de interactie 0,063 .

\begin{tabular}{llll} 
& \multicolumn{2}{l}{ Laag $(\mathrm{cm}-\mathrm{mv})$} & $60-90$ \\
\cline { 2 - 4 } Behandeling & $0-30$ & $30-60$ & 0,21 \\
M1, mais & 0,46 & 0,34 & 0,24 \\
\hline S2, sorghum C7 & 0,43 & 0,33 & 0,22 \\
\hline Gemiddeld & 0,44 & 0,33 & \\
\hline
\end{tabular}

Tabel 3-18 Gemiddelde aandeel van iedere laag $(30 \mathrm{~cm})$ in het totaal $(0-90 \mathrm{~cm})$ van N-mineraal in het najaar ( $\mathrm{kg} \mathrm{ha}^{-1}$ ) per behandeling, in 2020. Cijfers met een gelijk lettersymbool zijn niet significant verschillend volgens de Fisher-test.

\begin{tabular}{llll} 
& Laag $(\mathrm{cm}-\mathrm{mv})$ & $60-90$ \\
\cline { 2 - 4 } Jaar & $0-30$ & $30-60$ & $0,30 \mathrm{c}$ \\
\hline 2017 & $0,41 \mathrm{~d}$ & $0,29 \mathrm{c}$ & $0,14 \mathrm{a}$ \\
\hline 2018 & $0,44 \mathrm{de}$ & $0,43 \mathrm{de}$ & $0,19 \mathrm{ab}$ \\
\hline 2019 & $0,43 \mathrm{de}$ & $0,38 \mathrm{~d}$ & $0,27 \mathrm{c}$ \\
\hline 2020 & $0,49 \mathrm{e}$ & $0,24 \mathrm{bc}$ & 0,22 \\
\hline
\end{tabular}

Tabel 3-19 Gemiddelde N-mineraal in het najaar van 2020 per behandeling. De verschillen zijn niet significant.

\begin{tabular}{ll} 
Behandeling & $\mathrm{N}$-mineraal $(0-90 \mathrm{~cm}-\mathrm{mv})(\mathrm{kg} \mathrm{ha}-1)$ \\
M1, mais & 37,50 \\
\hline S1, mais na sorghum & 33,25 \\
\hline S2, sorghum C7 & 48,50 \\
\hline S3, sorghum Suzy & 41,00 \\
\hline
\end{tabular}

\section{Samenvattend}

Sorghum liet in het najaar gemiddeld $13 \mathrm{~kg} \mathrm{ha}^{-1}$ minder $\mathrm{N}$-mineraal achter in het bemonsterde profiel van 0-90 cm -mv. In een enkel jaar was dit effect veel groter $\left(50 \mathrm{~kg} \mathrm{~N} \mathrm{ha}^{-1}\right)$. Sorghum had ten opzichte van mais geen significant effect op de verdeling van $\mathrm{N}$-mineraal over de bodemlagen. 


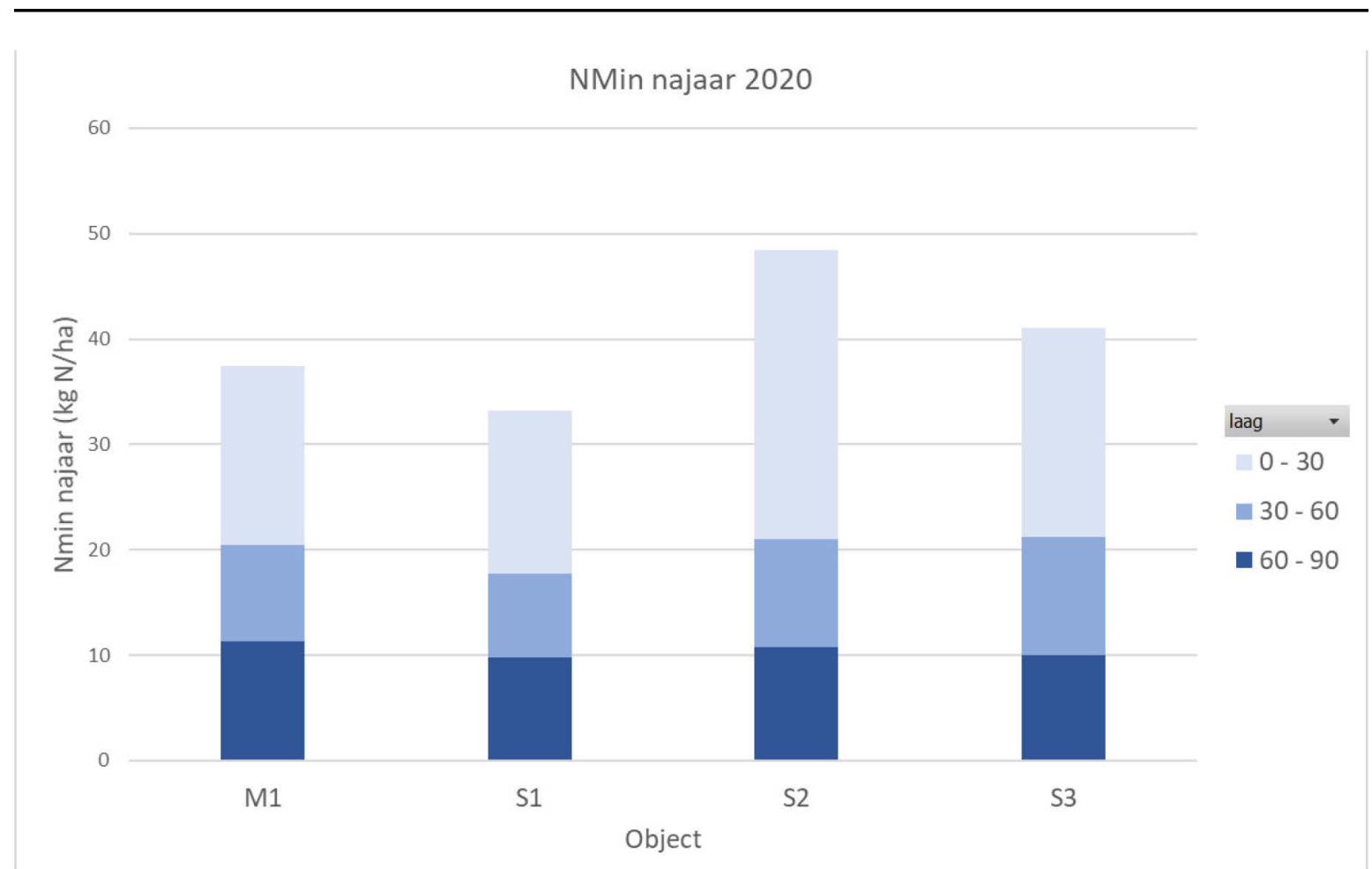

Figuur 3-17 Hoeveelheid N-mineraal in 2020, per behandeling en per laag. 


\section{$4 \quad$ Algemene discussie, conclusie en aanbevelingen}

\subsection{Algemene discussie}

Een belangrijk doel van de proef was om te onderzoeken of sorghum beter in een verdichte ondergrond kan wortelen dan maïs, en daarmee beter gebruik zou maken van het water en stikstof in de ondergrond. Ook zou sorghum onder droge omstandigheden hierdoor beter dan mais in staat zijn om te groeien en de bovengrondse productie op peil te houden. Daarnaast zou de sorghum door die beworteling in de ondergrond de mogelijkheden voor beworteling van snijmais als volggewas kunnen verbeteren. Voor het onderzoek is gezocht naar een droge zandgrond met een duidelijk verdichte ondergrond. Uit de bodemfysische metingen blijkt dat de ondergrond met dichtheden van 1,67 tot $1,69 \mathrm{~g} \mathrm{~cm}^{-3}$ en indringingsweerstanden van meer dan $3 \mathrm{MPa}$ inderdaad zeer verdicht is. Deze ondergrond begint op circa 35-40 cm -mv. Voor de meeste planten en zeker ook voor snijmais houdt dit in dat de bewortelingsdiepte zich beperkt tot de bouwvoor. De zandgrond was wel minder droog dan bedoeld. Uit het bodemonderzoek bleek dat de grondwatertrap niet Gt V, maar Gt III was. Grondwatertrap Gt III geeft aan dat de zomergrondwaterstand meestal niet onder de 1,20 m diepte komt. Bij Gt V komt de zomergrondwaterstand vaak onder de 1,20 m diepte. Dit houdt in dat dit profiel feitelijk niet echt droogtegevoelig is. Echter, met name 2018, maar ook 2019 en 2020 waren relatief droog waarbij de zomergrondwaterstand toch onder de 1,20 m diepte dook. Alleen 2017 was duidelijk natter en kwam de grondwaterstand niet onder de 1,10 m diepte. De verwachting was dat zeker in een droog jaar als 2018, maar ook in 2019 en 2020 de sorghum tot in de ondergrond zou gaan wortelen om voldoende water ter beschikking te hebben.

De hypothese dat sorghum dieper wortelt en een fijner wortelstelsel heeft dan mais, waardoor het efficiënter met water (en stikstof) om kan gaan en beter bestand is tegen droogte, is gebaseerd op buitenlandse metingen (Schittenhelm \& Schroetter, 2014). In dit onderzoek in Nederland zien we echter dat de opbrengst van de geteste sorghumrassen substantieel lager was dan van mais, zowel in jaren met voor Nederlandse begrippen extreme droogte als in jaren zonder watertekort. Dit lijkt tegenstrijdig met de genoemde studies waarin sorghum onder droge omstandigheden een kleinere relatieve afname in opbrengst vertoonde dan mais (zie bijvoorbeeld de Duitse studie van Schittenhelm \& Schroetter, 2014). In deze Duitse studie had rastype sweet sorghum meer wortels (zowel in lengte als gewicht) in de diepe bodemlagen $(40-100 \mathrm{~cm}$ ) dan mais. Onder invloed van droogte namen de wortellengte en -massa van mais en sorghum in de bovenste $40 \mathrm{~cm}$ af, echter verhoogde sweet sorghum gelijktijdig zijn wortellengte en -massa op diepte, terwijl mais dit niet deed. De sweet sorghum had hierbij significant meer wortels in een zeer dichte laag $\left(1,8 \mathrm{~g} \mathrm{~cm}^{-3}\right)$ op een diepte van 60 tot $90 \mathrm{~cm}$ (Schittenhelm, 2010; Schittenhelm \& Schroetter, 2014). Het betreft in die studie een lemige zandgrond met een grondwaterstand op 10 meter diepte (Schittenhelm, 2010). Meer wortels tot 1 meter diepte resulteert in een betere exploratie van bodemvocht in dit hangwaterprofiel. Hierdoor had in de Duitse studie sweet sorghum meer toegang tot water en kon het de bovengrondse productie beter handhaven tijdens droogte ten opzichte van mais (verlaging van droge stofopbrengst van 23,5 naar $11,4 \mathrm{t} \mathrm{ha}^{-1}$ voor mais, van 22,9 naar 14,5 voor rastype sweet sorghum en van 18,1 naar 11,7 voor een sorghum-sudangras hybride). Dat we dit niet terugzagen in onze vierjarige proef zou te maken kunnen hebben met de volgende aspecten: 1) dat de rassen die gebruikt zijn in de proef te Odiliapeel niet tot het type sweet sorghum behoorden, dat zowel een hogere opbrengst, droogteresistentie als bewortelingsdichtheid vertoont (Schittenhelm \& Schoetter, 2014) dan het type sorghum in onze studie; 2) dat de sterk verdichte bodem van ons proefveld vanaf circa $40 \mathrm{~cm}-\mathrm{mv}$ beworteling dusdanig heeft belemmerd dat het voor de sorghum uit onze studie niet mogelijk was dieper te wortelen dan de mais. De indringingsweerstand bereikte namelijk rond $35 \mathrm{~cm}$ diepte de waarde van $3 \mathrm{MPa}$, waarbij wortelgroei sterk geremd wordt. De wortelmetingen en -observaties lieten nauwelijks wortelgroei zien onder $40 \mathrm{~cm}-\mathrm{mv}$. Als de droogteresistentie van sorghum deels het gevolg is van wortelgroei op diepte, zou dit een verklaring kunnen zijn waarom dit effect in onze proef niet is waargenomen; 3) dat als gevolg van capillaire aanvoer vanuit de grondwaterstand de noodzaak voor het gewas om dieper te wortelen minder groot was. 
In 2018, 2019 en 2020 was het opvallend dat de opkomst van de sorghum ten opzichte van de snijmais traag op gang kwam en pas na half juni een zeker herstel liet zien. Dit is goed te zien op de foto's in Figuur 3-13. Mogelijke oorzaken zouden kunnen zijn dat de bovenste $5 \mathrm{~cm}$ van de grond te droog was en de kleine zaden van de sorghum daar meer last van hadden dan de veel grotere maiszaden, waardoor zowel de bovengrondse als ondergrondse groei achterbleef. Daarnaast zou ook de bodemtemperatuur een rol kunnen hebben gespeeld. Terwijl snijmais onder andere door veredeling al bij een bodemtemperatuur van $12{ }^{\circ} \mathrm{C}$ kan worden gezaaid, heeft sorghum hiervoor een bodemtemperatuur van $15^{\circ} \mathrm{C}$ nodig. In 2020 is met de tensiometers ook de bodemtemperatuur gemeten. In Figuur 4-1 zijn de bodemtemperaturen op 25 en $50 \mathrm{~cm}$ diepte te zien. Daarnaast zijn in de figuur ook de neerslagsom vanaf 1 april en de gemiddelde dagtemperatuur gegeven. In 2020 is op 18 mei de sorghum gezaaid. De figuur laat zien dat dit inderdaad in een droge periode is gebeurd. Wel was 18 mei op $5 \mathrm{~cm}$ diepte de grond nog vochtig, maar tot begin juni viel geen neerslag. Op het moment dat er regen viel, was er ook een koude periode. Pas vanaf 10 juni kwam de gemiddelde dagtemperatuur en de bodemtemperatuur weer boven de $15^{\circ} \mathrm{C}$ uit. Het is dus plausibel dat de sorghum inderdaad moeite heeft gehad met ontkiemen door eerst een zeer droge periode en later een te lage temperatuur. Deze trage start zal zonder twijfel hebben bijgedragen aan een lagere opbrengst. Ten opzichte van het jaar 2017 met de hoogste opbrengsten van zowel snijmais als sorghum C7, zijn de opbrengsten in 2020 voor de snijmais $67 \%$ en voor de sorghum C7 55\%.

In Figuur 4-2 zijn de neerslagsom en het daggemiddelde van de luchttemperatuur gepresenteerd voor de jaren 2017, 2018 en 2019. In deze jaren zijn geen bodemtemperaturen gemeten. Voor de temperatuur op de zaaidiepte wordt daarom uitgegaan van de daggemiddelde luchttemperatuur. In Tabel 4-1 is een inschatting gegeven van de hoeveelheid vocht in de bouwvoor in het voorjaar (eind maart) en het najaar (begin oktober). Het blijkt dat in 2017 het voorjaar niet bijzonder droog was en vrij warm. Vanaf half mei kwam de luchttemperatuur niet onder de $15{ }^{\circ} \mathrm{C}$. Uit Tabel 4-1 blijkt dat rond het moment van zaaien er $68,4 \mathrm{~mm}$ water in de bouwvoor zat. Alleen midden juni was er een droge periode. Daarna is er voldoende regen gevallen voor de gewasontwikkeling. De gunstige groeiomstandigheden resulteerden bij de snijmais in een hoge drogestofopbrengst van $20 \mathrm{t} / \mathrm{ha}$. Bij de sorghum C7 was de drogestofopbrengst 12,7 t/ha. Voor beide gewassen was dit de beste jaaropbrengst van de vier proefjaren.

Voor de opkomst van sorghum begon het jaar 2018 goed. Begin mei was de neerslagsom circa 75 mm; na de inzaai van de sorghum waren de gemiddelde luchttemperaturen boven de $15^{\circ} \mathrm{C}$ en was er voldoende neerslag. Begin juni begon er wel een lange periode met extreme droogte. Dit resulteerde uiteindelijk in duidelijk lagere gewasopbrengsten dan in 2017. Daarbij was de lagere gewasopbrengst ten opzichte van 2017 bij snijmais 57\% ( $11 \mathrm{t} \mathrm{ha}^{-1} \mathrm{DS}$ ) en bij sorghum C7 65\% (8,3 t ha-1 DS). Hieruit kan worden opgemaakt dat sorghum weliswaar veel minder opbracht dan mais en dat in 2018 de opbrengsten in beide gevallen veel lager waren dan in 2017, maar dat sorghum daar in relatieve zin minder last van had. In 2018 was de droogte gekomen na een goede start. Uit Figuur 4-2 volgt dat het begin van 2019 droog was. Echter na het inzaaien was er een natte periode. Daarna volgde een lange droge periode. Mei was ook een koude maand en pas na 1 juni bleven de daggemiddelde temperaturen boven de $15^{\circ} \mathrm{C}$. De gewasopbrengsten waren wat lager dan in 2018, vooral voor de sorghum: de gewasopbrengst ten opzichte van 2017 was in 2019 bij snijmais 57\% (11,3 t/ha DS) en bij sorghum C7 59\% (7,5 t/ha DS). Ten opzichte van 2018 was dat dus vooral voor de sorghum een moeilijk jaar. Geconcludeerd kan worden dat in 2017 voor zowel de snijmais als de sorghum de weersomstandigheden goed waren en 2017 een 'groeizaam' jaar was, waarbij de opbrengst van de sorghum wel veel lager was dan van de snijmais. Het begin van 2018 was goed en niet te droog. Daarna kwam een lange droge periode, waarin de sorghum zich kon bewijzen als droogtebestendig gewas met mogelijkheden om diep in een verdichte ondergrond te dringen. Dit bleek voor de sorghum C7 echter maar zeer beperkt het geval (afgaand op de bovengenoemde relatieve opbrengsten) en niet genoeg in vergelijking met de maisopbrengsten. In de jaren 2019 en 2020 was het begin van groeiperiode droog en koud en dat was voor met name de sorghum slecht. Het lijkt erop dat de sorghum deze slechte start niet te boven is gekomen in de rest van de groeiperiode. Dit had ook tot gevolg dat de waterbehoefte duidelijk lager was dan voor de snijmais. 


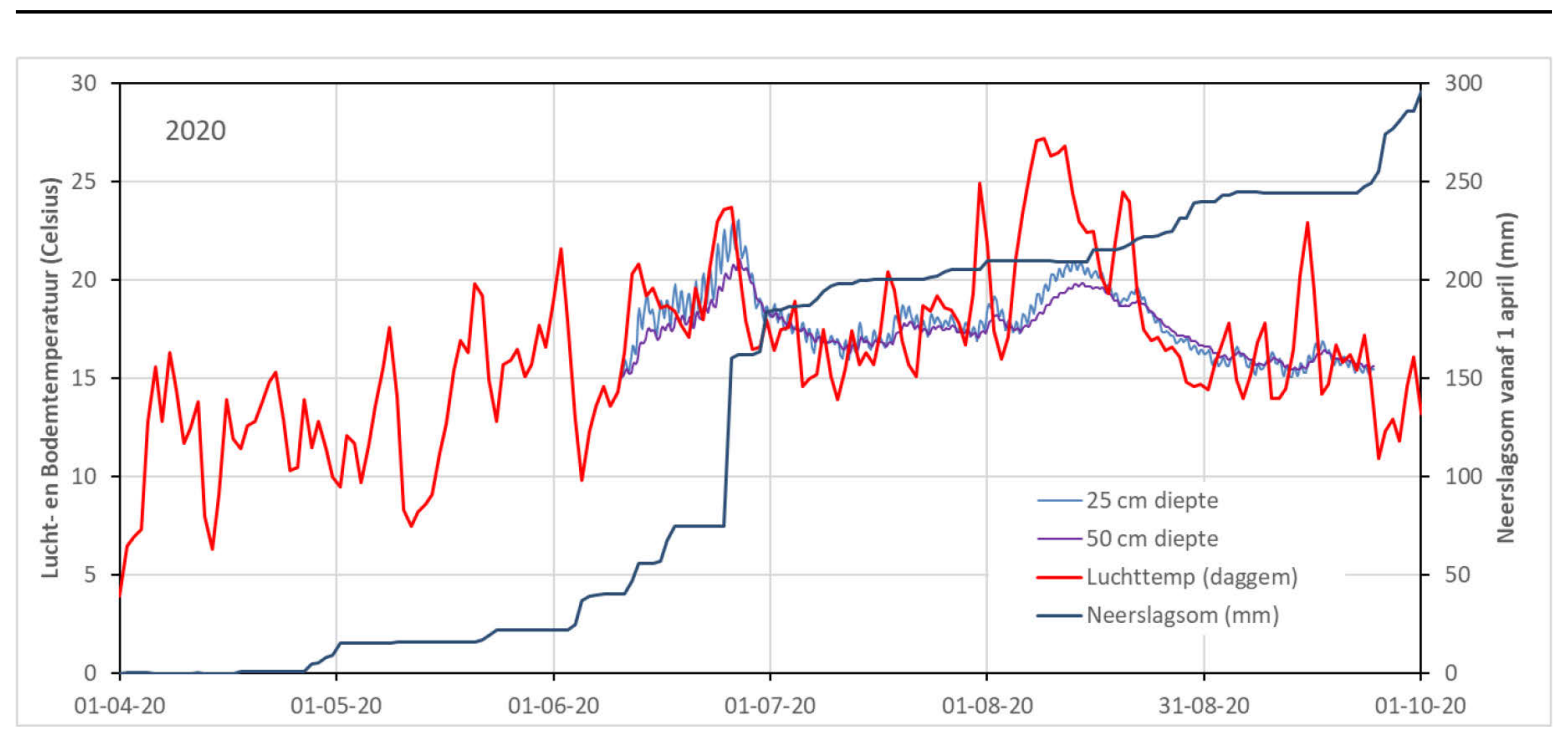

Figuur 4-18 Neerslagsom in mm, bodemtemperatuur op 25 en $50 \mathrm{~cm}$ diepte en gemiddelde dagtemperatuur in ${ }^{\circ} \mathrm{C}$ in 2020.
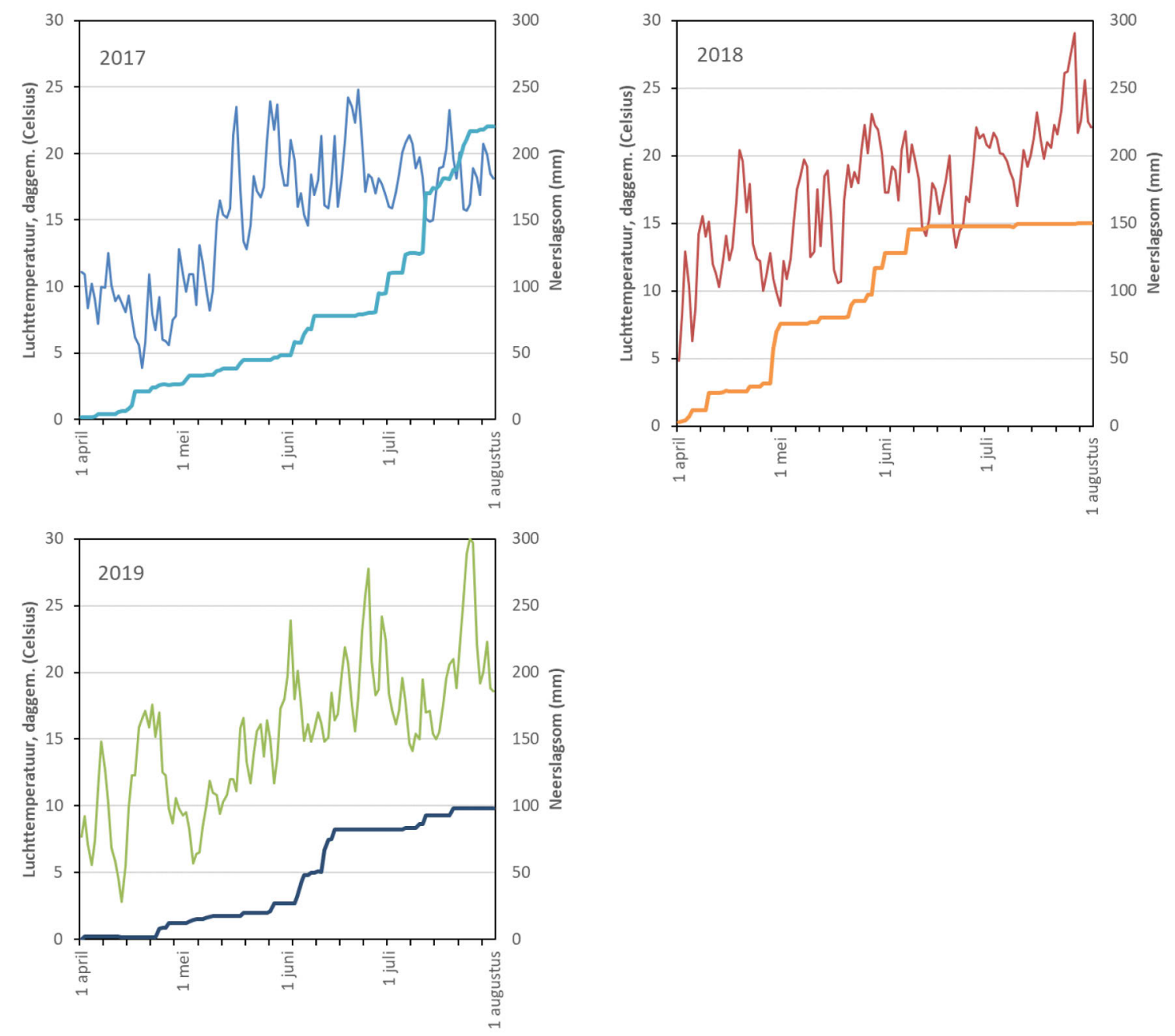

Figuur 4-19 Neerslagsom ( $\mathrm{mm}$ ) en gemiddelde dagtemperatuur in 2017, 2018 en 2019. 
Tabel 4-20 Geschatte waterbeschikbaarheid van de bouwvoor in $\mathrm{mm}$ berekend uit de gewichtsvochtgehaltes in veldje S2 (Tabel 3-7) met een volumegewicht van gemiddeld $1,47 \mathrm{~g} \mathrm{~cm}^{-3}$.

\begin{tabular}{lcccc} 
Periode & $2017(23 \mathrm{mei})$ & 2018 & 2019 & 2020 \\
Voorjaar & 68,4 & 71,0 & 56,1 & 97,8 \\
\hline Najaar & n.d. & 34,5 & 48,4 & 48,9 \\
\hline Verschil & n.d. & 36,5 & 7,7 & 48,9 \\
\hline
\end{tabular}

n.d.: geen data beschikbaar

Uit de waarnemingen blijkt dat de sorghum in de jaren 2018, 2019 en 2020 door een droog voorjaar een slechte kieming had. De foto's in Figuur 3-13 laten dit ook zien voor het jaar 2020. Ook waren de opbrengsten van de sorghum laag. Van de mais was de opbrengst in 2017 met 20 ton droge stof (DS) per hectare goed, maar in de andere jaren matig. Een lage opbrengst gaat samen met een laag watergebruik. Uit de literatuur (Wagner \& Knoblauch, 2011 in Schittenhelm \& Schroetter, 2014) volgt dat van mais per 5,4 gram DS opbrengst het watergebruik $1 \mathrm{~kg}$ is. Van sorghum is dit 5,2 g DS per $\mathrm{kg}$ water. Deze cijfers zijn gebruikt om uit de gemeten drogestofopbrengsten in onze proef een geschat waterverbruik te berekenen. De resultaten zijn vergeleken met de neerslag in het groeiseizoen tot 1 september, omdat na 1 september in alle jaren de neerslag groter was dan de gewasverdamping, die in de periode na 1 september al klein was. De vergelijking is gepresenteerd in Tabel 4-2 (aanvulling op Tabel 3-1). Uit de vergelijking in Tabel 4-2 van de neerslag tot 1 september met het geschatte watergebruik volgt dat de sorghum C7 over het hele seizoen gezien in principe geen watertekort moest hebben gehad: het hogere waterverbruik van de mais laat zien dat dat water beschikbaar was voor opname en groei. De slechte kieming en groei en daardoor een beperkte opbrengst van de sorghum C7 heeft er mogelijk wel voor gezorgd dat de sorghum hoogstens tijdelijk een watertekort heeft gehad, indien die trage begingroei ook de worteldiepte ten opzichte van de mais beperkte. De sorghum Suzy in 2020 had een hogere opbrengst dan de sorghum C7 en daardoor een hoger berekend watergebruik van $182 \mathrm{~mm}$. Dit is echter ook minder dan de neerslag tot 1 september. De snijmais heeft in alle vier jaren wel een deel van de watervoorraad in de bodem moeten gebruiken. Dit zal deels de bodemvochtvoorraad in de bouwvoor zijn aan het begin van het groeiseizoen, maar ook zal er een zekere capillaire opstijging vanuit de ondergrond hebben plaatsgevonden.

Tabel 4-21 Cumulatieve neerslag, Makkink-referentie verdamping en neerslagtekort (alles in mm) gedurende de vier groeiseizoenen (Tabel 3-1), aangevuld met de neerslag tot 1 september en het watergebruik berekend uit de drogestofopbrengst.

\begin{tabular}{|c|c|c|c|c|c|c|c|}
\hline \multirow[b]{2}{*}{ Jaar } & \multirow[b]{2}{*}{ Groeiseizoen } & \multirow[b]{2}{*}{$\begin{array}{l}\text { Neerslag } \\
(\mathrm{mm})\end{array}$} & \multirow{2}{*}{$\begin{array}{l}\text { Makkink ref. } \\
\text { verdamping } \\
(\mathrm{mm})\end{array}$} & \multicolumn{2}{|c|}{ Neerslagoverschot } & \multicolumn{2}{|c|}{ Watergebruik } \\
\hline & & & & $(\mathrm{mm})$ & $\begin{array}{l}\text { Tot } 1 \text { sep } \\
(\mathrm{mm})\end{array}$ & $\begin{array}{l}\text { Snijmais } \\
(\mathrm{mm})\end{array}$ & $\begin{array}{l}\text { Sorghum C7 } \\
(\mathrm{mm})\end{array}$ \\
\hline 2018 & 17 mei - 25 september & 192 & 447 & -256 & 158 & 219 & 154 \\
\hline 2019 & 17 mei - 7 oktober & 223 & 426 & -203 & 136 & 217 & 139 \\
\hline
\end{tabular}

Tegen de proefplot aan, is in 2017 en 2018 in het kader van een promotieonderzoek een onderzoek uitgevoerd naar het effect van het aanbrengen van boorgaten in de ondergrond tot een diepte van $60 \mathrm{~cm}$ (Yang et al., 2021). Deze gaten, met diameters van 6 en $9 \mathrm{~cm}$, werden opgevuld met grond uit de bouwvoor met en zonder mest. Zowel de snijmais als de sorghum C7 maakten gebruik van deze boorgaten om dieper te wortelen. Voor 2017 leverde de diepere beworteling in de boorgaten geen significant grotere korrelopbrengsten en wortelmassa's op voor zowel de snijmais als de sorghum C7. In het droge jaar 2018 was dit wel het geval voor de snijmais, maar niet voor de sorghum. Ook dit is een aanwijzing dat de sorghum door de slechte en late opkomst voldoende had aan het water in de bouwvoor en de neerslag en maar beperkte droogtestress heeft ondervonden. Een grote noodzaak om dieper te wortelen was voor de sorghum (behalve bij de start) niet aanwezig. Anderzijds laat de proef met de boorgaten zien dat indien dieper wortelen dan de bouwvoor mogelijk is, zowel de snijmais als de sorghum daar gebruik van maakt. 
In 2020 zijn de behandelingen aangelegd om een eventueel effect van vruchtwisseling van mais na sorghum te onderzoeken. Meerdere bronnen wijzen erop dat sorghum onkruid kan onderdrukken (Einhellig \& Rasmussen, 1989; Farooq et al., 2020), evenals de ziekte- en plaagdruk kan verlagen (Branson et al., 1969; Djian-Caporalino et al., 2019) voor mais in rotatie met sorghum. Dit zou kunnen leiden tot een verhoogde opbrengst in mais na sorghum. In onze proef waren de drogestof-, zetmeel- en stikstofopbrengsten hoger in de behandeling met vruchtwisseling dan in de behandeling met continuteelt van mais, hoewel niet significant. Dit wijst er ook op dat er onvoldoende bodemverbetering plaatsvond onder sorghum, maar mais in het volgende jaar nog van zou kunnen profiteren. Ook kan dit betekenen dat:

1. De ziekte- en plaagdruk in het proefveld voor mais al laag was en de opbrengst in de continumaisbehandeling niet voldoende beïnvloed heeft om een significant effect van vruchtwisseling te bewerkstelligen. De plotjes met mais werden immers omringd door plotjes met sorghum en op het perceel om het proefveld heen werd in 2020 ook sorghum geteeld.

2. Het onderdrukkende effect van sorghum op onkruid, ziekte en plaaginsecten niet afdoende geweest kan zijn voor de mais om daar nog van de profiteren na vruchtwisseling. Zowel onkruidals ziekte- en plaagdruk zijn in deze proef niet gemeten, waardoor we hier geen concluderende uitspraak over kunnen doen.

Om verschillende redenen is het lastig om de resultaten van het Duitse onderzoek (Schittenhelm \& Schroetter, 2014) te vergelijken met de hier behaalde bevindingen. Verschillen in rassen, watervoorziening, grondsoort en mogelijk in indringingsweerstanden zijn hier debet aan. Ook waren de proefvelden bij Schittenhelm \& Schroetter overkapt met doorzichtig plastic om de watervoorziening te reguleren. Dit zal ook hogere bodemtemperaturen tot gevolg hebben. Doordat in onze proef de beworteling niet tot in de verdichte laag is gedrongen, hebben we ook geen veranderingen in de eigenschappen van die laag kunnen waarnemen. Overigens verwachten we niet dat een kleine hoeveelheid wortels in de verdichte laag zal leiden tot substantiële veranderingen in droge bulkdichtheid. Indien een voorgewas wel tot in de verdichte laag kan doordringen, zouden de wortels van volggewassen de oude wortelgangen kunnen gebruiken en zo dieper wortelen. Dit hebben we echter niet kunnen waarnemen in deze proef.

De verschillen in nitraatresidu (NR; N-mineraal in najaar) tussen de behandelingen zouden het gevolg kunnen zijn van verschillen in stikstofbodembalans. Aangezien de hoeveelheden $\mathrm{N}$-mineraal in het voorjaar en de hoeveelheid bemesting niet verschillend waren tussen de behandelingen, kan dit worden nagegaan met het verband tussen NR met de N-opbrengst door het gewas (zie Tabel 3-8 t/m Tabel 3-11). Ook zonder de twee uitbijters in 2019 (M1 en S2) lijkt er geen verband van NR met $\mathrm{N}$-opbrengst (en dus $\mathrm{N}$-bodembalans) te zijn geweest (Figuur 4-3).

Deze proef geeft geen duidelijke aanwijzingen voor een verschil in nitraatuitspoelingsrisico tussen de twee gewassen, maar hiervoor gelden dezelfde nuanceringen als hierboven rondom het thema waterbenutting. Het is zeker niet uitgesloten dat met een andere raskeuze, bij een droogtegevoeliger maar beter bewortelbaar bodemtype én gunstigere startomstandigheden voor de sorghum, wel verschillen in bewortelingsintensiteit en -diepte tot uitdrukking komen tussen sorghum en mais en daarmee ook een verschil in het risico op nitraatuitspoeling. 


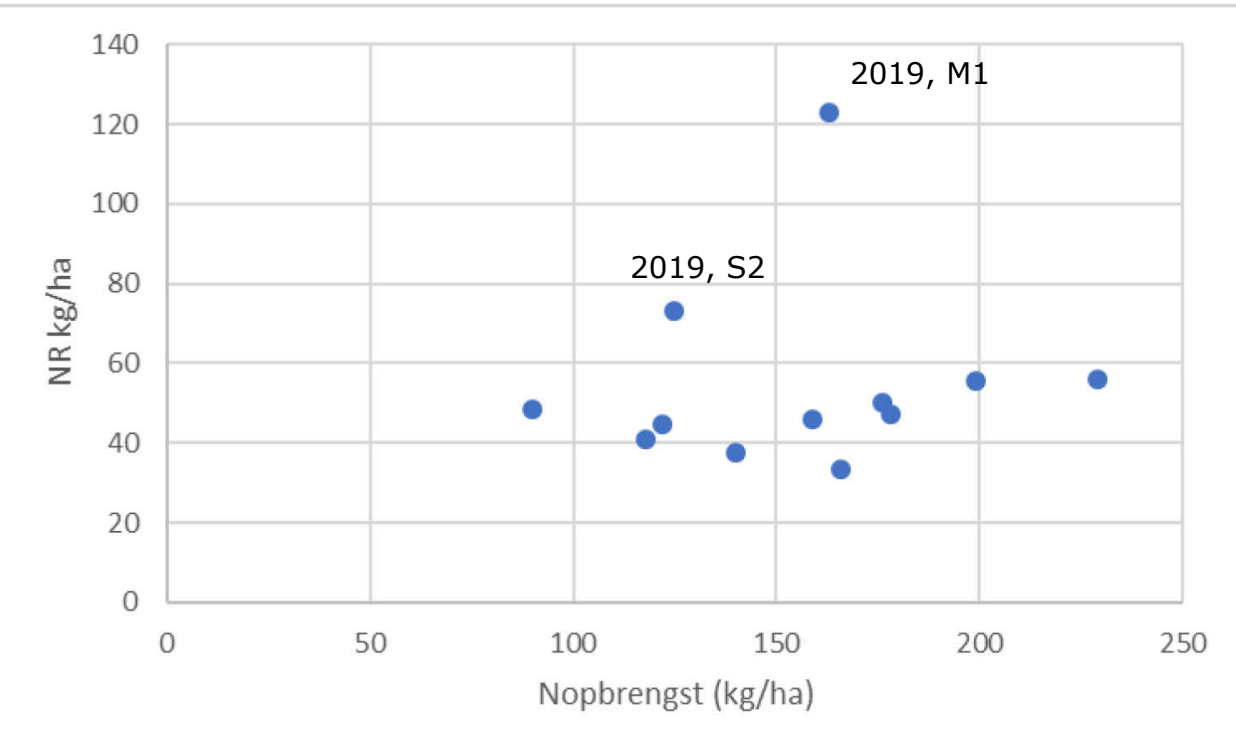

Figuur 4-20 Relatie tussen N-opbrengst en nitraat-residu (NR) voor alle behandelingen en jaren.

\subsection{Conclusies}

Enkele puntsgewijze conclusies zijn als volgt.

- Het proefveld had zoals bedoeld een uitgesproken verdichte ondergrond die voor de meeste gewassen zoals snijmais niet bewortelbaar is. Deze zandgrond was minder droogtegevoelig dan bedoeld, maar daar staat tegenover dat vooral 2018, maar ook 2019 en 2020 droge jaren waren. Beworteling van de ondergrond zou naar verwachting in deze jaren een grotere beschikbaarheid van water en daardoor een hogere opbrengst opleveren.

- Zoals verwacht, is de beworteling van snijmais beperkt gebleven tot de bouwvoor. Beworteling van de ondergrond was door de hoge indringingsweerstand onmogelijk.

- Van de onderzochte sorghumrassen C7, Piper (2017) en Suzy (2020), had alleen Piper een wat diepere beworteling (tot circa $47 \mathrm{~cm}$ ) bij een bouwvoor van circa 35 tot maximaal $40 \mathrm{~cm}$ diepte. Sorghum Piper is een structuurgewas met een zeer laag zetmeelgehalte en daarom voor melkveehouders minder interessant als aanvulling op veevoer.

- De start en ontwikkeling van de sorghum waren door de een combinatie van koude en droge voorjaren slechter dan mais. Dit bleek uit een trage en lage opkomst die later wel wat bijtrok. Deze groeiachterstand zal een belangrijke oorzaak zijn van de lage opbrengsten van sorghum. Verdere veredeling van sorghum op koudetolerantie/startontwikkeling (zoals bij mais bij de introductie in NW-Europa is gebeurd) zal zeker bijdragen aan betere prestaties van dit gewas.

- De trage en beperkte gewasgroei beperkte ook het watergebruik tot ongeveer de hoeveelheid neerslag die in de groeiperiode tot 1 september is gevallen. De sorghum zal, behalve bij de startontwikkeling die cruciaal is geweest voor de verdere groei, daarom niet veel droogtestress hebben ondervonden. Dit was wel het geval voor de snijmais en zal deels de verklaring zijn dat in 2017 de opbrengst goed was en in de drogere jaren 2018, 2019 en 2020 de opbrengsten matig waren.

- In het droge jaar 2018 waren de omstandigheden zodanig dat beworteling van de ondergrond door de sorghum werd verwacht. Dit bleek niet het geval en waarschijnlijk is sorghum C7 niet in staat om in de verdichte ondergrond te dringen.

- $\mathrm{Er}$ is geen duidelijk verschil gevonden in het uitspoelingsrisico van nitraat tussen beide gewassen. Alleen in het proefjaar 2019 was dit risico voor mais significant hoger. 


\subsection{Aanbevelingen}

Het uitgevoerde onderzoek was opgestart met verwachtingen gebaseerd op positieve ervaringen zoals gerapporteerd in buitenlands onderzoek. Sorghum is van origine een tropisch gewas en er was/is onder Nederlandse omstandigheden nog weinig of geen ervaring mee. Het ligt voor de hand om nog steeds aandacht te blijven besteden aan veredeling van sorghum, zodat het ook onder Nederlandse omstandigheden bij zowel een koud als relatief warm voorjaar en onder droge en soms natte omstandigheden goed kan groeien en tevens een goed en diep wortelstelsel ontwikkelt in een dichte ondergrond. Uiteraard moeten dit tevens rassen zijn die na de oogst ook nuttig gebruikt kunnen worden, bijvoorbeeld als veevoer. In het proefveld bleek dat het grondwater relatief ondiep was. Het ligt voor de hand om een dergelijke proef te herhalen met meerdere sorghumrassen met een potentieel voor een diepe beworteling op een zandgrond waar vaststaat dat het grondwater veel dieper zit, en mogelijk ook een zandgrond met een iets minder dikke A-horizont. In deze proef was er bewust voor gekozen om bij droogte niet te snel in te grijpen met beregenen. In een eventuele vervolgproef zou bij droogte vroeg in het seizoen juist wel beregend moeten worden om het gewas een goede beginontwikkeling te geven. 


\section{Literatuur}

Bhatt, R.K. 1995. Light Interception, Leaf Area Index and Dry Matter Yield in Fodder Sorghum at Different Plant Populations. Journal of Agronomy \& Crop Science 174, 287-290

Branson, T.F., P.L. Guss \& E.E. Ortman. 1969. Toxicity of sorghum roots to larvae of the western corn rootworm. Journal of Economic Entomology, 62(6), 1375-1378.

De Wit, J., N.J.M. van Eekeren. 2015. Sorghum in Nederland. Resultaten van diverse experimenten in 2015. 2015-055 LbD. Louis Bolk Instituut, Driebergen.

Deru, J.G.C., S. van de Goor, N.J.M. van Eekeren, A. de Vliegher, J. Pannecoucque, J. van Waes. 2018. Sorghum als derde gewas in de melkveehouderij: Proeven met rassen, zaaidichtheid en bemesting in Nederland en Vlaanderen. 2018; 010 LbD. Louis Bolk Instituut i.s.m. ILVO, Bunnik.

Djian-Caporalino, C., T. Mateille, M. Bailly-Bechet, N. Marteu, A. Fazari, P. Bautheac, A. Raptopoulo, L. van Duong, J. Tavoillot, B. Martiny, C. Goillon \& P. Castagnone-Sereno. 2019. Evaluating sorghums as green manure against root-knot nematodes. Crop Protection, 122, 142-150.

Einhellig, F.A., \& J.A. Rasmussen. 1989. Prior cropping with grain sorghum inhibits weeds. Journal of Chemical Ecology, 15(3), 951-960.

Farooq, M., I., Khan, A. Nawaz, M.A. Cheema \& K.H. Siddique. 2020. Using sorghum to suppress weeds in autumn planted maize. Crop Protection, 133, 105162.

Farré, I. \& J.M. Faci. 2006. Comparative response of maize (Zea mays L.) and sorghum (Sorghum bicolor L. Moench) to deficit irrigation in a Mediterranean environment. Agricultural Water Management, 83(1-2), 135-143.

Genstat. 2018. Genstat 64-bit Release 19.1 (PC/Windows 8). (c) VSN International Ltd.

Nguy-Robertson, A., A. Gitelson, Y. Peng, A. Viña, T. Arkebauer, and D. Rundquist. 2012. Green Leaf Area Index Estimation in Maize and Soybean: Combining Vegetation Indices to Achieve Maximal Sensitivity. Agronomy Journal 104:1336-1347, doi:10.2134/agronj2012.0065

Schittenhelm, S. \& S. Schroetter. 2014. Comparison of drought tolerance of maize, sweet sorghum and sorghum-sudangrass hybrids. Journal of Agronomy and Crop Science, 200(1), 46-53.

Schittenhelm, S. 2010. Effect of Drought Stress on Yield and Quality of Maize/Sunflower and Maize/Sorghum Intercrops for Biogas Production. Journal of Agronomy \& Crop Science, 196 pp 253-261. doi:10.1111/j.1439-037X.2010.00418.x

Steduto, P., N. Katerji, H. Puertos-Molina, M. Mastrorilli \& G. Rana. 1997. Water-use efficiency of sweet sorghum under water stress conditions Gas-exchange investigations at leaf and canopy scales. Field Crops Research, 54(2-3), 221-234.

Van Agtmaal, M., J. de Wit \& N.J.M. van Eekeren. 2020. Stikstofbenutting van sorghum: Resultaten van 2 jaar bemestingsproeven. 2020-014 LbD. Louis Bolk Instituut, Bunnik.

Van Agtmaal, M., J.G.C. Deru, J. Pannecoucque \& N.J.M. van Eekeren. 2019. Sorghum als aanvullend ruwvoergewas: Proeven met bemesting en rassen in Nederland en Vlaanderen. 2019-009 LbD. Louis Bolk Instituut, Bunnik.

Van de Goor, S., N.J.M. van Eekeren, A. de Vliegher, J. Pannecoucque, B. Vandecasteele \& J. van Waes. 2017. Sorghum als derde gewas in de melkveehouderij: Perspectieven van rassen en gewasrotatie in beeld. 2017-006 LbD. Louis Bolk Instituut, Driebergen.

Van den Akker, J.J.H. \& T. Hoogland. 2011. Comparison of risk assessment methods to determine the subsoil compaction risk of agricultural soils in The Netherlands. Soil \& Tillage Research 114, 146-154.

Van den Akker, J.J.H. 2008. Soil compaction. In: Huber, S., Prokop, G., Arrouays, D., Banko, G., Bispo, A., Jones, R.J.A., Kibblewhite, M.G., Lexer,W., Moller, A., Rickson, R.J., Shishkov, T., Stephens, M., Toth, G. Van den Akker, J.J.H., Varallyay, G., Verheijen, F.G.A., Jones, A.R. (Eds.) Environmental Assessment of Soil for Monitoring: Volume I Indicators \& Criteria. EUR 23490 EN/1, Office for the Official Publications of the European Communities, Luxembourg, pp 107-124. https://hal.inrae.fr/hal-02822804/document

Van Eekeren, N.J.M., J.G.C. Deru \& S. Gerdes. 2015. Bufferboeren: Productieve maatregelen voor meer droogtetolerantie. 2015-028 LbD. Louis Bolk Instituut, Driebergen. 40 p. 
Van Genuchten, M.Th. 1980. A closed-form equation for predicting the hydraulic conductivity of unsaturated soils. Soil Science Society of America Journal 44: 892-898.

Wright, G.C., R.C.G. Smith \& J.R. McWilliam. 1983. Differences between two grain sorghum genotypes in adaptation to drought stress. I. Crop growth and yield responses. Australian Journal of Agricultural Research, 34(6), 615-626.

Yang, P., W. Dong, J.J.H. van den Akker \& O. Oenema. 2021. Corings significantly relieve soil compaction and increase yield, field experiments. (in voorbereiding)

Zegada-Lizarazu, W., A. Zatta, \& A. Monti. 2012. Water uptake efficiency and above-and belowground biomass development of sweet sorghum and maize under different water regimes. Plant and Soil, 351(1), 47-60. 


\section{Bijlage 1 Bodemanalyse proefveld maart 2017}

\begin{tabular}{|c|c|c|c|c|c|c|c|c|c|}
\hline Onderzoek & $\begin{array}{l}\text { Onderzoek-/ordernr: } \\
742742 / 004031500\end{array}$ & $\begin{array}{l}\text { Datum monstername: } \\
07-03-2017\end{array}$ & $\begin{array}{l}\text { Datum verslag: } \\
\text { 17-03-2017 }\end{array}$ & & $\begin{array}{l}\text { Kopiehouder: } \\
\text { Agrifirm Exlan } \\
\text { Postbus } 1033\end{array}$ & $\begin{array}{l}\text { Froklag } \\
40 \mathrm{KA}\end{array}$ & $\begin{array}{l}\text { I M.Stap } \\
\text { MEPPEL }\end{array}$ & & \\
\hline \multirow{6}{*}{$\begin{array}{l}\text { Resultaat } \\
\text { hoofdelement }\end{array}$} & & Eenheid & Resultaat & Gem.* & Streeftraject & laag & vrij laag & goed & vrij hoog hoog \\
\hline & $\begin{array}{l}\mathrm{N} \text {-totale bodemvoorraad } \\
\mathrm{C} / \mathrm{N} \text {-ratio } \\
\mathrm{N} \text {-leverend vermogen }\end{array}$ & $\begin{array}{l}\mathrm{mg} \mathrm{N} / \mathrm{kg} \\
\mathrm{kg} \mathrm{N} / \mathrm{ha}\end{array}$ & $\begin{array}{l}830 \\
19 \\
28\end{array}$ & $\begin{array}{l}16 \\
54\end{array}$ & $\begin{array}{l}13-17 \\
93-147\end{array}$ & & & & \\
\hline & $\begin{array}{l}\text { S-totale bodemvoorraad } \\
\text { C/S-ratio } \\
\text { S-leverend vermogen }\end{array}$ & $\begin{array}{l}\mathrm{mg} \mathrm{S} / \mathrm{kg} \\
\mathrm{kg} \mathrm{S} / \mathrm{ha}\end{array}$ & $\begin{array}{l}190 \\
82 \\
8\end{array}$ & 11 & $\begin{array}{l}50-75 \\
20-30\end{array}$ & & & & \\
\hline & $\begin{array}{l}\text { P plant beschikbaar } \\
\text { P-bodemvoorraad (P-Al) } \\
\text { Pw }\end{array}$ & $\begin{array}{l}\mathrm{mg} \mathrm{P} / \mathrm{kg} \\
\mathrm{mg} \mathrm{P} \mathrm{O}_{5} / 100 \mathrm{~g} \\
\mathrm{mg} \mathrm{P}_{2} \mathrm{O}_{5} / \mathrm{l}\end{array}$ & $\begin{array}{l}10,4 \\
66 \\
101\end{array}$ & $\begin{array}{l}6,4 \\
72\end{array}$ & $\begin{array}{l}1,3-2,6 \\
30-46\end{array}$ & & & & \\
\hline & $\begin{array}{l}\text { K plant beschikbaar } \\
\text { K-bodemvoorraad }\end{array}$ & $\begin{array}{l}\mathrm{mg} \mathrm{K} / \mathrm{kg} \\
\mathrm{mmol}+/ \mathrm{kg}\end{array}$ & $\begin{array}{l}35 \\
0,8\end{array}$ & & $\begin{array}{l}70-110 \\
2,4-3,5\end{array}$ & & & & \\
\hline & Mg plant beschikbaar & $\mathrm{mg} \mathrm{Mg} / \mathrm{kg}$ & 38 & 76 & $50-85$ & & ש & & \\
\hline \multirow{3}{*}{ fysisch } & Zuurgraad $(\mathrm{pH})$ & & 4,5 & 5,3 & $5,6-6,1$ & 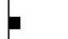 & & & \\
\hline & Organische stof & $\%$ & 2,7 & 3,0 & & & & & \\
\hline & Klei & $\%$ & $<1$ & & & & & & \\
\hline
\end{tabular}

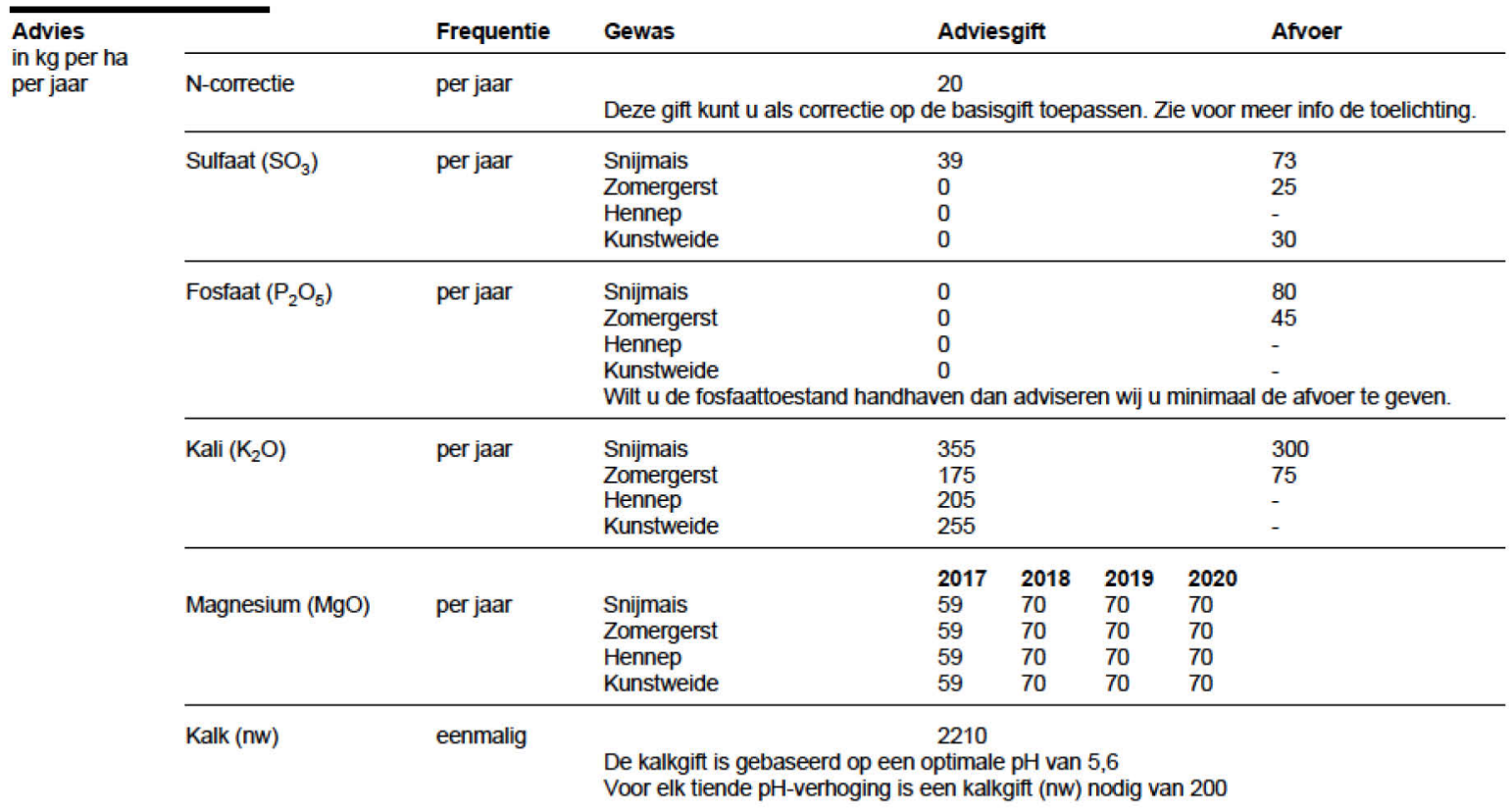




\title{
Bijlage 2 Verkennende proef afbraak van wortels en stoppels van mais en sorghum
}

\author{
Corresponderende auteurs: \\ Joost Sleiderink, Joachim Deru, Maaike van Agtmaal, Nick van Eekeren (Louis Bolk Instituut)
}

\section{Inleiding}

In dit rapport zijn wortel-massametingen beschreven voor sorghum en mais, die een beeld geven van de aanvoer van organische stof in de bodem bij deze gewassen. In het kader van de ontwikkeling van maatregelen in de landbouw voor het verhogen van de bodem-organische stof is het niet alleen van belang de aanvoer van organische stof naar de bodem, maar ook de afbraak van die organische stof te kennen. Door de aanwezigheid van blauwzuur in sorghum zou de afbraak van gewasresten trager kunnen verlopen dan bij mais. Daarnaast kan ook een bodemeffect optreden waarbij eenzelfde type organische stof in een sorghumbodem anders afbreekt dan in een maisbodem.

Vanuit de PPS Sorghum is in 2020 een verkennende afbraakproef uitgevoerd in het sorghum-proefveld in Odiliapeel, met de volgende vragen:

1. Breken de wortels en stoppels van sorghum anders af dan die van mais wanneer deze in hun 'eigen' bodem verteren?

2. Is er een bodemeffect meetbaar op de afbraak van sorghum- en maiswortels en -stoppels in percelen met verschillende voorvruchten (drie jaar sorghum versus drie jaar mais)?

\section{Materiaal en methode}

\section{Strooiselzakjes}

Op 10 juli 2020 werden in het proefveld te Odiliapeel in de behandelingen continu mais en continu C7 wortelpruiken en stoppels geoogst. De wortelpruiken werden voorzichtig met behulp van een spitvork losgemaakt van de bodem om zo veel mogelijk van de fijne wortels te behouden. De wortelpruiken en stoppels zijn vervolgens gewassen, van elkaar gescheiden, in stukken van $1-3 \mathrm{~cm}$ geknipt en gedroogd bij $70{ }^{\circ} \mathrm{C}$ gedurende 24 uur. Houtige delen van de stoppels werden in kleinere stukken van ongeveer $5 \mathrm{~mm}$ geknipt. Stoppels werden in drie delen opgedeeld, namelijk groen materiaal, gelignificeerde stengeldelen en wortelkroon, zodat de originele verhouding van deze drie delen in de strooiselzakjes bewaard konden blijven.

Strooiselzakjes van $5 \times 5 \mathrm{~cm}$ polyurethaan met een maaswijdte van $100 \mu \mathrm{m}$ werden gelabeld, gewogen en vervolgens gevuld met $0,8 \mathrm{~g}$ van de vier gedroogde materialen (maiswortel, maisstoppel, sorghumwortel, sorghumstoppel) en werden vervolgens geseald met een hitte-sealer. In totaal werden er zo 192 strooiselzakjes gemaakt en gevuld, zodat er per plot en per materiaal drie herhalingen waren en twee uitgraafmomenten waarop de helft van de zakjes uitgegraven konden worden.

Op 6 augustus 2020 werden de zakjes in de continu mais en continu C7 plots aan twee kanten van een veldpunaise (vanwege twee uitgraafmomenten) in het midden van een van de middelste rijen ingegraven op een diepte van $8 \mathrm{~cm}$ met een spade, waarbij de bovengrond minimaal werd verstoord. In zowel de mais- als de C7-plots werd dus organisch materiaal van zowel mais als C7 ingegraven.

De eerste batch van 96 strooiselzakjes werd op 18 september 2020 uitgegraven, de tweede batch op 16 oktober 2020. De zakjes werden vrijgemaakt van zand, gedroogd op $70{ }^{\circ} \mathrm{C}$ gedurende 24 uur en gewogen. Het gewicht van het label en zakje werd van het totaalgewicht na uitgraven afgetrokken om zo het gewicht van het resterende organisch materiaal te verkrijgen. Het percentage afgebroken organisch materiaal werd vervolgens berekend door het verschil in gewicht van het organisch materiaal vóór en na ingraven te delen door het gewicht vóór het ingraven. 
$\mathrm{Na}$ afloop werd er voor de twee uitgraafmomenten apart een split-plot ANOVA uitgevoerd in R, waarbij de vier blokken in NZ-richting als blok, plots als heel plot en de vier ingegraven materialen als splitplot behandeld werden.

Theezakjes-index

Naast de strooiselzakjes, werden er op 18 juni 2020 in dezelfde behandelingen (continu mais en continu C7) ook theezakjes ingegraven en uitgegraven op 16 oktober 2020 om de Tea bag-index mee te bepalen. Hierbij werd het protocol gevolgd zoals beschreven door Tea Time 4 Science (http://www.teatime4science.org/wp-content/uploads/scientific.pdf). Het dataformulier voor nietgeweven theezakjes werd gebruikt, omdat de theezakjes die ingezet waren van de niet geweven variant waren. Op de berekende variabelen ( $S$ en $k$ ) werd vervolgens een ANOVA uitgevoerd in $R$ om te testen voor behandelingseffect.

\section{Resultaten}

\section{Strooiselzakjes}

De proef met strooiselzakjes leverde geen significant effect op voor de factor gewas (waar de zakjes onder ingegraven werden) voor beide uitgraafmomenten. Wel werd er een trend $(P=0,09)$ waargenomen voor het uitgraafmoment in september (na 1,5 maand), waarbij het afgebroken percentage van de vier materialen in de maisbehandeling ongeveer 2,5\% lager lag dan in de C7behandeling. Ook werden er significante effecten van materiaal (maiswortel, maisstoppel, sorghumwortel, sorghumstoppel) op het afgebroken percentage gevonden (Tabel B1). Er werden geen significante interactie-effecten waargenomen, wat erop wijst dat de gewasresten niet anders onder eigen gewas afbreken dan onder het andere gewas.

Na 1,5 maand was de afbraak van sorghumwortels significant lager (minder massaverlies) dan van de andere materialen (Figuur B1). Na 2,5 maand was het massaverlies van het sorghummateriaal (zowel stoppel als wortels) relatief gestegen ten opzichte van het maismateriaal, waardoor de sorghumstoppels het hoogste afbraakpercentage (meeste massaverlies) hadden en de sorghumwortels niet meer verschilden van beide maismaterialen.

Tabel B2-1 Split-plot ANOVA resultaten voor A) uitgraafmoment 1 in september 2020 en B) uitgraafmoment 2 in oktober 2020.

\begin{tabular}{|c|c|c|c|c|c|c|}
\hline & \multicolumn{3}{|l|}{$\mathbf{A}$} & \multicolumn{3}{|l|}{ B } \\
\hline Blok (NZ) & 3 & 0,02 & 0,99 & 3 & 1,37 & 0,40 \\
\hline Materiaal & 3 & 8,96 & $<0,001$ & 3 & 8,04 & 0,001 \\
\hline Behandeling*materiaal & 3 & 1,27 & 0,31 & 3 & 0,94 & 0,44 \\
\hline
\end{tabular}




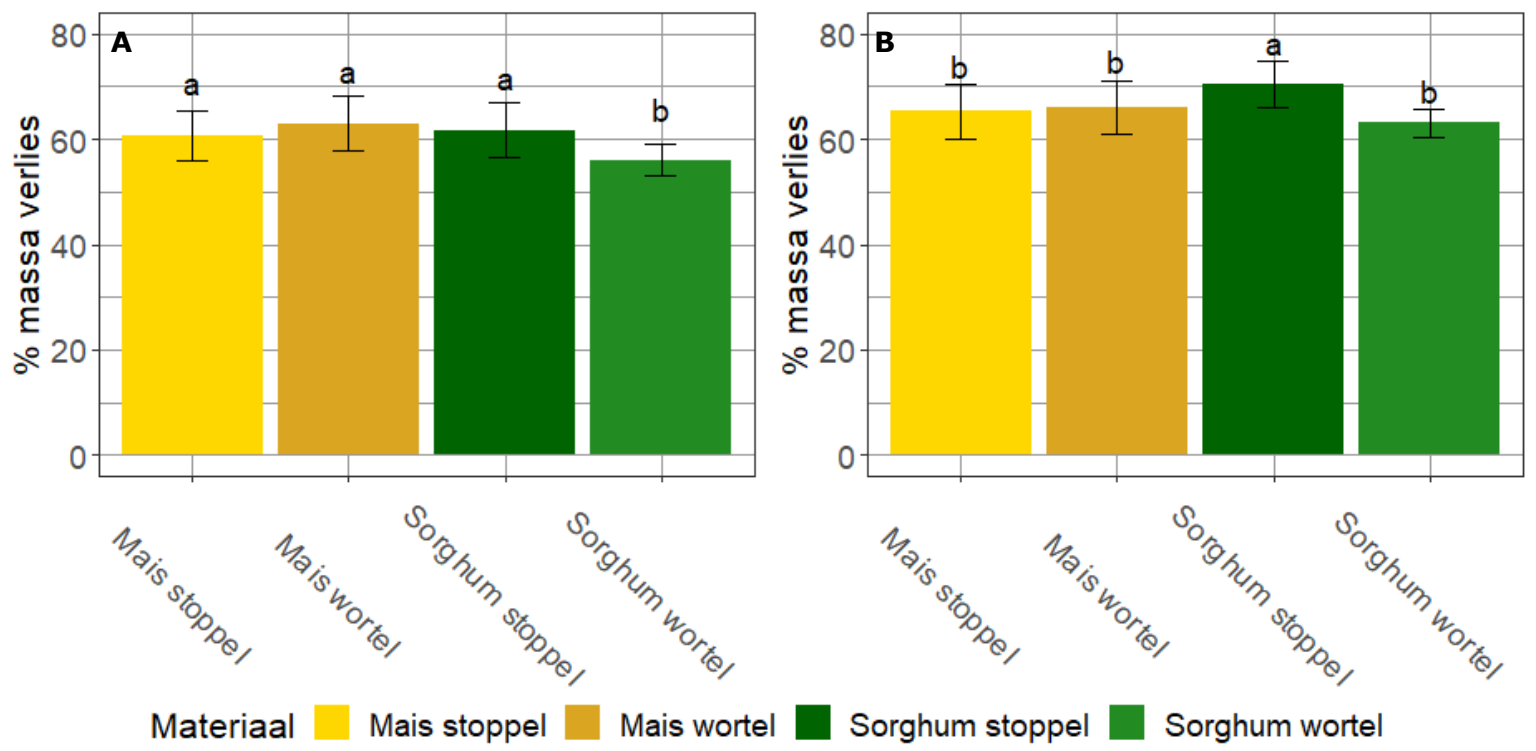

Figuur B1-1 Het gemiddelde percentage afgebroken organisch materiaal per materiaaltype voor A) uitgraafmoment 1 in september 2020 en B) uitgraafmoment 2 in oktober 2020. Foutbalken geven standaarddeviatie weer.

\section{Theezakjes-index}

De theezakjes-indexmethode bepaalt twee variabelen, namelijk de decompositiesnelheid (k) en de strooisel-stabilisatiefactor (S). De stabilisatiefactor (S) geeft een waarde voor de afbraak van de moeilijk afbreekbare verbindingen (bijvoorbeeld lignine). Hoe hoger $S$, hoe meer moeilijk afbreekbare organische stof achterblijft in de bodem (Keuskamp et al., 2013). Er werden geen verschillen waargenomen in de decompositiesnelheid $(k)$ tussen de bodems onder mais of sorghum. De stabilisatiefactor (S) toonde echter wel een significant verschil, wat laat zien dat in de bodem onder continue maisteelt de afbraak van moeilijker afbreekbare organische stof lager is en er meer organische stof in de bodem achterblijft dan in de sorghumbodem.
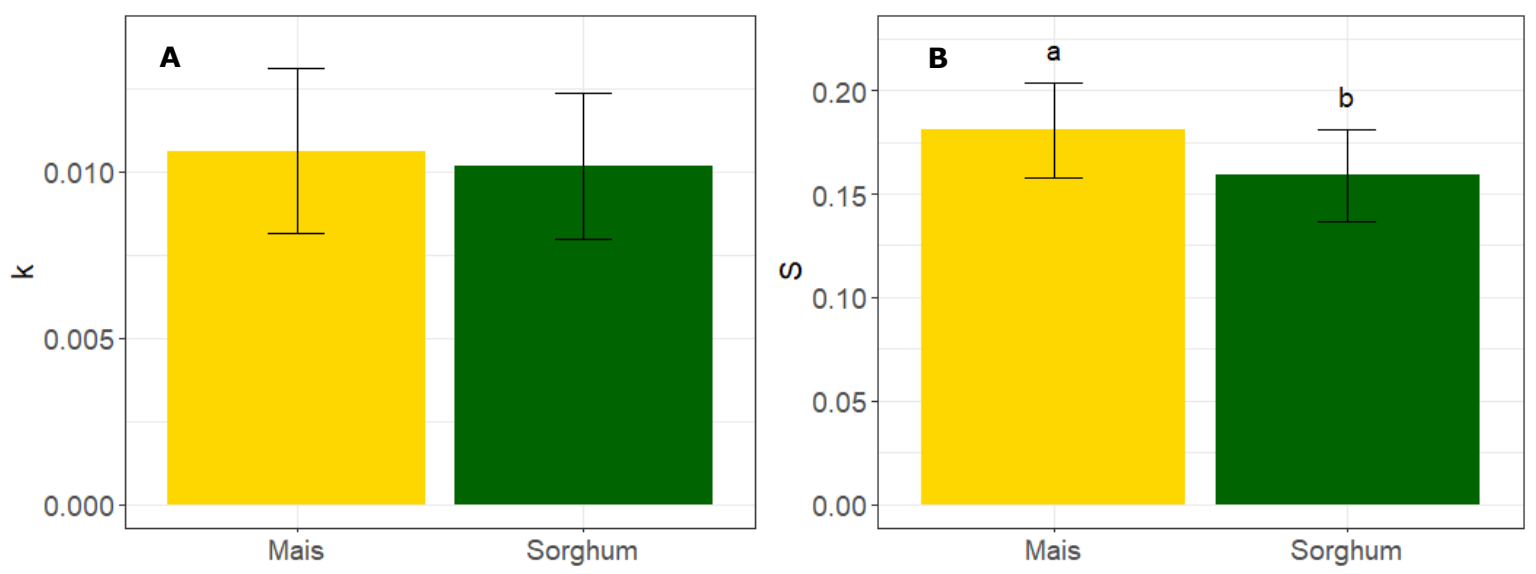

Figuur B2-2 De gemiddelde waardes per gewas voor A) de decompositiesnelheid $k$ en B) de stabilisatiefactor S. Foutbalken geven standaarddeviatie weer.

\section{Discussie en conclusies}

De gelijkwaardige gemiddelde afbraak van gewasresten onder sorghum of mais is een indicatie dat er geen verschil in koolstofvastlegging via deze route is tussen deze twee gewassen. Ook kunnen we op basis van de afwezigheid van een interactie-effect concluderen dat de ingegraven gewasresten van mais of sorghum niet sneller afbreken onder het groeiende gewas van eigen soort in vergelijking met de andere soort. De gelijkwaardige afbraaksnelheid berekend met de theezakjes-index benadrukt dat er geen verschil is in de bodem van mais en sorghum. Echter werd er wel een verschil in de 
stabilisatiefactor (S) gevonden, waardoor onder mais meer stabilisatie van organische stof in de bodem plaatsvindt dan onder sorghum (Keuskamp et al., 2013), wat wellicht op de lange termijn invloed zou kunnen hebben op koolstofvastlegging. Koolstofvastlegging hangt echter af van een veelvoud aan andere variabelen die zouden kunnen verschillen tussen sorghum en mais, zoals $\mathrm{C}$-input, C/N-ratio's van gewasresten of bewortelingsdiepte.

Desalniettemin blijkt er na 2,5 maand gemiddeld minder sorghumstoppel over te blijven dan de overige getoetste gewasresten, wat in lijn is met de lagere stabilisatiefactor (S) onder sorghum dan onder mais. Dit zou kunnen leiden tot verschillen in koolstofvastlegging op de lange termijn. Maar mogelijk zou de hogere afbraak van de sorghumstoppels ook aan de afrijping van het gewas kunnen liggen. De stoppels en wortels waren in een vroeg groeistadium bemonsterd (18 juni) en de sorghum was ten tijde van bemonstering aanzienlijk kleiner, met een minder ontwikkeld wortelstelsel met wortels die daarom waarschijnlijk nog minder gelignificeerd waren. Dit zou de afbraak beïnvloed kunnen hebben.

Het is bekend dat sorghum als stressrespons blauwzuur (waterstofcyanide) kan vormen, net als veel andere planten, maar dat mais dit niet kan. Deze toxische stof, die kan beschermen tegen vraat, ziektes en een rol kan spelen bij stresstolerantie, komt zowel in scheut als wortel voor (Ikediobi et al., 1988; Starr et al., 1984). Daarnaast scheidt sorghum een andere toxische stof af: sorgoleon. Deze stof kan een onderdrukkend effect hebben op organismen in de rhizosfeer (Weston et al., 2013). We hadden daarom verwacht dat de afbraak van sorghum-gewasresten langzamer zou verlopen, met name in de plotjes met mais waar het bodemleven niet door deze stoffen beïnvloed zou zijn. De afwezigheid van een interactie-effect van materiaal en behandeling (C7 of mais) wijst echter op de afwezigheid van dit zogenaamde home-field effect. Daarnaast blijkt dat de afbraak, ondanks een zeer droge bodem en weinig neerslag gedurende de eerste 1,5 maand na ingraven, hoog is geweest, gemiddeld was zo'n 60 procent van het organisch materiaal na 1,5 maand al afgebroken. In de daaropvolgende maand volgde er slechts een afbraak van nog $6 \%$ gemiddeld, hoewel er in die maand meer neerslag viel dan in de eerste 1,5 maand. Dit is mogelijk te verklaren door het feit dat de gewasresten opnieuw jong, groen, niet veel gelignificeerd en daarom makkelijk afbreekbaar waren. Het labiele materiaal zou in de eerste 1,5 maand snel afgebroken kunnen zijn geweest, waarna moeilijker te verteren materiaal overbleef.

\section{Referenties}

Ikediobi, C. O., Olugboji, O., \& Okoh, P. N. (1988). Cyanide profile of component parts of sorghum (Sorghum bicolor L. Moench) sprouts. Food chemistry, 27(3), 167-175

Keuskamp, J. A., Dingemans, B. J., Lehtinen, T., Sarneel, J. M., \& Hefting, M. M. (2013). Tea Bag Index: a novel approach to collect uniform decomposition data across ecosystems. Methods in Ecology and Evolution, 4(11), 1070-1075.

Starr, J. L., Newton, R. J., \& Miller, F. R. (1984). Presence of Dhurrin in Sorghum Root Tissue and the Effect of Pathogenesis on Hydrogen Cyanide Potential 1. Crop science, 24(4), 739-742.

Weston, L. A., Alsaadawi, I. S., \& Baerson, S. R. (2013). Sorghum allelopathy-from ecosystem to molecule. Journal of Chemical Ecology, 39(2), 142-153. 


\section{Bijlage 3 Waterretentie- en doorlatendheidskarakteristieken}

In de hoofdtekst zijn de waterretentiecurve en de doorlatendheid bij verzadiging gegeven. Naast deze metingen zijn ook de retentie- en doorlatendheidskarakteristieken bepaald met behulp van de verdampingsmethode. Deze zijn uitgevoerd conform de vereisten voor BIS-Nederland en BRO (Bakker et al., 2020; monsteridentificatienummers MIN 10156 - 10161). In Tabel B3-1 zijn voor alle monsters de textuur en droge bulkdichtheid gegeven, in Tabel B3-2 zijn de Mualem-Van Genuchten-parameters gegeven, alsook de gemeten doorlatendheid bij verzadiging, en in Figuur B3-1 zijn de curven grafische weergegeven.

Tabel B3-1 Gegevens over de textuurverdeling, het organische stofgehalte en de droge bulkdichtheid voor de duplo monsters van de drie bemonsterde lagen (Bakker et al., 2020).

\begin{tabular}{llllllll} 
MIN & $\begin{array}{l}\text { Diepte } \\
(\mathrm{cm}-\mathrm{mv})\end{array}$ & $\begin{array}{l}\text { Lutum } \\
\left(\mathrm{g} \mathrm{g}^{-1}\right)\end{array}$ & $\begin{array}{l}\text { Silt } \\
\left(\mathrm{g} \mathrm{g}^{-1}\right)\end{array}$ & $\begin{array}{l}\text { Leem } \\
\left(\mathrm{g} \mathrm{g}^{-1}\right)\end{array}$ & $\begin{array}{l}\text { M50 } \\
(\mu \mathrm{m})\end{array}$ & $\begin{array}{l}\text { Organische } \\
\text { stof }\left(\mathrm{g} \mathrm{g}^{-1}\right)\end{array}$ & $\begin{array}{l}\text { Droge bulk- } \\
\text { dichtheid }\left(\mathrm{gm}^{-3}\right)\end{array}$ \\
\hline 10156 & $15-25$ & 3,8 & 2,9 & 6,7 & 174 & 2,5 & 1,600 \\
\hline 10157 & $40-50$ & 0,9 & 0,0 & 0,9 & 177 & 0,4 & 1,803 \\
\hline 10158 & $75-85$ & 1,0 & 0,5 & 1,5 & 174 & 0,4 & 1,817 \\
\hline 10159 & $15-25$ & 2,6 & 3,7 & 6,3 & 175 & 2,4 & 1,634 \\
\hline 10160 & $40-50$ & 1,3 & 0,4 & 1,7 & 178 & 0,5 & 1,787 \\
\hline 10161 & $75-85$ & 0,8 & 0,9 & 1,7 & 177 & 0,3 & 1,836
\end{tabular}

Tabel B3-2 De Mualem-Van Genuchten-parameters voor de duplo monsters van de drie bemonsterde lagen en de gemeten doorlatendheid bij verzadiging ( $\left.K_{s, \text { meet }}\right)$ (Bakker et al., 2020).

\begin{tabular}{lllllllll} 
MIN & $\begin{array}{l}\text { Diepte } \\
(\mathrm{cm}-\mathrm{mv})\end{array}$ & $\begin{array}{l}\theta_{\mathrm{r}} \\
\left(\mathrm{cm}^{3} \mathrm{~cm}^{-3}\right)\end{array}$ & $\begin{array}{l}\theta_{\mathrm{s}} \\
\left(\mathrm{cm}^{3} \mathrm{~cm}^{-3}\right)\end{array}$ & $\begin{array}{l}\alpha \\
\left(\mathrm{cm}^{-1}\right)\end{array}$ & $\begin{array}{l}n \\
(-)\end{array}$ & $\begin{array}{l}\lambda \\
(-)\end{array}$ & $\begin{array}{l}K_{\mathrm{s}, \text { fit }} \\
\left(\mathrm{cm} \mathrm{d}^{-1}\right)\end{array}$ & $\begin{array}{l}K_{\mathrm{s}, \text { meet }} \\
\left(\mathrm{cm} \mathrm{d}^{-1}\right)\end{array}$ \\
\hline 10156 & $15-25$ & 0,074 & 0,427 & 0,01955 & 2,428 & 0,3199 & 18,9 & 88,5 \\
\hline 10157 & $40-50$ & 0,040 & 0,315 & 0,01664 & 4,174 & $-0,5433$ & 10,5 & 49,7 \\
\hline 10158 & $75-85$ & 0,026 & 0,361 & 0,01349 & 4,442 & 0,0761 & 9,8 & 93,4 \\
\hline 10159 & $15-25$ & 0,066 & 0,422 & 0,02084 & 2,216 & 0,5105 & 21,5 & 121,1 \\
\hline 10160 & $40-50$ & 0,040 & 0,318 & 0,01540 & 3,850 & $-0,3858$ & 4,8 & 47,7 \\
\hline
\end{tabular}

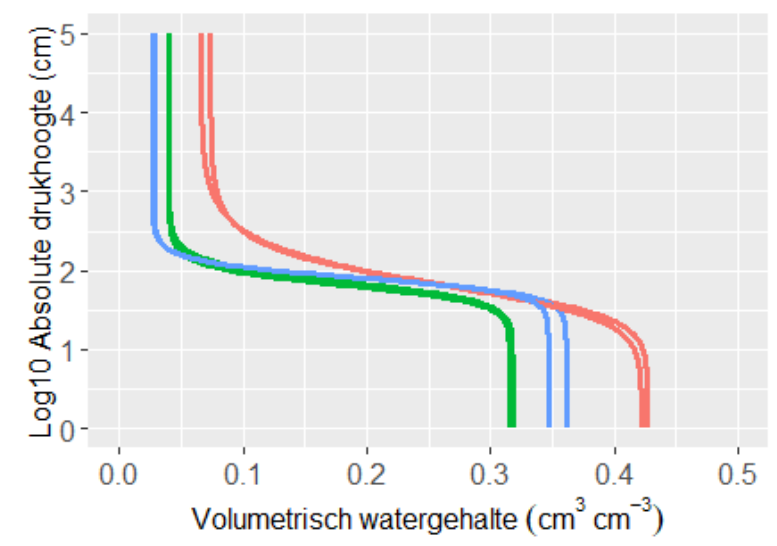

- Laag $1-\operatorname{Laag} 2-\operatorname{Laag} 3$

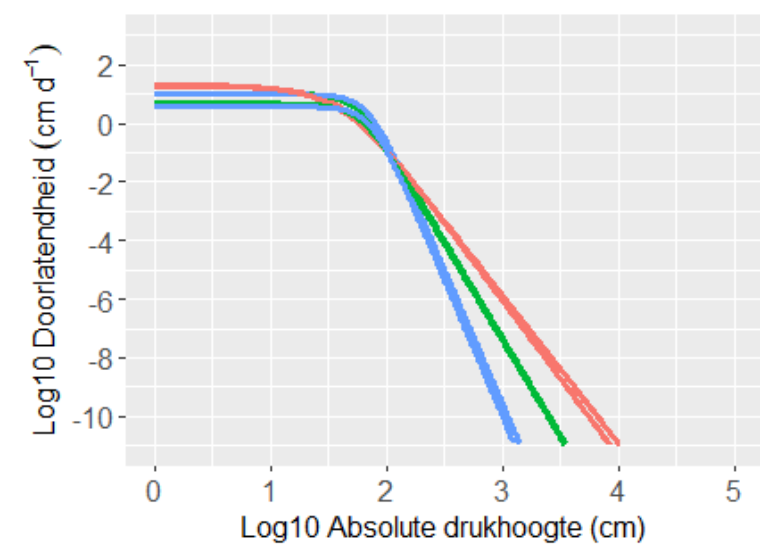

- Laag $1-\operatorname{Laag} 2-\operatorname{Laag} 3$

Figuur B3-1 (Links) waterretentie- en (rechts) doorlatendheidskarakteristieken voor de duplo monsters in drie lagen (laag 1: 15-25 cm - mv; laag 2: 40-50 cm -mv; laag 3: 75-85 cm-mv). De Mualem-Van Genuchten-parameters van deze curven zijn vermeld in Tabel Bx-2. 
Wageningen Environmental Research Postbus 47

6700 AA Wageningen

T 0317480700

www.wur.nl/environmental-research

Wageningen Environmental Research Rapport 3081

ISSN 1566-7197
De missie van Wageningen University \& Research is 'To explore the potential of nature to improve the quality of life'. Binnen Wageningen University \& Research bundelen Wageningen University en gespecialiseerde onderzoeksinstituten van Stichting Wageningen Research hun krachten om bij te dragen aan de oplossing van belangrijke vragen in het domein van gezonde voeding en leefomgeving. Met ongeveer 30 vestigingen, 6.500 medewerkers ( $5.500 \mathrm{fte}$ ) en 12.500 studenten behoort Wageningen University \& Research wereldwijd tot de aansprekende kennisinstellingen binnen haar domein. De integrale benadering van de vraagstukken en de samenwerking tussen verschillende disciplines vormen het hart van de unieke Wageningen aanpak. 


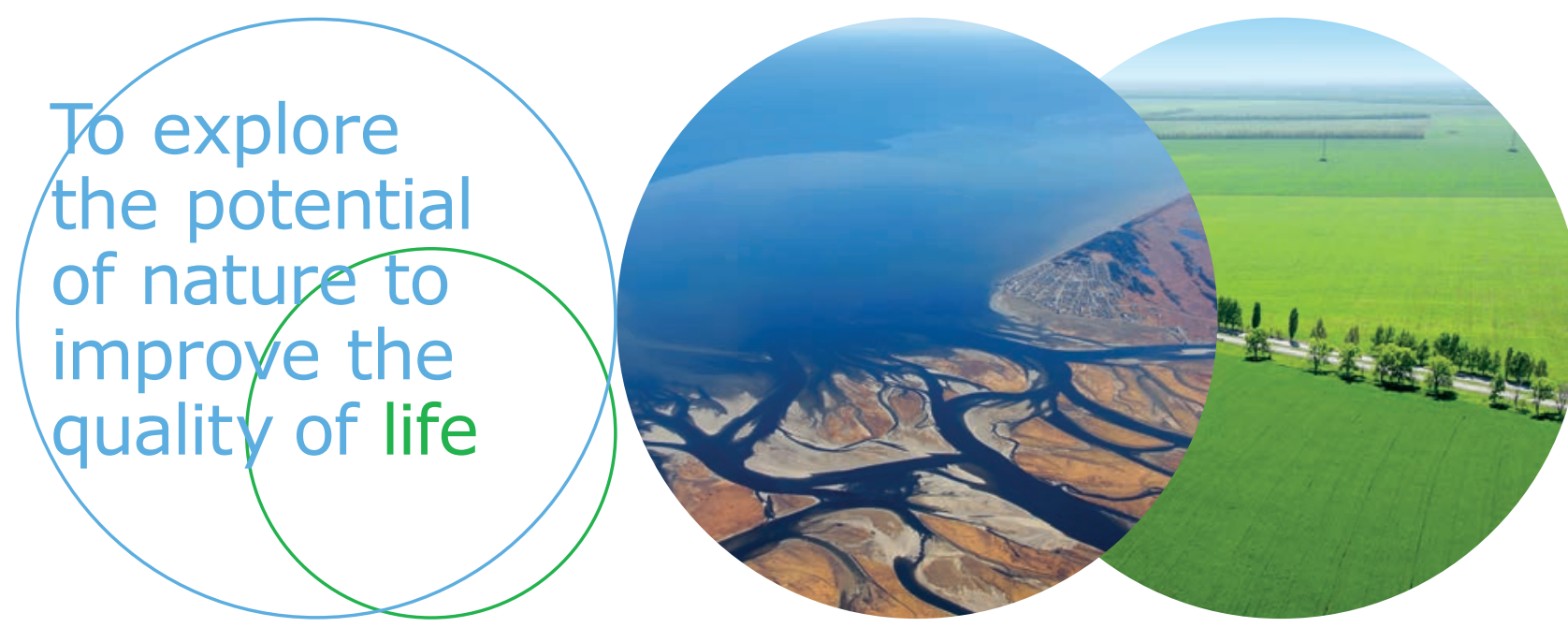

Wageningen Environmental Research Postbus 47

$6700 \mathrm{AB}$ Wageningen

T 317480700

www.wur.nl/environmental-research

Rapport 3081

ISSN 1566-7197
De missie van Wageningen University \& Research is 'To explore the potential of nature to improve the quality of life'. Binnen Wageningen University \& Research bundelen Wageningen University en gespecialiseerde onderzoeksinstituten van Stichting Wageningen Research hun krachten om bij te dragen aan de oplossing van belangrijke vragen in het domein van gezonde voeding en leefomgeving. Met ongeveer 30 vestigingen, 6.500 medewerkers ( $5.000 \mathrm{fte}$ ) en 12.500 studenten behoort Wageningen University \& Research wereldwijd tot de aansprekende kennisinstellingen binnen haar domein. De integrale benadering van de vraagstukken en de samenwerking tussen verschillende disciplines vormen het hart van de unieke Wageningen aanpak. 